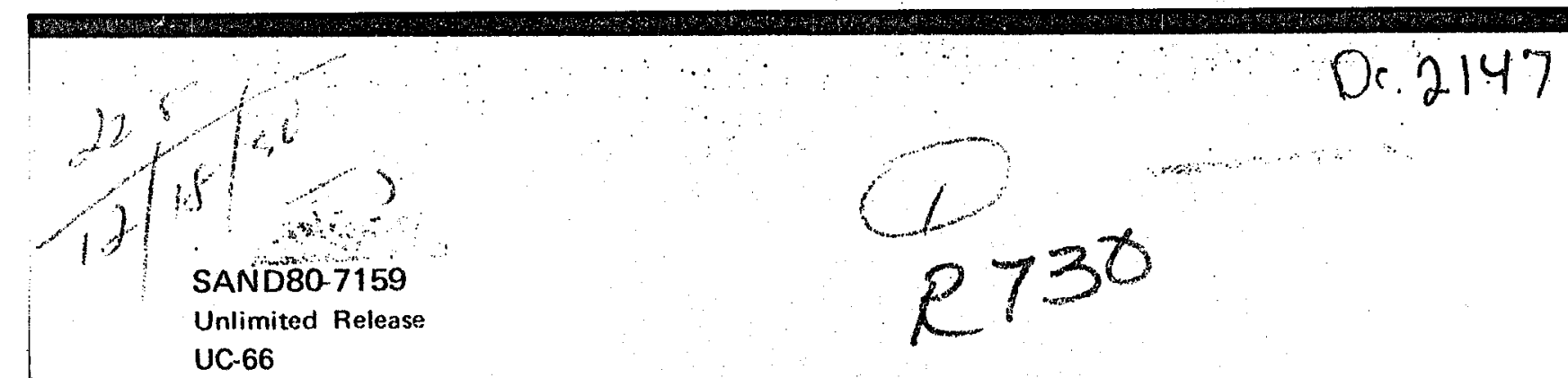

\title{
Strength and Ductility of Room-Dry \\ and Water-Saturated Igneous Rocks at Low Pressures and Temperatures to Partial Melting
}

Final Roport

M. Friedman, J. Handin, N. G. Higgs, J. R. Lantz, S. J. Bauer

Texas A\&M University, College Station, Texas 77843

Prepared by Sandia National Laboratories, Albuquerque, New Mexico 87185 and Livermore, California 94550 for the United States Department of Energy under Contract DE-AC04-76DPOO789

Printed November 1980

Prepared for Sandia National Laboratories, Albuquerque, NM under Contract No. 132242. 


\section{DISCLAIMER}

This report was prepared as an account of work sponsored by an agency of the United States Government. Neither the United States Government nor any agency Thereof, nor any of their employees, makes any warranty, express or implied, or assumes any legal liability or responsibility for the accuracy, completeness, or usefulness of any information, apparatus, product, or process disclosed, or represents that its use would not infringe privately owned rights. Reference herein to any specific commercial product, process, or service by trade name, trademark, manufacturer, or otherwise does not necessarily constitute or imply its endorsement, recommendation, or favoring by the United States Government or any agency thereof. The views and opinions of authors expressed herein do not necessarily state or reflect those of the United States Government or any agency thereof. 


\section{DISCLAIMER}

Portions of this document may be illegible in electronic image products. Images are produced from the best available original document. 
STRENGTH AND DUCTILITY OF ROOM-DRY AND WATER-SATURATED IGNEOUS ROCKS AT LOW PRESSURES AND TEMPERATURES TO PARTIAL MELTING

M. Friedman, J. Handin, N. G. Higgs, J. R. Lantz, and S. J. Bauer Center for Tectonophysics

Texas A\&M University

College Station, Texas 77843

(713) $845-3251$

FINAL REPORT

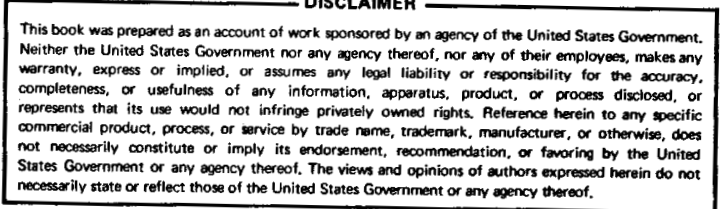

May 15, 1980

Contract No. 13-2242

Work Sponsored by Sandia Laboratories

Requester: J.L.Colp, Org. 4731

Contracting Representative: A. L. McKay, Org. 3721

Prepared for

Sandia Laboratories

Albuquerque, New Mexico

OISTBIEUTIEA OF THIS OOCURERT IS UALLRITEO 
List of Figures . . . . . . . . . . . . . . . . i i List of Tables . . . . . . . . . . . . . . . . . . . . . . . . . ABSTRACT . . . . . . . . . . . . . . . . . . 1 INTRODUCTION . . . . . . . . . . . . . . . 4 APPARATUS AND PROCEDURES . . . . . . . . . . . . . . . 5

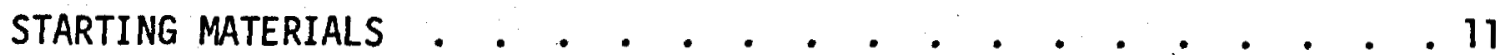
Mount Hood Andesite .. . . . . . . . . . . . . . 11 Charcoal Granodiorite. . . . . . . . . . . . . . . 11

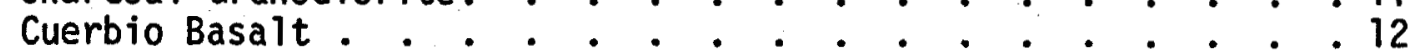
Newberry Rhyolite obsidian: . . . . . . . . . . 13

EXPERIMENTAL RESULTS. . . . . . . . . . . . . . 15

Crystalline Rocks . . . . . . . . . . . . . 15 Dry Experiments . . . . . . . . . . . . . 15

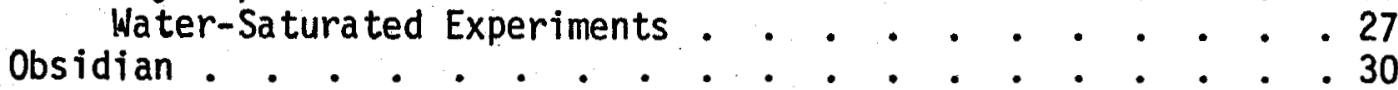
Short-Term Behavior. . . . . . . . . . . . . . 30 Time-Dependent Flow. . . . . . . . . . . . . . 35

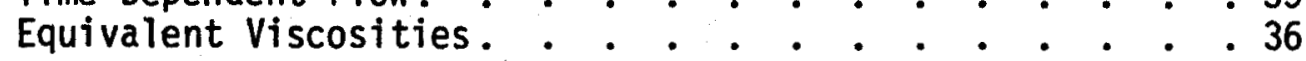

PETROFABRIC OBSERVATIONS . . . . . . . . . . . . . . 39 Macrofractures . . . . . . . . . . . . . . . . 39 Microfractures . . . . . . . . . . . . . . 40

Partial Melting. . . . . . . . . . . . . 49

BOREHOLE STABILITY . . . . . . . . . . . . . . . . . 55

Borehole Stresses . . . . . . . . . . . . . 55

Estimation of Borehole Stability $.0_{0} \cdot 0_{0} \cdot 0^{*} \cdot 61$ Dry Rocks . . . . . . . . . . . . 61 Water-Saturated Rocks . . . . . . . . . .70 Time-Effects . . . . . . . . . . . . . 74

CONCLUSIONS. . . . . . . . . . . . . . . . 78 ACKNOWLEDGMENTS • . . . . . . . . . . . . . 83 REFERENCES . . . . . . . . . . . . . . . . 84 
List of Figures

Figure

Page

1 High temperature triaxial cell............ 6

2 Schematic diagram of internal furnace . . . . . . 8

3 Stress-shortening curves for room-dry Mt. Hood Andesite - 19

$4 \quad$ Stress-shortening curves for room-dry Charcoal

Granodiorite.............. 20

5 Stress-shortening curves for room-dry Cuerbio Basalt. . . 21

$6 \quad$ Ultimate strength versus temperature for Mt. Hood

Andesite................ 22

$7 \quad$ Ultimate strength versus temperature for Charcoal

Granodiorite. .............. 23

8 Ultimate strength versus temperature for Cuerbio Basalt . 24

9 Stress-shortening curves for water-saturated rocks. . . 29

10 Stress-shortening curves for unconfined, dry, Newberry

Rhyolite Obsidian at temperatures to $800^{\circ} \mathrm{C}$. . . . . 32

11 Stress-shortening curves for Newberry Rhyolite Obsidian at $50 \mathrm{MPa}$-confining pressure and temperature between $700^{\circ}$ and $800^{\circ} \mathrm{C}$

12 Ultimate strength versus temperature for Newberry

Rhyolite Obsidian............... 34

13. Log strain rate versus $10 \mathrm{~g}$ steady-state flow stress for Newberry Rhyolite Obsidian between $700^{\circ}$ and $800^{\circ} \mathrm{C} \ldots 37$

14 Plot of angle $\theta$ between $\sigma_{1}$ and fault versus strain rate .41

15 Photomicrographs of deformed specimens......... 43

16 Photomicrographs of deformed specimens. . . . . . 45

17 Microfracture abundance versus temperature for dry Charcoal Granodiorite ................ 47

18 Microfracture abundance versus temperature for dry Mt.

Hood Andesite................ 48

19 Photograph of a partially melted specimen of Mt. Hood Andesite. ............... 50

20 Photomicrograph of flow in two glasses from partially melted Charcoal Granodiorite............. 51 
Figure

21 Photomicrographs of amber glass in Charcoal Granodiorite. . 52

22 Photomicrographs of partially melted Mt. Hood Andesite. . . 53

23 Radial and tangential stresses around a cylindrical hole. . 58

24 Assessment of borehole stability for dry Mt. Hood

Andesite. . . . . . . . . . . . . 6 64

25 Assessment of borehole stability for dry Charcoal

Granodiorite. ................66

26 Assessment of borehole stability for dry Cuerbio Basalt . . 67

27 Assessment of borehole stability for wet Mt. Hood

Andesite. . . . . . . . . . . . . 72

28 Assessment of borehole stability for wet Charcoal

Granodiorite................. 73

29 Transient creep data for crystalline rocks. . . . . . . 77

Table List of Tables Page

1 Experimental data for dry Mt. Hood Andesite ....... . 16

2 Experimental data for dry Charcoal Granodiorite . . . . . 17

3 Experimental data for dry Cuerbio Basalt. . . . . . . 18

4 Experimental data for water-saturated rocks ......28

5 Experimental data for Newberry Rhyolite Obsidian. . . . . 31

6 Electron microprobe analyses of two glasses from partially mel ted Mt. Hood Andesite and Charcoal Granodiorite. . . . . 54

7 Some in situ stress measurements in igneous rocks .....56

8 Borehole stresses $(\mathrm{MPa} / \mathrm{km}) \ldots \ldots \ldots 2$

$9 \quad$ Maximum depth for stable boreholes, dry rocks ......68

10 Transient creep parameters for granitic rocks .....76 
Energy extraction from magma requires stable boreholes at relatively shallow depths $(<10 \mathrm{~km})$ in rocks at temperatures approaching partial melting. Accordingly, the failure strengths, strains at failure, and associated deformation mechanisms are determined at temperatures to partial melting $\left(>1050^{\circ} \mathrm{C}\right.$ ) and a strain rate of $10^{-4} \mathrm{~s}^{-1}$ for (a) room-dry Mt. Hood Andesite, Cuerbio Basalt, and Charcoal Granodiorite at confining pressures of 0,50 , and $100 \mathrm{MPa}$, (b) $\mathrm{H}_{2} \mathrm{O}$-saturated specimens of these same crystalline rocks at zero effective confining pressure (pore and confining pressures of $50 \mathrm{MPa}$ ), and (c) room-dry Newberry Rhyolite Obsidian at 0 and $50-\mathrm{MPa}$ confining pressure. The strengths of the dry crystalline rocks are a nearly linear function of mean stress, and they decrease nearly linearly with increasing temperatures from $25^{\circ} \mathrm{C}$ to $800-900^{\circ} \mathrm{C}$. At higher temperatures the strengths decrease rapidly and vanish upon partial melting when the deformation becomes quasiviscous. The obsidian is stronger than the crystalline rocks at $600^{\circ} \mathrm{C}$ where glass softening begins and its strength goes to zero at about $800^{\circ} \mathrm{C}$. Water-weakening is evident only in the andesite. Its strength degrades dramatically between $850^{\circ}$ and $880^{\circ} \mathrm{C}$, at which temperature its ultimate strength is between 5 and $25 \mathrm{MPa}$ compared to an average dry strength of $75 \mathrm{MPa}$ at $1000^{\circ} \mathrm{C}$. Al1 rocks are brittle throughout the entire temperature range until melting or softening occurs. Shortenings at failure (ultimate strengths) are 3 percent or less in dry tests and $\leq 1$ percent in most wet ones.

Time-dependent flow characteristics are obtained for the dry obsidian through stress-relaxation tests at 0 and $50 \mathrm{MPa}, 10^{-4}$ to $10^{-6} \mathrm{~s}^{-1}$, 
and between $700^{\circ}$ and $800^{\circ} \mathrm{C}$ (i.e., in its glass-softening phase). Unconfined equivalent viscosities decrease from $3.4 \times 10^{11}$ at $700^{\circ} \mathrm{C}$ to about $3 \times 10^{10} \mathrm{~N} \cdot \mathrm{s} / \mathrm{m}^{2}$ at $800^{\circ} \mathrm{C}$. At $50 \mathrm{MPa}$, they decrease with increasing temperature along a slightly steeper slope, but the effect of the pressure increment is insignificant. A flow law of the type $e=A \exp (-Q / R T)$ $\left(\sigma_{1}-\sigma_{3}\right)^{n}$ fit the data between $700^{\circ}$ and $800^{\circ} \mathrm{C}$ with $A=2 \times 10^{13}$ (when $\sigma$ is in $\mathrm{MPa}$ and $e$ is $\mathrm{s}^{-1}$ ), $Q=380 \mathrm{~kJ} / \mathrm{mol}, \mathrm{n}=1.5$, and $\mathrm{R}$ is the gas constant. Our data on viscosities and $Q$ are in very good agreement with those of Murase and McBirney (1973) on the same obsidian.

The crystalline rocks tend to deform primarily by precursive microscopic extension fracturing and its coalescence into macroscopic faults. The abundance of load-induced fractures in dry specimens remains about constant, but thermal cracking increases with increasing temperature. Results from tests at $25^{\circ} \mathrm{C}$ on specimens that previousiy had been heated to $900-1000^{\circ} \mathrm{C}$ clearly show that the weakening of the unconfined dry specimens is due to the thermal cracking. Weakening of confined specimens, however, probably is due to an inherent temperature effect on the load-induced fracturing process. Each wet-specimen also fails along multiple macroscopic fractures or along a discrete fault. Weakening of the andesite is inferred to be due to hydration of Si-0 bonds which causes stress-corrosion cracking or a lowering of the melting point. Significant water-weakening of the andesite occurs in contrast to the other two crystalline rocks, apparently because its greater porosity (10-12 percent and assumed corresponding permeability) permits greater access of the $\mathrm{H}_{2} \mathrm{O}$ to internal solid surfaces.

In that the crystalline rocks remain brittle up to the temperatures 
of partial melting, they are very likely to remain drillable by conventional means at the highest temperatures to be encountered in the roofregions of buried magma chambers. Moreover, the penetration rate ought to increase as the magma body is approached because rock strength decreases with increasing temperature.

Instantaneous rock strength governs the stability of the borehole walls upon or shortly after drilling. Failure in compression would occur if stress differences between borehole pressure and the stresses in the walls of the borehole exceed the failure strength of the rock at a given mean pressure. Potential borehole failure at this stage could lead to stuck drill bits and possible loss of the hole. In general the maximum depth for stable boreholes increases with decreasing temperature, decreasing $\sigma_{h} / \sigma_{v}$ ratio, and for dry rocks with filled versus open boreholes. Furthermore, other factors being equal, boreholes in the granodiorite should remain stable to greater depths than those in basalt or andesite, with the andesite providing the least stable ones. In the most optimistic case, smooth, even unfilled boreholes in dry, impervious, fresh crystalline rock are apt to be stable over short time periods to depths $>10 \mathrm{~km}$ provided temperatures do not exceed $700^{\circ} \mathrm{C}$ and the $\sigma_{h} / \sigma_{v}$ ratio is 0.5 . Even the water-saturated andesite, which is water-weakened, would provide stable boreholes to $>10 \mathrm{~km}$ and temperatures to $880^{\circ} \mathrm{C}$ if the effective pressure was zero and $\sigma_{h} / \sigma_{v}$ is 1.0. On the other hand, unfilled boreholes in the andesite are apt to fail at only 1 to $2 \mathrm{~km}$ depth even at $25^{\circ}$, if $\sigma_{h} / \sigma_{v}$ is 2.0 . 


\section{INTRODUCTION}

Borehole stability is one of many severe engineering problems to be anticipated should attempts ever be made to recover directly the geothermal energy stored in magma chambers, as temperatures of the order of $1000^{\circ} \mathrm{C}$ are expectable. How strong are the rocks to be drilled in this hostile environment? Previous laboratory work is not very helpful because virtually all testing above $500^{\circ} \mathrm{C}$ has been done at either atmospheric pressure (Murrell and Chakravarty, 1973) or very high confining pressures of $400 \mathrm{MPa}$ or more (Handin, 1966; Carter, 1976; Carter and Kirby, 1978). What is needed is testing at high temperature but low confining pressure. Thus, under laboratory conditions that simulate the expectable natural environment of engineering concern, we are testing rock types that are likely candidates for drilling. Reported herein are the short-time ul timate strengths and ductilities determined at temperatures of $25^{\circ}$ to $1050^{\circ} \mathrm{C}$ and a strain rate of $10^{-4} \mathrm{~s}^{-1}$ of (a) room-dry Mt. Hood Andesite, Cuerbio Basalt, and Charcoal (St. Cloud Gray) Granodiorite at confining pressures of 0,50 , and $100 \mathrm{MPa}$, (b) water-saturated specimens of the same three rocks at zero effective pressure (both pore and confining pres: sures of $50 \mathrm{MPa}$ ), and (c) room-dry Newberry Rhyolite Obsidian at 0 and $50 \mathrm{MPa}$. These strengths are then compared with the stresses developed at the wall of a borehole in an elastic medium at the appropriate temperatures and mean pressures to assess the problem of borehole stability. 


\section{APPARATUS AND PROCEDURES}

Some of the triaxial compression tests have been done in a screwdriven machine, similar to that designed by Heard (1963), at strain rates of $10^{-4}$ and $10^{-7} / \mathrm{s}$ on 0.9 by $2.0-\mathrm{cm}$ specimens. Others, including all at temperatures above $400^{\circ} \mathrm{C}$, have been carried out in the new apparatus (Figure 1) briefly described below.

Cylindrical specimens, $2 \mathrm{~cm}$ in diameter and $4 \mathrm{~cm}$ in length, are axially loaded in a simple four-pole hydraulic press, driven by a variablespeed, constant-displacement, duplex oil pump so as to shorten specimens at constant axial strain rates of $10^{-4}$ or $10^{-6} / \mathrm{s}$. Force (up to $1 \mathrm{MN}$ ) is measured by a Baldwin CXX load-cell hooked to an X-Y recorder. Displacement is measured by a DCDT hooked to the same recorder.

The confining pressure of argon up to $300 \mathrm{MPa}$ is generated by an intensifier driven by an air pump and charged by an oil-gas separater driven by a second air pump. It is measured by a precision Heise gauge and regulated by a Brown strip-chart recorder.

The triaxial cell, similar in design to that of Goetze (1971), with an inside diameter of $3.8 \mathrm{~cm}$ and an outside diameter of $16.5 \mathrm{~cm}$, is made of 4340 steel, drawn to a hardness of Rockwell $34 \mathrm{C}$ for optimum toughness. Inside the cell the specimen is jacketed in a thin-walled copper sleeve and surrounded by the internal furnace. This furnace consists of two independently powered coils of Kanthal wire separated by a distance equal to the length of the specimen, and embedded in Norton EA 162 al umina and Sauereisen No. 78 electric-resistor cement prior to wrapping with Fiberfrax, refractory, insulating paper to the maximum diameter. The absence of furnace windings in the central region serves to flatten previously 


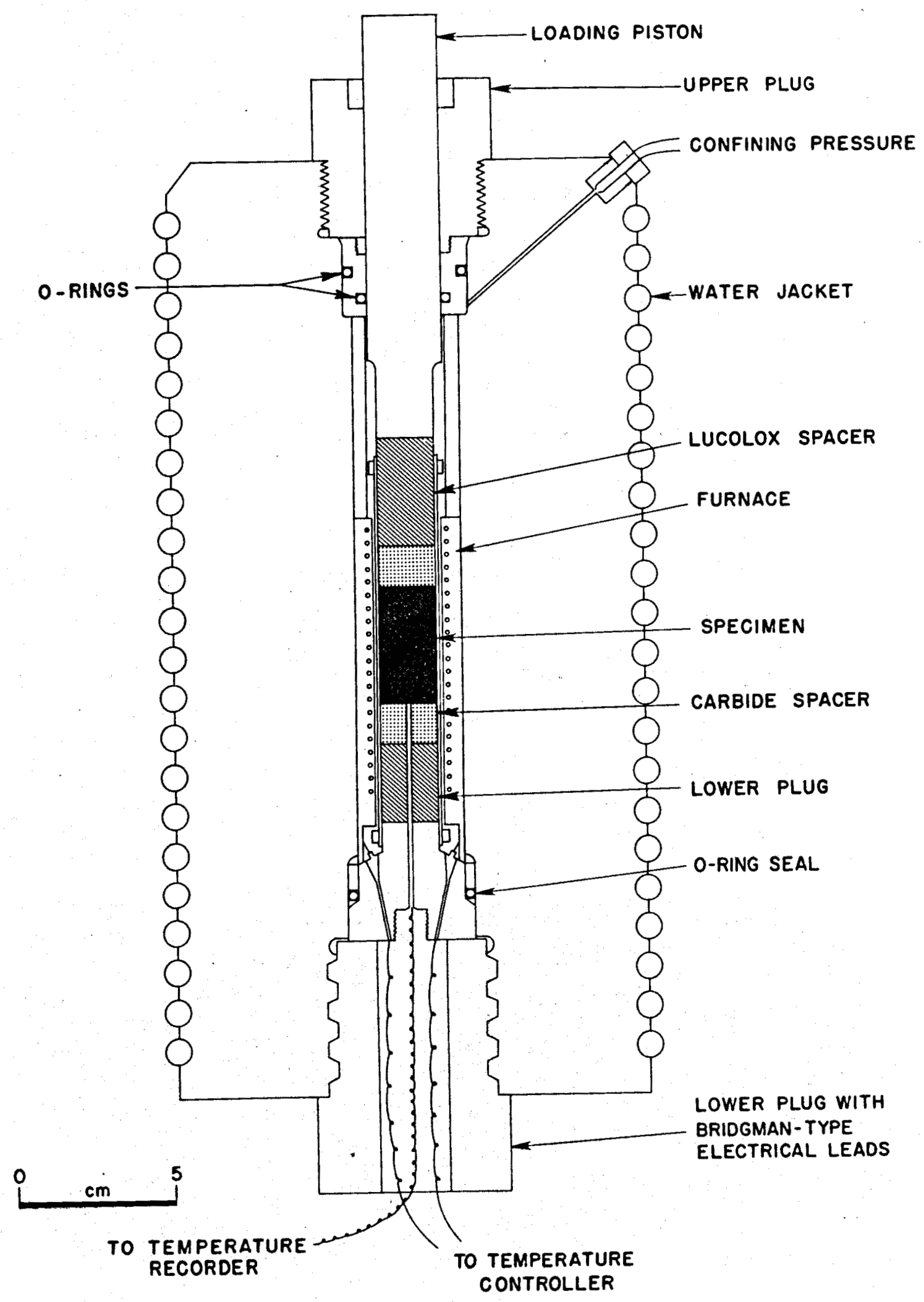

Figure 1. High-temperature trixial cell. 
convex temperature profiles, related to the low conductivity of the sample. By adjusting the power distribution between the upper and lower windings, severe thermal gradients caused by convection in the gap between the furnace and the specimen assembly are subdued. For unconfined tests, nearly flat temperature profiles are achieved by dissipating only $40 \%$ of the total power to the upper furnace coil. For confined tests, convection in the dense argon confining-medium has been a bigger problem, but this has been overcome by infilling the annulus between the furnace wall and specimen with boron-nitride powder, an inert, non-abrasive material, combining excellent dielectric characteristics with good thermal. conductivity, and effectively eliminating convection. Temperature is measured on the specimen by a thermocouple inserted through a hole in the lower plug and reguiated by a West stepless controller. Furnace power is fed through Bridgman-type, insulated cones. Temperature differences along the length of the specimen are held to as small as $30^{\circ} \mathrm{C}$ at $1000^{\circ} \mathrm{C}$, and temperature measurements are accurate to $\pm 5^{\circ} \mathrm{C}$ (Figure 2 ).

The cell is cooled externally by a water jacket, and loss of heat through the upper loading piston and lower plug is reduced by lucalox spacers, which are excellent thermal insulators, but which also have adequate compressive strengths at the temperatures of interest. Seals on the moving piston and lower closure can then be made by ordinary rubber 0 -rings.

Each dry test is done at a constant confining pressure of 0,50 , or $100 \mathrm{MPa}$, a temperature between $25^{\circ}$ and $1050^{\circ} \mathrm{C}$, and a strain rate of $10^{-4} \mathrm{~s}^{-1}$. True stress-strain curves are derived from the force-displacement record. Axial differential stress at each increment of axial strain is calculated by dividing the recorded differential force by the area of the specimen, corrected by assuming Poisson's ratio of 0.25 in the elastic range and 


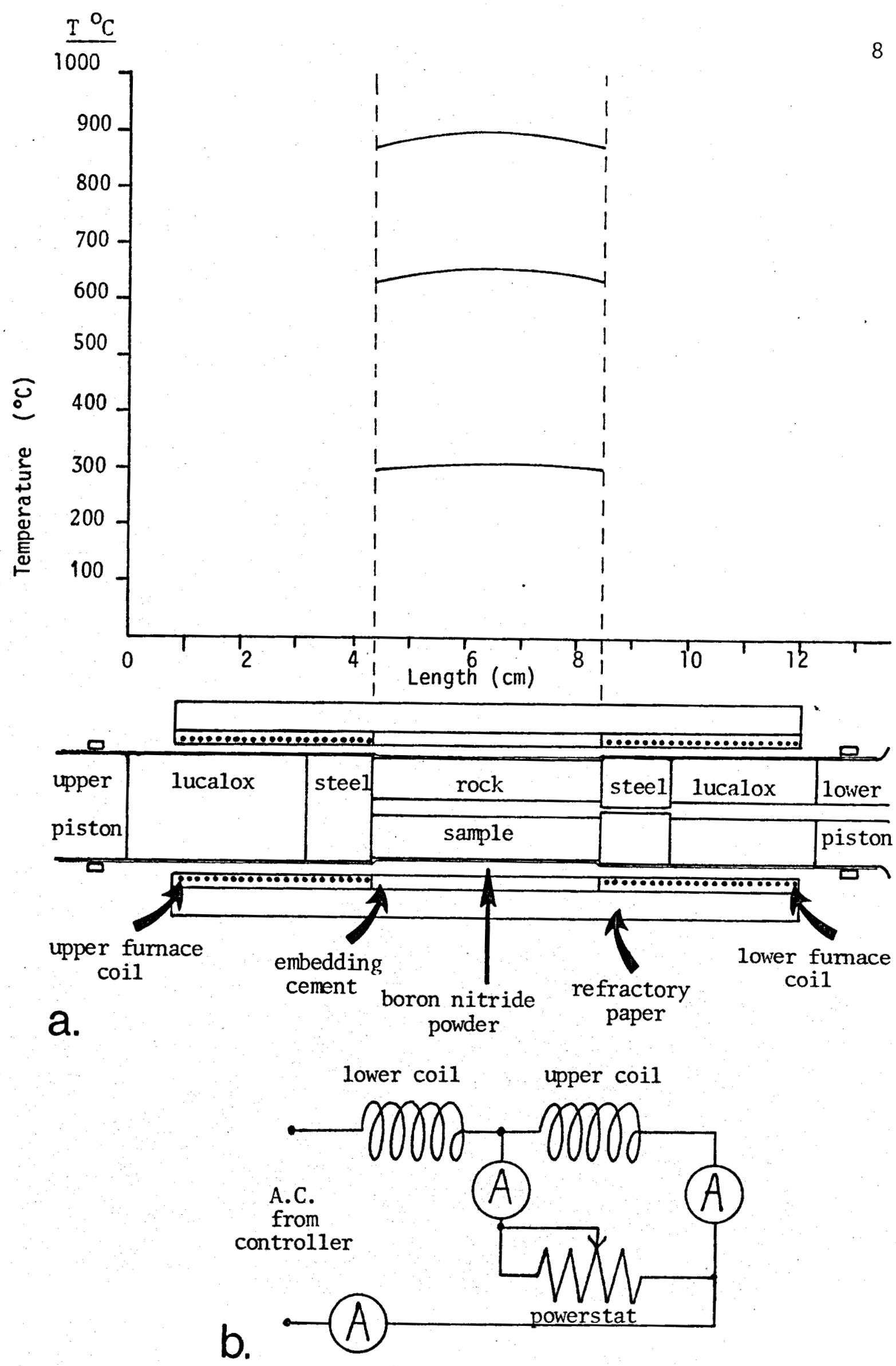

Figure 2. Schematic diagram (a) shows modified furnace design with accompanying axial temperature profiles for an unconfined test with an air gap between furnace and specimen assembly. Boron nitride powder fills the gap when test is to be made at confining pressure. In (b) a circuit diagram illustrates how total power is distributed between upper and lower furnace coils. 
volume conservation and homogeneous deformation in the inelastic range. Conventional strain is calculated by dividing the change in length by the original length, the displacement record having been corrected for elastic distortion of the apparatus, and expressed as percent shortening. The accuracies of stress, strain, and confining pressure are 2 to 3 percent.

In the triaxial compression test, the principal stresses are $\sigma_{1}>\sigma_{2}$ $=\sigma_{3}=p_{C}$, where $p_{c}$ is confining pressure and compressive stresses are counted positive. Later on, we shall use the laboratory data to predict failure of the borehole where $\sigma_{1}>\sigma_{2}>\sigma_{3}$, and we shall assume that ultimate compressive strength $\left(\sigma_{1}-\sigma_{3}\right)$, at failure, is a function only of mean stress, $\sigma_{m}=\left(\sigma_{1}+\sigma_{2}+\sigma_{3}\right) / 3$, and temperature. Thus, for each test we compute $\left(\sigma_{1}-\sigma_{3}\right)$ and $\sigma_{m}$ and list them together with the total shortening at macroscopic failure that serves as a measure of ductility (Tables 1-5). Also listed is the angle $\theta$ between the load axis $\left(\sigma_{1}\right)$ and the macroscopic fault, as measured with a contact goniometer outside the copper jacket. "Shattered" specimens have failed by multiple faulting, and $\theta$ cannot be determined.

For the water-saturated tests, each specimen is jacketed with excess water in thin-walled copper tubing, and is placed within the internal furnace in the pressure cell. The confining pressure and pore pressure are elevated, e.g., to 50 and $45 \mathrm{MPa}$, respectively. The $5 \mathrm{MPa}$ difference helps to drive water into pores and cracks and helps to keep it out of the interface between rock and jacket. Temperature is then elevated to test conditions at about $10^{\circ} \mathrm{C} \mathrm{min}^{-1}$ and the pore pressure is adjusted to $50 \mathrm{MPa}$. Use of spacers and pistons with a central borehole make these 
drained tests: If during an experiment the pore space is fully saturated and the pore pressure is equilibrated throughout the system, then the fluid pressure in the specimen is truly registered by the external gauge; and when the internal pore pressure, $p_{p}$, equals the external confining pressure, $p_{c}$, the effective confining pressure, $p_{e}$, is zero. If the effect of the fluid pressure is purely mechanical, the mechanical properties should then be the same as those measured for the dry rock at $p_{c}=0$. If the rock is not fully saturated and/or the permeability is very low, the true value of the pore pressure may be unknown, and the effective confining pressure may not be zero. Pore water is pumped into a specimen through a hole in the top piston; thus visual evidence of water at the lower end, at least confirms pervasion. 


\section{STARTING MATERIALS}

Mount Hood Andesite

Our sample was collected from a Recent flow, located just below the parking lot of Timberline Lodge on the south slope of Mount Hood. The block is pink and porphyritic with an aphanitic groundmass.. Porosity varies from 10 to $12 \%$. Phenocrysts comprise about $40 \%$ of the rock, $30 \%$ being plagioclase, $5 \%$ pyroxene, and about $1 \%$ each of hornblende, olivine, and magnetite. The feldspars are zoned, twinned labradorite, and along with the other phenocrysts, are conspicuously fractured. The long axes of the phenocrysts range up to $5 \mathrm{~mm}$; overall they are randomly oriented, although in small domains they often show parallel alignment. Microfractures are confined to the phenocrysts, and none was observed to transect both phenocrysts and groundmass. The microfractures are randomly oriented, and the average number of microfractures per $\mathrm{mm}$ is less than 1 in the groundmass and about 7 in the phenocrysts.

The groundmass consists of small crystals $(<1 \mathrm{~mm})$ of lath-shaped feldspar, dispersed magnetite, and a small amount of interstitial glass. It completely envelopes the phenocrysts. This nearly holocrystalline groundmass should serve as the load-bearing framework that controls the gross mechanical behavior of the rock. A chemical analysis is given by Murase and McBirney (1973) who also list liquidus temperatures of $1100^{\circ} \mathrm{C}$ for pyroxene, $1240^{\circ} \mathrm{C}$ for plagioclase, and $1210^{\circ} \mathrm{C}$ for the opaque oxides.

\section{Charcoal Granodiorite}

This rock is properly known as the St. Cloud Gray Granodiorite of 
Precambrian age from St. Cloud, Minnesota; "Charcoal" is its trade name. Our sample was purchased from the Cold Springs Granite Co. in Minnesota. It is one of the rocks adopted as standard by the U.S. Bureau of Mines (Krech et al., 1974). Its modal composition is: $38 \%$ labradorite, $26 \%$ orthoclase, $21 \%$ quartz, $12 \%$ hornblende and $5 \%$ biotite. Grain size ranges from < 0.1 to $10.0 \mathrm{~mm}$ and averages about $2 \mathrm{~mm}$. Quartz crystals are free of deformation lamellae; but $49 \%$ exhibit undulose extinction, $43 \%$ are polygonized, and $12 \%$ are undeformed. Some $67 \%$ contain healed fractures, and $21 \%$ contain fresh fractures. The feldspars are all twinned and nearly all contain some fractures. Overall, however, the average number of microfractures per $\mathrm{mm}$ is less than 1 .

There is a fracture anisotropy in this rock. Experimentally induced tensile fractures are controlled by pre-existing arrays of microfractures; ultrasonic velocity is minimum, and attenuation is maximum perpendicular to the plane of fracture anisotropy (Friedman and Bur, 1974). All our test specimens are loaded perpendicular to this plane. Porosity is less than $0.1 \%$.

Cuerbio Basalt

A large block of the Cuerbio Basalt of Early Pleistocene age was collected from the lower of two flows exposed in a roadcut along U.S. Highway 85 , near the top of La Bajada Hill, south of La Cienega, New Mexico. The specimen contains some macroscopic, elongated vesicles up to $2 \mathrm{~cm}$ long. Sawed slabs from the block were $X$-rayed at Sandia Laboratories by Dr. E. J. Graeber and his associate, so that we could core our specimens from domains free of the larger vesicles. This approach worked successfully, and the few small vesicles $(<1.0 \mathrm{~mm})$ exposed at the surface 
of some cylinders were filled with a high-temperature cement to prevent jacket failure. The reproducibility and consistent trends of the experimental data attest to the success of this approach. Porosity of test specimens ranges between 5 and $8 \%$.

The basalt is dark gray and it contains an aphanitic groundmass, phenocrysts, and vesicles, both with maximum lengths of about $1 \mathrm{~mm}$. Thinsection analyses reveal that the larger phenocrysts are composed of $80 \%$ euhedral, fractured olivine, $17 \%$ cleaved pyroxene, and $4 \%$ twinned and fractured feldspar; in aggregate these phenocrysts compose $14 \%$ of the rock. The groundmass $(86 \%)$ is holocrystalline and consists of microphenocrysts of olivine and pyroxene $(<0.1 \mathrm{~mm})$, magnetite $(<0.06 \mathrm{~mm})$, and lath-shaped feldspars (up to $0.35 \mathrm{~mm}$ ). These comprise $10 \%, 10 \%$, and $80 \%$ of the groundmass, respectively. Microscopically, the rock shows a flow layering manifest by the dimensional alignment of feldspar laths in the groundmass and the larger olivine phenocrysts. All our specimens are loaded parallel to this planar anisotropy.

Newberry Rhyolite Obsidian

Our sample was collected from the north end of the Big Obsidian Flow along the trail southeast of Paulina Lake, Newberry Caldera, Oregon. The block contains flow banding which locally produces a planar anisotropy and complicates the coring of perfect, right-circular cylinders for experiments. Microscopically, this rock consists entirely of a clear, black glass which completely envelope minute crystals of feldspar. The crystallites are strongly oriented dimensionally and reflect local, primary flow of lava prior to freezing. This fabric cannot be related to the experimental deformation; accordingly, petrofabric studies are macroscopic. 
A specimen deforms by either brittle fracture or by uniform flow with no macroscopic manifestation except barrelling. Data on chemical composition, viscosity, and other physical properties are given by Murase and McBirney (1973). 


\section{EXPERIMENTAL RESULTS}

Crystalline Rocks

Dry Experiments. Data sets for the instantaneous failure strength and strain of room-dry Mt. Hood Andesite, Charcoal Granodiorite, and Cuerbio Basalt, shortened at confining pressures of 0,50 , and $100 \mathrm{MPa}$, temperatures to $1000^{\circ} \mathrm{C}$, and a strain rate of $10^{-4} / \mathrm{s}$, are given in Tables 1, 2, and 3, and corresponding stress-strain curves appear in Figures 3, 4, and 5. These data reveal the following significant facts.

(1) The reproducibility of data on strength and shortening at failure is reasonably good for specimens deformed under similar conditions and for specimens of different size deformed under the same conditions, but in a different apparatus (e.g., Table 2, specimens $T 1$ and M3).

(2) The failure strengths of all three rocks decrease with increasing temperature at constant confining pressure and increase with increasing confining pressure at constant temperature (Figures 6,7 , and 8 ). The average strength-reduction of the andesite is essentially linear from 125 $\mathrm{MPa}$ at $25^{\circ} \mathrm{C}$ to $78 \mathrm{MPa}$ at $1000^{\circ}$ unconfined, and from $290 \mathrm{MPa}$ at $25^{\circ}$ to 200 $\mathrm{MPa}$ at $900^{\circ} \mathrm{C}$, at $50-\mathrm{MPa}$ confining pressure, or 1.2 and $3.3 \mathrm{MPa} / 25^{\circ} \mathrm{C}$. This strength reduction is more dramatic at $100 \mathrm{MPa}-$ confining pressure, i.e., $14 \mathrm{MPa} / 25^{\circ} \mathrm{C}$ between 700 and $1000^{\circ} \mathrm{C}$. Strength reductions for the granodiorite are larger than those for the andesite at each confining pressure, i.e., $11 \mathrm{MPa} / 25^{\circ} \mathrm{C}$ at $50 \mathrm{MPa}$ and $27 \mathrm{MPa} / 25^{\circ} \mathrm{C}$ at $100 \mathrm{MPa}$. Unconfined, the reduction in non-linear from $350 \mathrm{MPa}$ at $25^{\circ} \mathrm{C}$ to $35 \mathrm{MPa}$ at $1000^{\circ} \mathrm{C}$. The strength reduction for the basalt is also nearly linear to about $900^{\circ} \mathrm{C}$; gradients are $30 \mathrm{MPa} / 25^{\circ} \mathrm{C}$ at $100,8 \mathrm{MPa} / 25^{\circ} \mathrm{C}$ at $50-\mathrm{MPa}$ confining pressure 
TABLE 1. EXPERIMENTAL DATA FOR ROOM-DRY MOUHT HOOD ANDESITE

\begin{tabular}{|c|c|c|c|c|c|c|}
\hline $\begin{array}{c}\text { SPEC IMEN } \\
\text { NO. }\end{array}$ & $\begin{array}{l}\text { CONFINING } \\
\text { PRESSURE } \\
\text { (MPa) }\end{array}$ & $\begin{array}{l}\text { TEMP. } \\
\left({ }^{\circ} \mathrm{C}\right)\end{array}$ & $\begin{array}{l}\text { MEAN } \\
\text { STRESS } \\
\text { (MPa) }\end{array}$ & $\begin{array}{c}\text { ULTIMATE } \\
\text { STRENGTH } \\
(\mathrm{MPa})\end{array}$ & $\begin{array}{c}\text { SHORTENING } \\
\text { AT FAILURE } \\
(\%)\end{array}$ & $\begin{array}{l}\text { COMMENTS }^{a} \\
\text { FAULT ANGLE } \\
\left(\theta^{\circ}\right)\end{array}$ \\
\hline 20 & 0 & 25 & 50 & 150 & 1.1 & $s$ \\
\hline 21 & 0 & 25 & 30 & 100 & 1.1 & $s$ \\
\hline $481^{b}$ & 0 & 25 & 35 & 110 & 0.3 & $S$ \\
\hline $482^{b}$ & 0 & 25 & 30 & 90 & 0.8 & $s$ \\
\hline $483^{b}$ & 0 & 25 & 40 & 115 & 1.3 & 23 \\
\hline 493 & 0 & 400 & 50 & 145 & 1.3 & $s$ \\
\hline 496 & 0 & 400 & 35 & 110 & 1.2 & $s$ \\
\hline 499 & 0 & 400 & 35 & 105 & 1.2 & 23 \\
\hline $503^{b}$ & 0 & 400 & 35 & 110 & 1.0 & $s$ \\
\hline $507^{b}$ & 0 & 400 & 45 & 135 & 1.1 & 30 \\
\hline 36 & 0 & 700 & 40 & 115 & 1.0 & $25, \mathrm{~s}$ \\
\hline 37 & 0 & 700 & 35 & 100 & 0.9 & $S$ \\
\hline 8 & 50 & 25 & 155 & 320 & 2.3 & 27 \\
\hline 225 & 50 & 25 & 135 & 250 & 3.2 & $s$ \\
\hline $27^{b}$ & 50 & 25 & 125 & 220 & 6.8 & 34 \\
\hline $28^{b}$ & 50 & 25 & 125 & 220 & 6.9 & 32 \\
\hline 9 & 50 & 400 & 125 & 230 & 2.7 & 32 \\
\hline 16 & 50 & 400 & 150 & 305 & 1.8 & 32 \\
\hline 31 & 50 & 700 & 130 & 235 & 0.9 & I \\
\hline 34 & 50 & 700 & 130 & 235 & 1.6 & I \\
\hline 84 & 0 & 1000 & 30 & 85 & 1.5 & s \\
\hline 85 & 0 & 1000 & 25 & 75 & 1.5 & S \\
\hline 97 & 50 & 1000 & 85 & 110 & 1.4 & $s$ \\
\hline $123^{c}$ & 50 & 930 & 105 & 165 & 1.6 & \\
\hline $123^{c}$ & 50 & 900 & 115 & 195 & 3.5 & \\
\hline $123^{c}$ & 50 & 880 & 115 & 195 & 5.4 & \\
\hline $125^{d}$ & 50 & 25 & 180 & 390 & 2.1 & 32 \\
\hline 128 & 50 & 25 & 140 & 275 & 2.0 & 32 \\
\hline $221^{e}$ & 0 & 25 & 30 & 90 & 1.7 & $s$ \\
\hline $223^{f}$ & 0 & 25 & 40 & 120 & 1.5 & $S$ \\
\hline $226^{9}$ & 50 & 25 & 155 & 315 & 2.5 & 29 \\
\hline 258 & 100 & 720 & 230 & 395 & 2.2 & 30 \\
\hline 271 & 100 & 700 & 255 & 460 & 3.0 & $s$ \\
\hline 256 & 100 & 960 & 210 & 330 & 3.6 & $s$ \\
\hline 269 & 100 & 1000 & 190 & 275 & 3.2 & $32, \mathrm{~s}$ \\
\hline
\end{tabular}

a. $S$ = shattered ( 2 or more fractures or faults), $I=$ incipient fault.

b. Strain rate is $10^{-7} \mathrm{~s}^{-1}$.

c. Specimen work-hardened during temperature decrease.

d. Specimen 125 was heated to $930^{\circ} \mathrm{C}$ at $10^{\circ} \mathrm{C} / \mathrm{min}$, cooled, and then deformed at $25^{\circ} \mathrm{C}$ and 50 MPa.

e. Unconfined specimen heated to $905^{\circ} \mathrm{C}$ at $1.5^{\circ} \mathrm{C} / \mathrm{min}$, cooled, and then deformed at $25^{\circ} \mathrm{C}$.

f. Unconfined specimen heated to $1000^{\circ} \mathrm{C}$ at $1.5^{\circ} \mathrm{C} / \mathrm{min}$, cooled, and then deformed at $25^{\circ} \mathrm{C}$.

g. Unconfined specimen heated to $1000^{\circ} \mathrm{C}$ at $1.5^{\circ} \mathrm{C} / \mathrm{min}$, cooled and then deformed at $25^{\circ} \mathrm{C}$ and $50 \mathrm{MPa}$. 
TABLE 2. EXPERIMENTAL DATA FOR ROOM-DRY CHARCOAL GRANODIORITE

\begin{tabular}{|c|c|c|c|c|c|c|}
\hline $\begin{array}{l}\text { SPECIMEN } \\
\text { NO. }\end{array}$ & $\begin{array}{l}\text { CONFINING } \\
\text { PRESSURE } \\
\text { (MPa) }\end{array}$ & $\begin{array}{l}\text { TEMP } \\
\left({ }^{\circ} \mathrm{C}\right)\end{array}$ & $\begin{array}{l}\text { MEAN } \\
\text { STRESS } \\
\text { (MPa) }\end{array}$ & $\begin{array}{l}\text { ULTIMATE } \\
\text { STRENGTH } \\
\text { (MPa) }\end{array}$ & $\begin{array}{c}\text { SHORTENING } \\
\text { AT FAILURE } \\
(\%)\end{array}$ & $\begin{array}{l}\text { COMMENTS, }{ }^{a} \\
\text { FAULT ANGLE } \\
\left(\theta^{\circ}\right)\end{array}$ \\
\hline 22 & 0 & 25 & 120 & 360 & 0.8 & $s$ \\
\hline 24 & 0 & 25 & 115 & 340 & 0.6 & $s$ \\
\hline 38 & 0 & 400 & 40 & 115 & 1.0 & $s$ \\
\hline 44 & 0 & 400 & 40 & 115 & 0.8 & $s$ \\
\hline 511 & 0 & 400 & 60 & 175 & 1.3 & $s$ \\
\hline 512 & 0 & 400 & 60 & 175 & 1.1 & 18,5 \\
\hline $513^{b}$ & 0 & 400 & 55 & 165 & 1.1 & $s$ \\
\hline $514^{b}$ & 0 & 400 & 55 & 160 & 1.1 & $s$ \\
\hline 564 & 50 & 25 & 270 & 665 & 2.1 & 29 \\
\hline$\pi$ & 50 & 25 & 255 & 620 & 1.7 & $s$ \\
\hline M3 & 50 & 25 & 260 & 630 & 1.8 & 35 \\
\hline T2 & 50 & 400 & 220 & 510 & 1.4 & 27 \\
\hline 18 & 50 & 400 & 220 & 520 & 1.5 & $s$ \\
\hline 233 & 50 & 400 & 245 & 580 & 1.4 & $s$ \\
\hline 236 & 50 & 400 & 235 & 560 & 1.4 & 27 \\
\hline 45 & 50 & 400 & 230 & 535 & 1.5 & $s$ \\
\hline 46 & 0 & 700 & 15 & 45 & 1.2 & $s$ \\
\hline 47 & 0 & 700 & 25 & 70 & 1.2 & 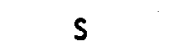 \\
\hline 231 & 50 & 700 & 205 & 465 & 2.0 & $27, S$ \\
\hline 232 & 50 & 700 & 180 & 390 & 1.8 & 29,5 \\
\hline 51 & 0 & $>1050$ & 0 & 0 & 27.0 & PM \\
\hline 86 & 0 & 1000 & 15 & 40 & 1.7 & $30, \mathrm{~s}$ \\
\hline 87 & 0 & 1000 & 10 & 30 & 1.9 & $30, \mathrm{~S}$ \\
\hline 118 & 50 & 1000 & 85 & 100 & 1.7 & s \\
\hline 119 & 50 & 930 & 135 & 255 & 1.9 & $s$ \\
\hline 132 & 50 & 1000 & 140 & 275 & 1.8 & 36 \\
\hline $133^{c}$ & 50 & 25 & 260 & 635 & 1.5 & 30 \\
\hline $216^{d}$ & 0 & 25 & 20 & 55 & 1.8 & $s$ \\
\hline $217^{e}$ & 0 & 25 & 20 & 60 & 2.2 & s \\
\hline $218^{e}$ & 0 & 25 & 20 & 60 & 1.8 & 5 \\
\hline $227^{9}$ & 50 & 25 & 235 & 560 & 2.5 & 27 \\
\hline 238 & $\overline{100}$ & 700 & 305 & 615 & 1.9 & 26 \\
\hline 239 & 100 & 700 & 320 & 655 & 1.9 & $27, S$ \\
\hline 247 & 100 & 885 & 250 & 445 & 2.2 & 31 \\
\hline 257 & 100 & 965 & 205 & 315 & 2.0 & $s$ \\
\hline
\end{tabular}

a. $S=$ shattered ( 2 or more fractures [or faults]). PM = partial melting.

b. Strain rate is $10^{-7} \mathrm{sec}^{-1}$.

c. Confined specimen heated at $10^{\circ} \mathrm{C} / \mathrm{min}$ to $1000^{\circ} \mathrm{C}$ and then deformed at $25^{\circ} \mathrm{C}$ and $50 \mathrm{MPa}$ confining pressure.

d. Unconfined specimen heated to $1000^{\circ} \mathrm{C}$ at $10^{\circ} \mathrm{C} / \mathrm{min}$ and then deformed at $25^{\circ} \mathrm{C}$, unconfined.

e. Unconfined specimens heated to $900^{\circ} \mathrm{C}$ at $1.5^{\circ} \mathrm{C} / \mathrm{min}$ and then deformed at $25^{\circ} \mathrm{C}$, unconfined.

g. Unconfined specimen heated to $1000^{\circ} \mathrm{C}$ at $1.5^{\circ} \mathrm{C} / \mathrm{min}$, cooled and then deformed at $25^{\circ} \mathrm{C}$ and $50 \mathrm{MPa}$. 
TABLE 3. EXPERIMENTAL DATA FOR ROOM-DRY CUERBIO BASALT

\begin{tabular}{|c|c|c|c|c|c|c|}
\hline $\begin{array}{c}\text { SPECIMEN } \\
\text { NO. }\end{array}$ & $\begin{array}{l}\text { CONF INING } \\
\text { PRESSURE } \\
\text { (MPa) }\end{array}$ & $\begin{array}{l}\text { TEMP. } \\
\left({ }^{\circ} \mathrm{C}\right)\end{array}$ & $\begin{array}{l}\text { MEAN } \\
\text { STRESS } \\
\text { (MPa) }\end{array}$ & $\begin{array}{l}\text { ULTIMATE } \\
\text { STRENGTH } \\
(\mathrm{MPa}) .\end{array}$ & $\begin{array}{l}\text { SHORTENING } \\
\text { AT FAILURE } \\
(\%)\end{array}$ & $\begin{array}{l}\text { COMMENTS }{ }^{\mathrm{a}}{ }^{2} \\
\text { FAULT ANGLE } \\
\left(\theta^{\circ}\right)\end{array}$ \\
\hline 201 & 0 & 25 & 100 & 300 & 0.8 & $S$ \\
\hline 204 & 0 & 25 & 100 & 305 & 0.8 & $S$ \\
\hline 196 & 0 & 575 & 70 & 210 & 0.6 & $S$ \\
\hline 208 & 0 & 900 & 70 & 205 & 1.2 & $s$ \\
\hline 212 & 0 & 1030 & 0 & 5 & 0.2 & PM \\
\hline 202 & 50 & 25 & 185 & 400 & 1.6 & 5 \\
\hline 203 & 50 & 25 & 230 & 540 & 1.2 & 28 \\
\hline $209^{b}$ & 50 & 25 & 215 & 500 & 1.2 & 28 \\
\hline 193 & 50 & 600 & 165 & 345 & 0.8 & $S$ \\
\hline 194 & 50 & 600 & 150 & 300 & 0.8 & $s$ \\
\hline 197 & 50 & 700 & 150 & 300 & 0.9 & 28 \\
\hline 199 & 50 & 925 & 120 & 205 & 0.3 & $40, S$ \\
\hline 210 & 50 & 940 & 100 & 145 & 1.2 & 28 \\
\hline 198 & 50 & 965 & 70 & 65 & 1.3 & 42 \\
\hline 205 & 50 & 1000 & 80 & 95 & 1.4 & UF \\
\hline $220^{c}$ & 0 & 25 & 70 & 210 & 1.4 & $s$ \\
\hline $222^{d}$ & 0 & 25 & 75 & 220 & 1.8 & $S$ \\
\hline 224 & 50 & 25 & 235 & 550 & 1.3 & $32, \mathrm{~s}$ \\
\hline 246 & 100 & 700 & 255 & 465 & 1.3 & 30 \\
\hline 277 & 100 & 720 & 240 & 425 & 1.2 & 28 \\
\hline 253 & 100 & 910 & 175 & 230 & 1.2 & 30 \\
\hline 279 & 100 & 950 & 140 & 115 & 1.5 & 5 \\
\hline · 248 & 100 & 1000 & 160 & 180 & 2.0 & $s$ \\
\hline
\end{tabular}

a. $S=$ shattered ( 2 or more fractures or faults), $P M=$ partial melting; UF : uniform flow and multiple fractures.

b. Specimen heated to $750^{\circ} \mathrm{C}$ at $10^{\circ} \mathrm{C} / \mathrm{min}$, cooled, and deformed at $25^{\circ} \mathrm{C}$ and $50 \mathrm{MPa}$.

c. Unconfined specimen heated to $905^{\circ} \mathrm{C}$ at $1.5^{\circ} \mathrm{C} / \mathrm{min}$, cooled, and deformed at $25^{\circ} \mathrm{C}$.

d. Unconfined specimen heated to $1000^{\circ} \mathrm{C}$ at $1.5^{\circ} \mathrm{C} / \mathrm{min}$, cooled, and deformed at $25^{\circ} \mathrm{C}$. 


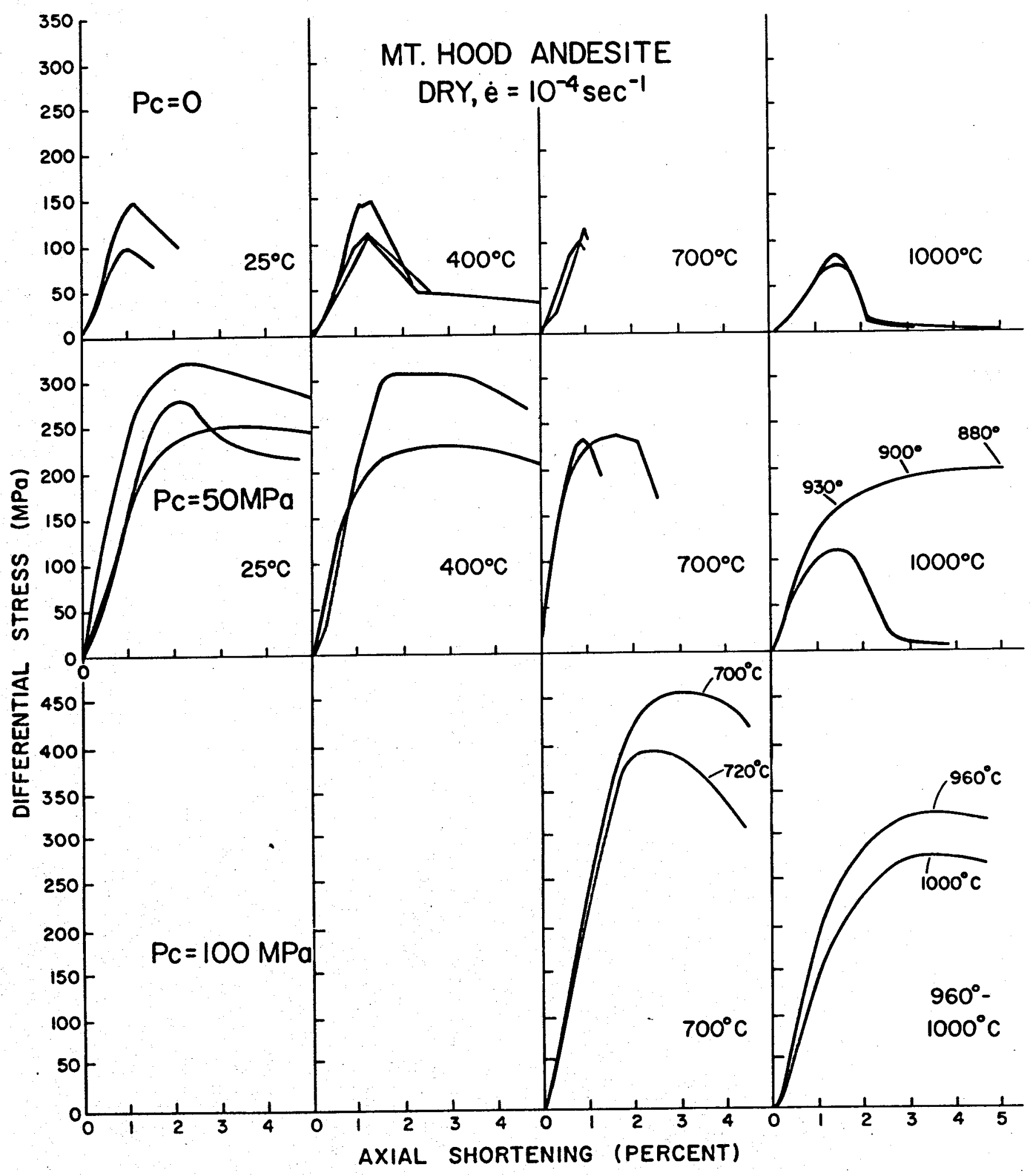

Figure 3. Stress-shortening curves for room-dry Mt. Hood Andesite deformed at the confining pressures $\left(P_{C}\right)$ and temperatures shown. 


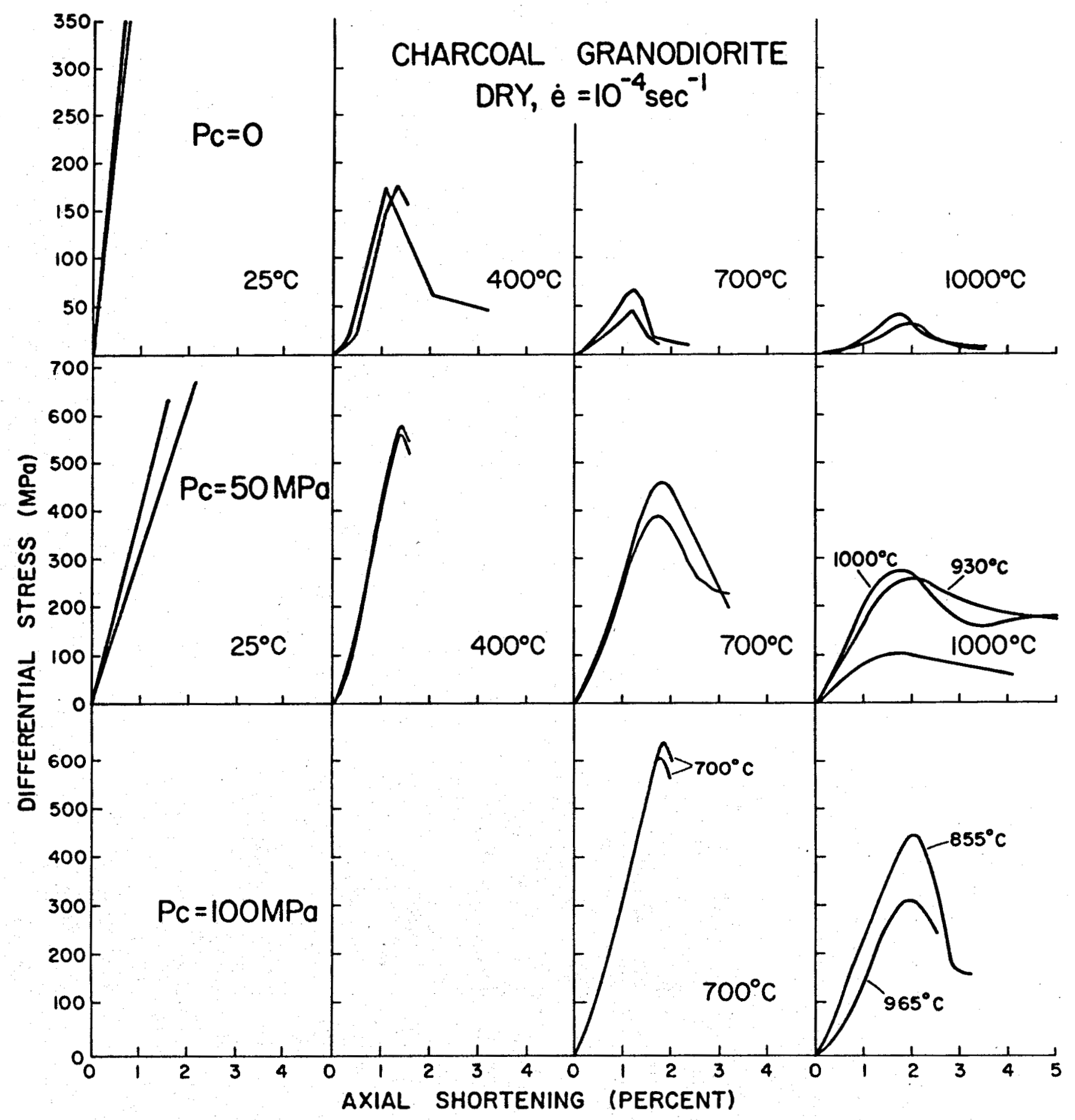

Figure 4. Stress-shortening curves for room-dry Charcoal Granodiorite deformed at the confining pressures $\left(P_{C}\right)$ and temperatures shown. 


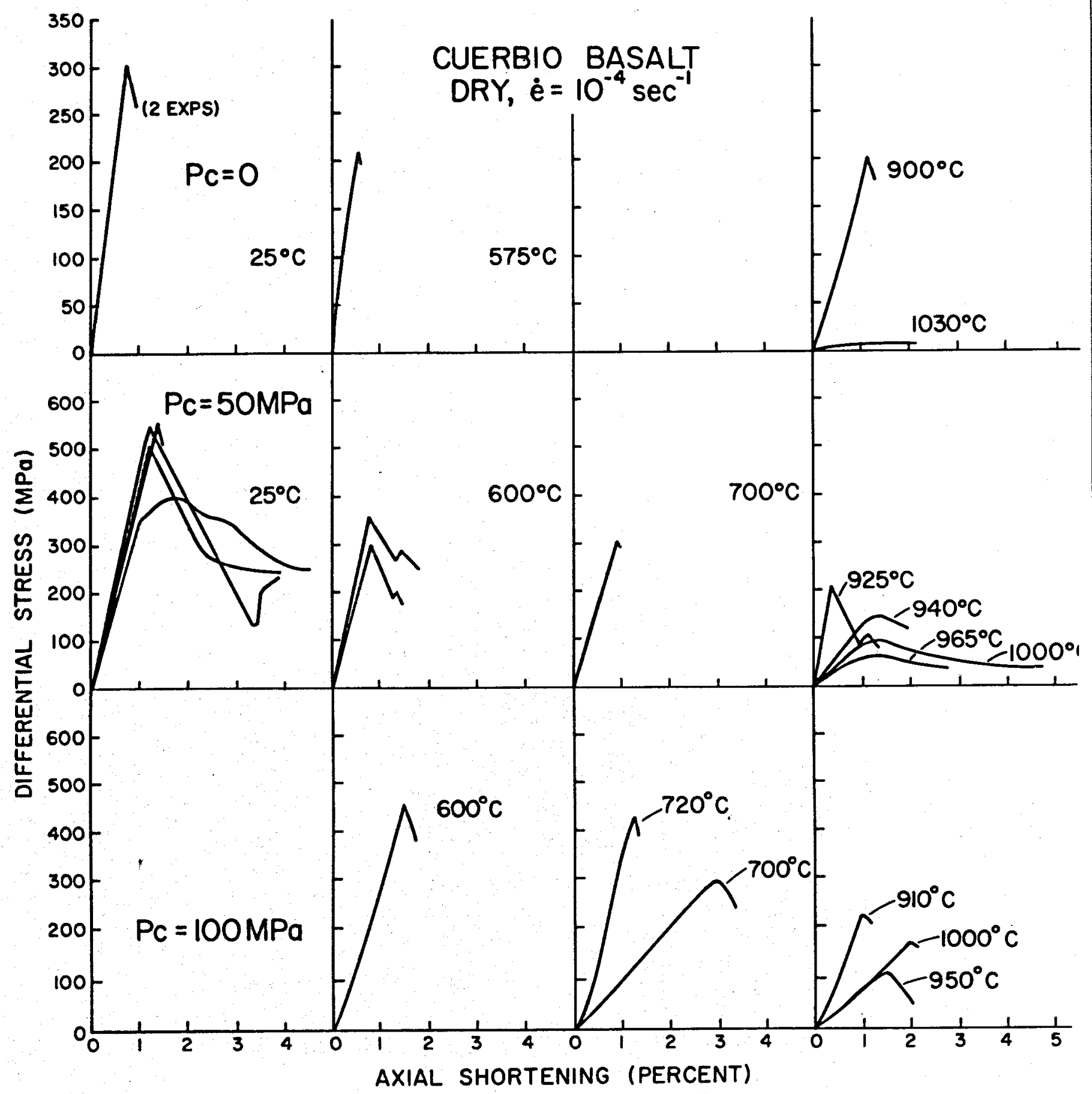

Figure 5. Stress-shortening curves for room-dry Cuerbio Basalt deformed at the confining pressures $\left(P_{C}\right)$ and temperatures shown. 


\section{MT. HOOD ANDESITE}

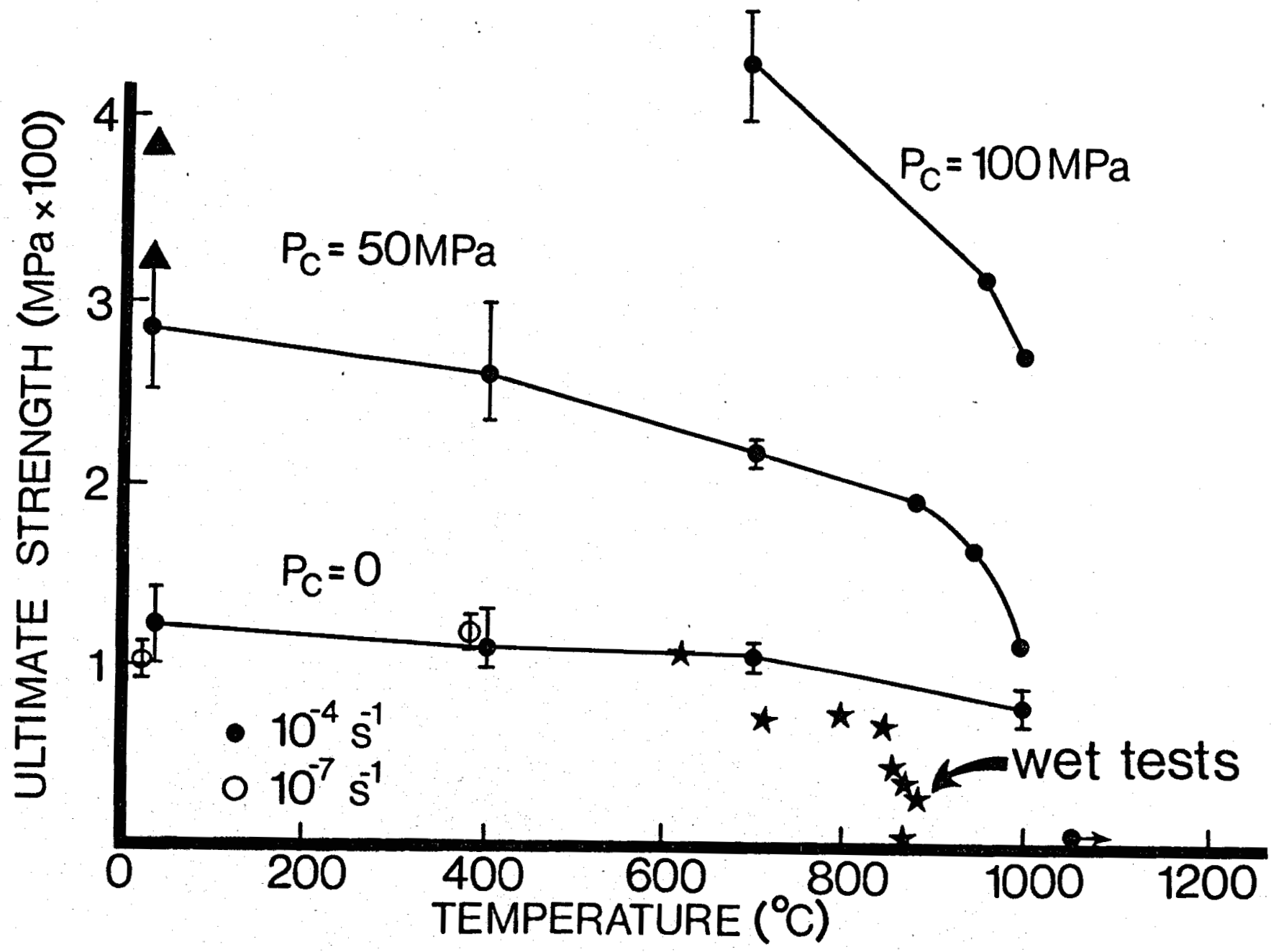

Figure 6. Ultimate strength versus temperature plot for Mt. Hood Andesite. Solid and open circles are data from room-dry specimens at confining pressures of 0,50 , and $100 \mathrm{MPa}$. Solid stars are data for water-saturated specimens with zero effective pressure. Triangles represent dry specimens heated to $930^{\circ}$ $1000^{\circ} \mathrm{C}$, cooled and deformed at $25^{\circ} \mathrm{C}, 50 \mathrm{MPa}$. The unconfined, dry strength at $25^{\circ} \mathrm{C}$ is virtually the same whether or not a specimen has been preheated and cooled. 


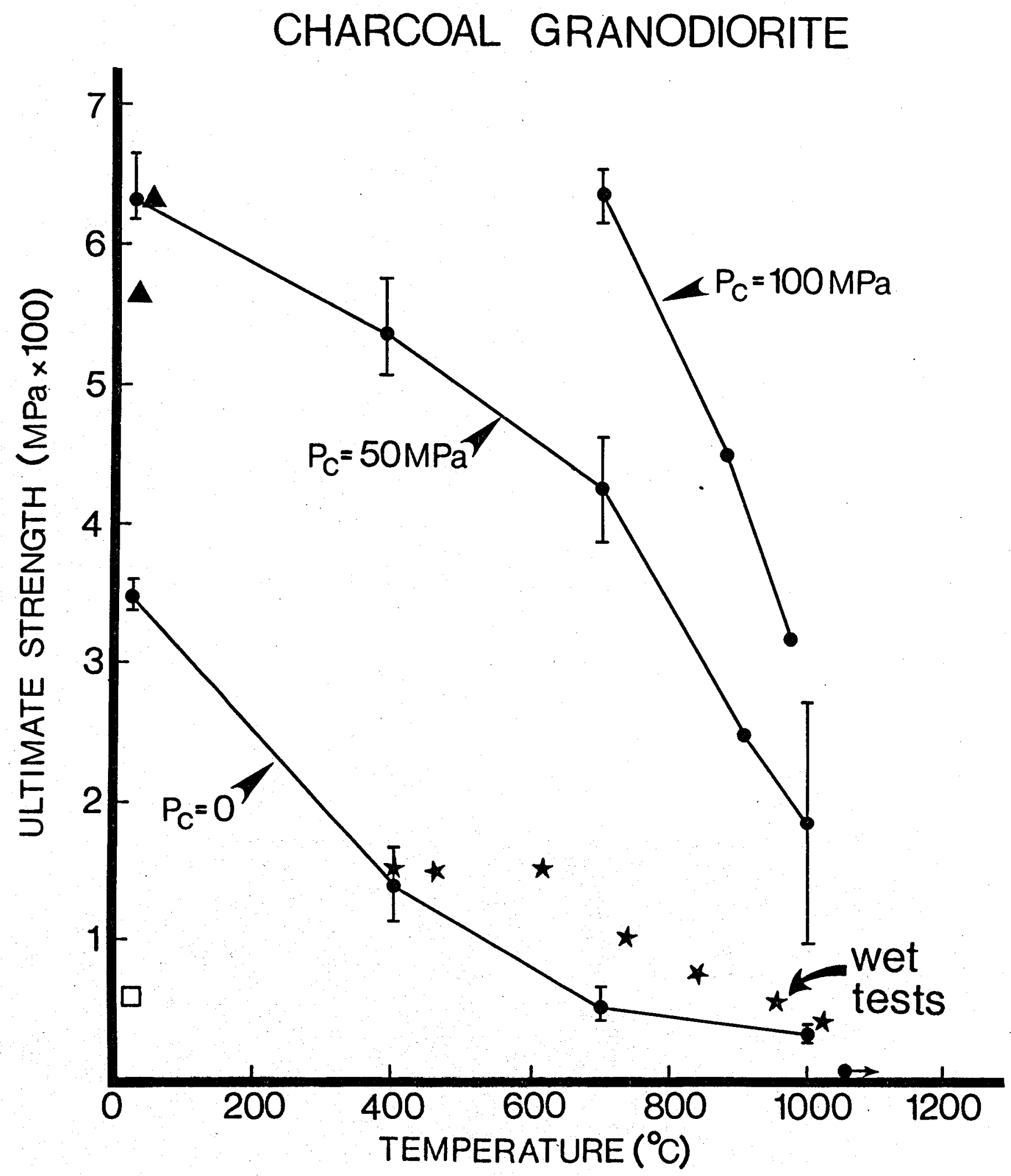

Figure 7. Ul timate strength versus temperature plot for Charcoal Granodiorite Solid circles are data points at confining pressures of 0,50 , and $100 \mathrm{MPa}$, room-dry specimens. Solid stars are data for water-saturated rocks with zero effective pressure. Triangles represent specimens heated $\mathrm{dry}$ to $1000^{\circ} \mathrm{C}$, then cooled and deformed at $25^{\circ} \mathrm{C}, 50 \mathrm{MPa}$. Open square represents three dry, unconfined specimens heated to $900^{\circ}-1000^{\circ} \mathrm{C}$, then cooled and deformed at $25^{\circ} \mathrm{C}$. 


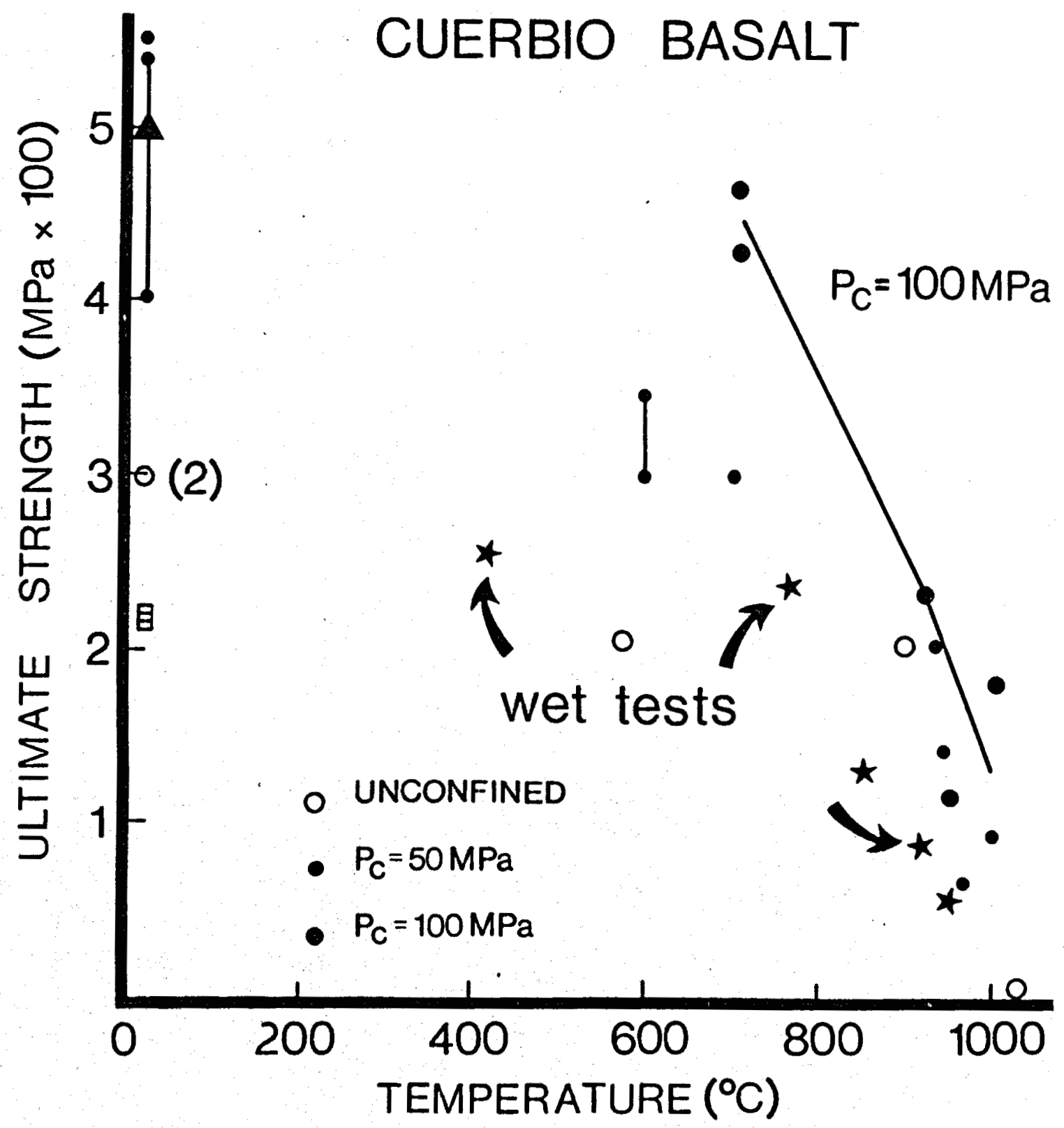

Figure 8. U1 timate strength versus temperature plot for Cuerbio Basalt. Solid and open circles are data from room-dry specimens at confining pressures of 0,50 , and $100 \mathrm{MPa}$. Solid stars are data for water-saturated specimens at zero effective pressure. Triangle represents a dry specimen heated to $750^{\circ} \mathrm{C}$, then cooled and deformed at $25^{\circ} \mathrm{C}, 50 \mathrm{MPa}$. Open squares represent unconfined, dry specimens heated to $905^{\circ}-1000^{\circ} \mathrm{C}$, then cooled and deformed at $25^{\circ} \mathrm{C}$. 
and $3 \mathrm{MPa} / 25^{\circ} \mathrm{C}$ unconfined. Our data are bracketed by those of Lindholm et al. (1974) on Dresser Basalt (a little stronger) and Murrell and Chakravarty (1973) on dolertie (a little weaker).

(3) The effect of confining pressure is to strengthen the rocks at each temperature (Figures 6,7 , and 8 ). Howeyer, this effect diminishes as $T_{m}$ is approached, i.e., the lines connecting the 0,50 , and $100-\mathrm{MPa}$ confining pressure data tend to converge at temperatures of $1000^{\circ} \mathrm{C}$ and higher. Plots of ultimate strength versus mean stress are reasonably linear at all temperatures as discussed below.

(4) The strengths of the rocks vanish when even partial melting occurs. This takes $\mathrm{place}$ at a nominal temperature of about $1030^{\circ} \mathrm{C}$ at the hotter end of a basalt specimen. A few unconfined tests were done on andesite and granodiorite at about $1250^{\circ} \mathrm{C}$ (not listed). Nearly complete melting locally was achieved as would be expected as the liquidus temperatures of al1 phases range from $1100^{\circ}$ to $1240^{\circ} \mathrm{C}$.

We have determined the equivalent viscosity, $n=\left(\sigma_{1}-\sigma_{3}\right) / 3 \dot{\varepsilon}$, of the unconfined, partially melted rocks under a constant axial load due merely to the weight of the loading piston, about $0.1 \mathrm{MPa}$ on the $2-\mathrm{cm}$ specimens, by measuring the ensuing axial strain as a function of time (creep test). For andesite and granodiorite viscosities are of the order of $10^{7} \mathrm{~N} \cdot \mathrm{s} / \mathrm{m}^{2}$, and for the lesser melted basalt about $10^{9}$. These values agree well with those of Murase and MCBirney (1973), determined by a quite different technique, beam-bending.

(5) All three rocks are brittle throughout the temperature range explored until melting occurs (Tables $1-3$ ). Shortenings at failure are less than 3 percent. Between $25^{\circ}$ and $700^{\circ} \mathrm{C}$ the shortening at failure 
tends to be either constant or even to decrease.

(6) Most of the stress-shortening curves exhibit pronounced worksoftening after the onset of macroscopic failure. This reflects displacement along faults that have not lost total resistance to differential stress.

(7) A few tests on the andesite and granodiorite were made at $10^{-7} / \mathrm{s}$, $25^{\circ}$ and $400^{\circ} \mathrm{C}$, unconfined and $50 \mathrm{MPa}$ (Tables 1 and 2). Except for a 30 percent weakening of the andesite at room temperature and $50 \mathrm{MPa}$, the 1000 -fold decrease in strain rate from $10^{-4} / \mathrm{s}$ has negligible effects on strength or ductility.

(8) Two types of tests were made to investigate the cause(s) of the temperature-weakening. All three rocks were first heated at $50 \mathrm{MPa}-\mathrm{con}-$ fining pressure to temperatures between $750^{\circ}$ and $1000^{\circ} \mathrm{C}$, cooled to $25^{\circ} \mathrm{C}$, and then deformed at confining pressure. The rocks are as strong after thermal cycling as before (Figures 6,7 , and 8 ), so that the thermal cracking caused by the relatively rapid heating and cooling $\left(1.5^{\circ} \mathrm{C} / \mathrm{min}\right.$ or $\left.10^{\circ} \mathrm{C} / \mathrm{min}\right)$ is not the cause of strength reductions. Indeed, specimens of the andesite are an average of 25 percent stronger after therma 1 treatment (Figure 6), for reasons not yet understood. On the other hand, similar thermal treatment greatly reduces the strength of the unconfined rocks presumably because the effect of thermal cracking has not been suppressed by confining pressure.

In one inadvertant experiment, a specimen of andesite was heated to $980^{\circ} \mathrm{C}$ under $50 \mathrm{MPa}$-confining pressure and then deformed (Figure 3). During the shortening the internal furnace failed and the temperature fell to $880^{\circ} \mathrm{C}$ when the test was terminated at 6 percent strain, short of macroscopic 
failure. Instead of failing at 1 or 2 percent strain, as expected from previous experiments at constant temperature, the specimen work-hardened from $165 \mathrm{MPa}$ at $930^{\circ} \mathrm{C}$ to $190 \mathrm{MPa}$ at $900^{\circ} \mathrm{C}$ to $195 \mathrm{MPa}$ at $880^{\circ} \mathrm{C}$. The strengths at these temperatures fall on the curve established by constanttemperature experiments. These data need to be reproduced, but these preliminary results certainly suggest that temperature affects fracture strength, and does not merely degrade the strength of the rock through thermal cracking, at least under confining pressure.

Water-Saturated Experiments. To date 18 successful experiments have been conducted on water-saturated specimens of the three rocks at zero effective confining pressure, temperatures from $400^{\circ}$ to $1015^{\circ} \mathrm{C}$, and at a constant strain rate of $10^{-4} \mathrm{~s}^{-1}$ (Table 4). The stress-strain curves from these tests all show nearly linear rise to a peak differential stress (ultimate strength) at strains of $\leq 1.0$ percent and then a work-softening phase to axial strains up to 4.5 percent (Figure 9). Displacements during work softening probably are along multiple macroscopic fractures (shattered specimens) or along discrete faults (Table 4). A11 tests were stopped prior to complete loss of cohesion.

Ul timate (fracture) strengths of the wet granodiorite show no waterweakening (Figure 7). In fact, between $400^{\circ}$ and $1015^{\circ} \mathrm{C}$ the specimens are somewhat stronger than their dry counterparts. This suggests that the pore fluid probably is not in pressure equilibrium throughout the specimen so the effective pressure $\left(P_{c}-P_{p}\right)$ is $>0$ (but much less than 50 $M P a)$. In contrast, the Mt. Hood Andesite shows pronounced weakening between 850 and $880^{\circ} \mathrm{C}$, at which point its fracture strength is between 5 and $25 \mathrm{MPa}$ (Figure 6). In comparison its dry strength is $75 \mathrm{MPa}$ at 
Table 4 Experimental Data for Water-Saturated Charcoal Granodiorite, Cuerbio Basalt and Mt. Hood Andesite Shortened at $10^{-4} \mathrm{~s}^{-1}$.

\begin{tabular}{|c|c|c|c|c|c|c|c|c|}
\hline $\begin{array}{c}\text { Rock Type } \\
\text { and } \\
\text { Specimen No. }\end{array}$ & $\begin{array}{l}\text { Confining } \\
\text { Pressure } \\
\text { (MPa) }\end{array}$ & $\begin{array}{c}\text { Pore } \\
\text { Pressure } \\
\text { (MPa) }\end{array}$ & $\begin{array}{l}\text { Effective } \\
\text { Pressure } \\
\text { (MPa) }\end{array}$ & $\begin{array}{l}\text { Temp. } \\
\left({ }^{\circ} \mathrm{C}\right)\end{array}$ & $\begin{array}{l}\text { Mean } \\
\text { Stress } \\
(\mathrm{MPa})\end{array}$ & $\begin{array}{l}\text { vitimate } \\
\text { Strength } \\
\text { (MPa) }\end{array}$ & $\begin{array}{l}\text { Shortening } \\
\text { at Failure } \\
(\%)\end{array}$ & \\
\hline \multicolumn{9}{|c|}{ CHARCOAL GRANODIORITE } \\
\hline 280 & 100 & 100 & 0 & 400 & 50 & 150 & 0.7: & Shattered, work-softened to $50 \mathrm{MPa}$ at $1.9 \%$ shortening. \\
\hline 286 & 50 & 45 & 5 & 460 & 50 & 150 & - & $\theta=23^{\circ}$, THeated at differential stress of $150 \mathrm{MPa}$ until specimen failed. \\
\hline 287 & 50 & 45 & 5 & 610 & 50 & 150 & - & Shattered ( \\
\hline 289 & 50 & 50 & 0 & 740 & 35 & 100 & 1.0 & Shattered, work-softened along multiple fractures to $45 \mathrm{MPa}$ at $2.7 \%$ shortening. \\
\hline 291 & 50 & 50 & $\mathbf{0}$ & 835 & 25 & 75 & 1.0 & $\theta=34^{\circ}$, work-softened along fault to $15 \mathrm{MPa}$ at $2.5 \%$ shortening. \\
\hline 294 & 50 & 50 & 0 & 945 & 20 & 55 & 0.9 & $\theta=34^{\circ}$, work-softened along fault to $15 \mathrm{MPa}$ at $2.1 \%$ shortening. \\
\hline 308 & 50 & 50 & o & 1015 & 15 & 40 & 0.6 & Shattered, work-softened along fault to $25 \mathrm{MPa}$ at $3.2 \%$ shortening. \\
\hline \multicolumn{9}{|c|}{ CUERBIO BASALT } \\
\hline 296 & 50 & 50 & $\mathbf{0}$ & 415 & 85 & 255 & 0.6 & Shattered, work-softened along multiple fractures to $115 \mathrm{MPa}$ at $1.7 \%$ shortening. \\
\hline 304 & 50 & 50 & $\mathbf{0}$ & 765 & 80 & 235 & 0.8 & Shattered, work-softened with stick-slip to $135 \mathrm{MPa}$ at $2.5 \%$ shortening. \\
\hline 307 & 50 & 50 & 0 & 916 & 30 & 90 & 0.9 & Shattered, work-softened along multiple fractures to $60 \mathrm{MPa}$ at $3.4 \%$ shortening. \\
\hline 309 & 50 & 50 & 0 & 850 & 45 & 135 & 0.3 & Shattered. \\
\hline 310 & 50 & 50 & $\mathbf{0}$ & 945 & 20 & 60 & 0.1 & Shattered, work softened along multiple fractures to $45 \mathrm{MPa}$ at $2.7 \%$ shortening. \\
\hline \multicolumn{9}{|c|}{ MT. HOOD ANDESITE } \\
\hline 306 & 50 & 50 & 0 & 615 & 35 & 105 & 0.6 & Shattered, work-softened along multiple fractures to $25 \mathrm{MPa}$ at $1.8 \%$ shortening. \\
\hline 290 & 50 & 50 & $\mathbf{0}$ & 720 & 25 & 70 & 0.6 & Shattered, work-softened along multiple fractures to $25 \mathrm{MPa}$ at $2.0 \%$ shortening. \\
\hline 300 & 50 & 50 & 0 & 800 & 25 & 70 & 0.6 & Shattered, work-softened along multiple fractures to $20 \mathrm{MPa}$ at $3.5 \%$ shortening. \\
\hline 301 & 50 & 50 & 0 & 845 & 20 & 65 & 0.8 & Shattered, work-softened along multiple fractures to $15 \mathrm{MPa}$ at $4.0 \%$ shortening. \\
\hline 302 & 50 & 50 & 0 & 855 & 15 & 40 & 0.8 & Shattered, work-softened along multiple fractures to $15 \mathrm{MPa}$ at $4.3 \%$ shortening. \\
\hline 303 & 50 & 50 & 0 & 870 & 10 & 35 & 0.8 & Shattered, work-softened along multiple fractures to $20 \mathrm{MPa}$ at $3.1 \%$ shortening. \\
\hline 297 & 50 & 50 & 0 & 870 & 0 & 5 & 1.0 & Ductile, no fracturing or faulting, total shortening $2.8 \%$ before test stopped. \\
\hline 305 & 50 & 50 & 0 & 880 & 10 & 25 & 0.7 & Shattered, work-softened along multiple fractures to $10 \mathrm{MPa}$ at $2.3 \mathrm{~T}$ shortening. \\
\hline
\end{tabular}




$$
\mathrm{H}_{2} \mathrm{O} \text {-SATURATED TESTS, } \mathrm{Pe}=\mathrm{O}
$$

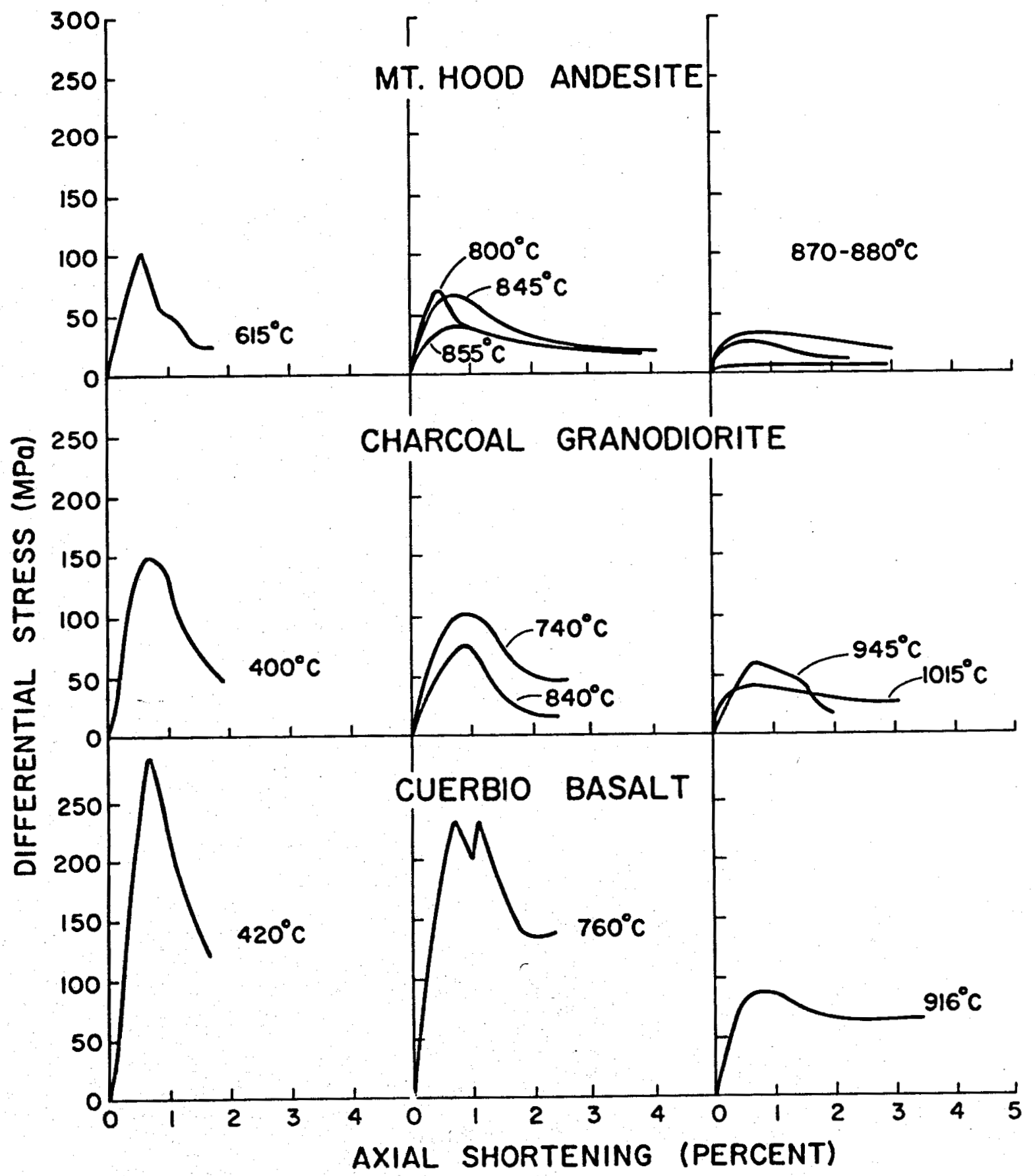

Figure 9. Stress-shortening curves for water-saturated specimens of the three crystalline rocks deformed at zero effective confining pressure ( confining and pore pressures equal to $50 \mathrm{MPa}$ ) and at temperatures shown. 
$1000^{\circ} \mathrm{C}$. The andesite has a much higher porosity than the granodiorite so that pervasive water-pressure equilibration is more likely. Certainly the lower strength of wet andesite suggests $P_{e}$ is small if not zero, and there does appear to be a water-weakening effect. Ultimate strengths are available for only five wet specimens of the basalt (Figure 8). Although sparse, the data suggest no weakening or apparent strengthing at temperatures to $763^{\circ} \mathrm{C}$. There is, perhaps some weakening at $>850^{\circ} \mathrm{C}$. Clearly more data are needed for this rock, and conclusions made below are based primarily on the andesite and granodiorite.

To date, only systematic macroscopic observations of the deformed specimens have been made. Most of the specimens exhibit two or more shear fractures (noted as "shattered," Table 1) with their traces clearly imprinted on the copper jackets. Only three of the granodiorite specimens deformed along single discrete shear fractures. Clearly, the rocks are remaining brittle in their mechanical response to the test conditions. Granodiorite specimen $308\left(1015^{\circ} \mathrm{C}\right)$ and andesite specimen $297\left(870^{\circ} \mathrm{C}\right)$ were welded to their end pieces so that fragments of the rock adhered to the end piece upon disassembly. Some local melting was suspected but none was observed with a binocular microscope or in thin sections cut from these specimens.

Obsidian

Short-Term Behavior. The strength and ductility of dry Newberry Rhyolite Obsidian has been determined at 0 and $50 \mathrm{MPa}$ pressure, at temperatures to $800^{\circ} \mathrm{C}$, and at a strain rate of $2 \times 10^{-4} / \mathrm{s}$ (Table 5 , Figures 10 and 11). U1timate strength decreases dramatically from $665 \mathrm{MPa}$ at $600^{\circ} \mathrm{C}$ to $15 \mathrm{MPa}$ at $800^{\circ} \mathrm{C}$ (Figure 12); the brittle-ductile transition 
Table 5. Experimental Data for Dry, Newberry Rhyolite Deformed at $10^{-4} \mathrm{Sec}^{-1 *}$.

\begin{tabular}{|c|c|c|c|c|c|c|}
\hline $\begin{array}{c}\text { Specimen } \\
\text { No. }\end{array}$ & $\begin{array}{l}\text { Confining } \\
\text { Pressure } \\
\text { (MPa) }\end{array}$ & $\begin{array}{l}\text { Temp. } \\
\left({ }^{\circ} \mathrm{C}\right)\end{array}$ & $\begin{array}{l}\text { Mean } \\
\text { Stress } \\
\text { (MPa) }\end{array}$ & $\begin{array}{l}\text { Ultimate } \\
\text { Strength } \\
\text { (MPa) }\end{array}$ & $\begin{array}{l}\text { Shortening } \\
\text { at Faflure }(F) \\
\text { at Yielding }(Y) \\
(\%)\end{array}$ & Comments. \\
\hline 144 & 0 & 600 & 222 & 666 & $3.5(F)$ & Shattered \\
\hline 145 & 0 & 700 & 47 & 141 & $1.0-2.0(Y)$ & Shortened to $6.2 \%$ then allowed to relax \\
\hline 135 & 0 & 700 & 76 & 228 & $2.0-4.0(Y)$ & Shortened to $7.2 \%$ then allowed to relax \\
\hline 149 & 0 & 750 & 9 & 27 & $0.7(Y)$ & Shortened to $3.8 \%$ then allowed to relax \\
\hline 151 & 0 & 750 & 10 & 30 & $0.7(Y)$ & Shortened to $4.6 \%$ then allowed to relax \\
\hline $153^{* * c}$ & 0 & 770 & 17 & 50 & $0.5-1.0(Y)$ & Shortened to $4.2 \%$ then allowed to relax \\
\hline $153 a$ & 0 & 800 & 5 & 14 & $0.6(Y)$ & Shortened to $3.1 \%$ then allowed to relax \\
\hline $153 b$ & 0 & 800 & 5 & 15 & $0.4(Y)$ & Shortened to $2.9 \%$ then allowed to relax \\
\hline 134 & 50 & 400 & 323 & $>820$ & $4.1 \cdot(F)$ & $\begin{array}{l}\text { Shattered, possible fracture in lucalox spacer } \\
\text { at } \Delta \sigma \text { of } 670 \mathrm{MPa} \text {; specimen fallure related } \\
\text { to failure of lucalux }\end{array}$ \\
\hline 168 & 50 & 700 & 155 & 315 & $0.8(Y)$ & Shortened to $9.7 \%$ then allowed to relax \\
\hline 170 & 50 & 700 & 165 & 344 & $0.8(Y)$ & Shortened to $9.0 \%$ then allowed to relax \\
\hline $172 c * \star$ & 50 & 735 & 100 & 148 & $0.5(Y)$ & Shortened to $5.3 \%$ then allowed to relax \\
\hline 169 & 50 & 750 & 80 & 91 & $0.5(Y)$ & Shortened to $8.3 \%$ then allowed to relax \\
\hline $172 b$ & 50 & 765 & 61 & 32 & $0.1(Y)$ & Shortened to $2.6 \%$ then allowed to relax \\
\hline $172 a$ & 50 & 800 & 52 & 5 & $0.1(Y)$ & Shortened to $2.0 \%$, These specimens are too \\
\hline 171 & 50 & 800 & 52 & 7 & $0.1(Y)$ & Shortened to $6.8 \%$. weak for relaxation tests \\
\hline
\end{tabular}

* Strain rates actually vary from $2.2 \times 10^{-4} \mathrm{sec}^{-1}$ to $4.4 \times 10^{-4} \mathrm{sec}^{-1}$, however effects of these small differences on strength and ductility are negl igible.

* Specimens 153 and 172 were deformed three times in the order $a, b$, and then $c$. For each cycle of loading the same specimen was shortened, relaxed, and then reloaded. 


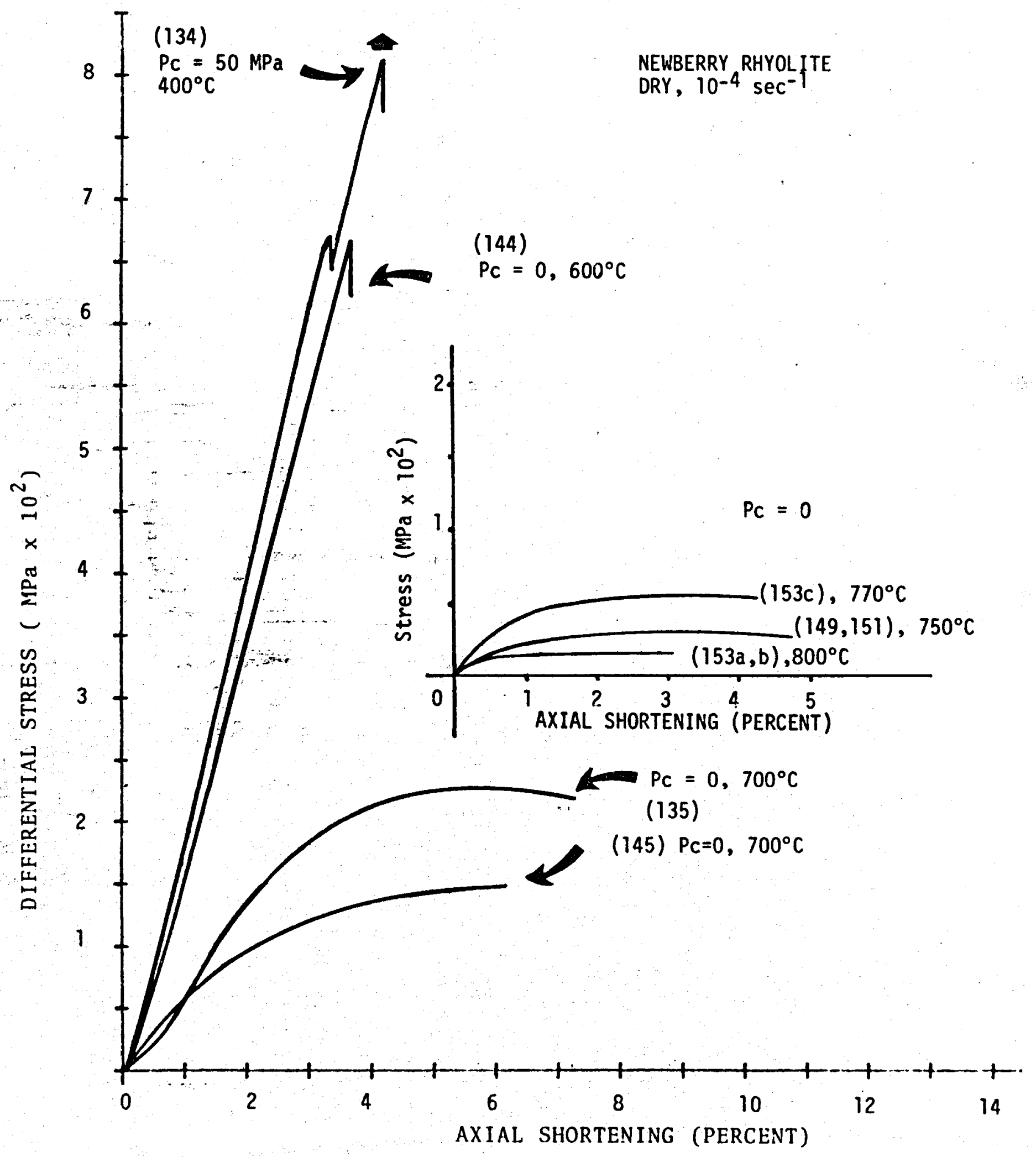

Figure 10. Stress-shortening curves for room-dry Newberry Rhyolite Obsidian at temperatures to $800^{\circ} \mathrm{C}$. Experimental conditions and specimen numbers (in parentheses) are listed after each curve. Note scale change for insert plot. 


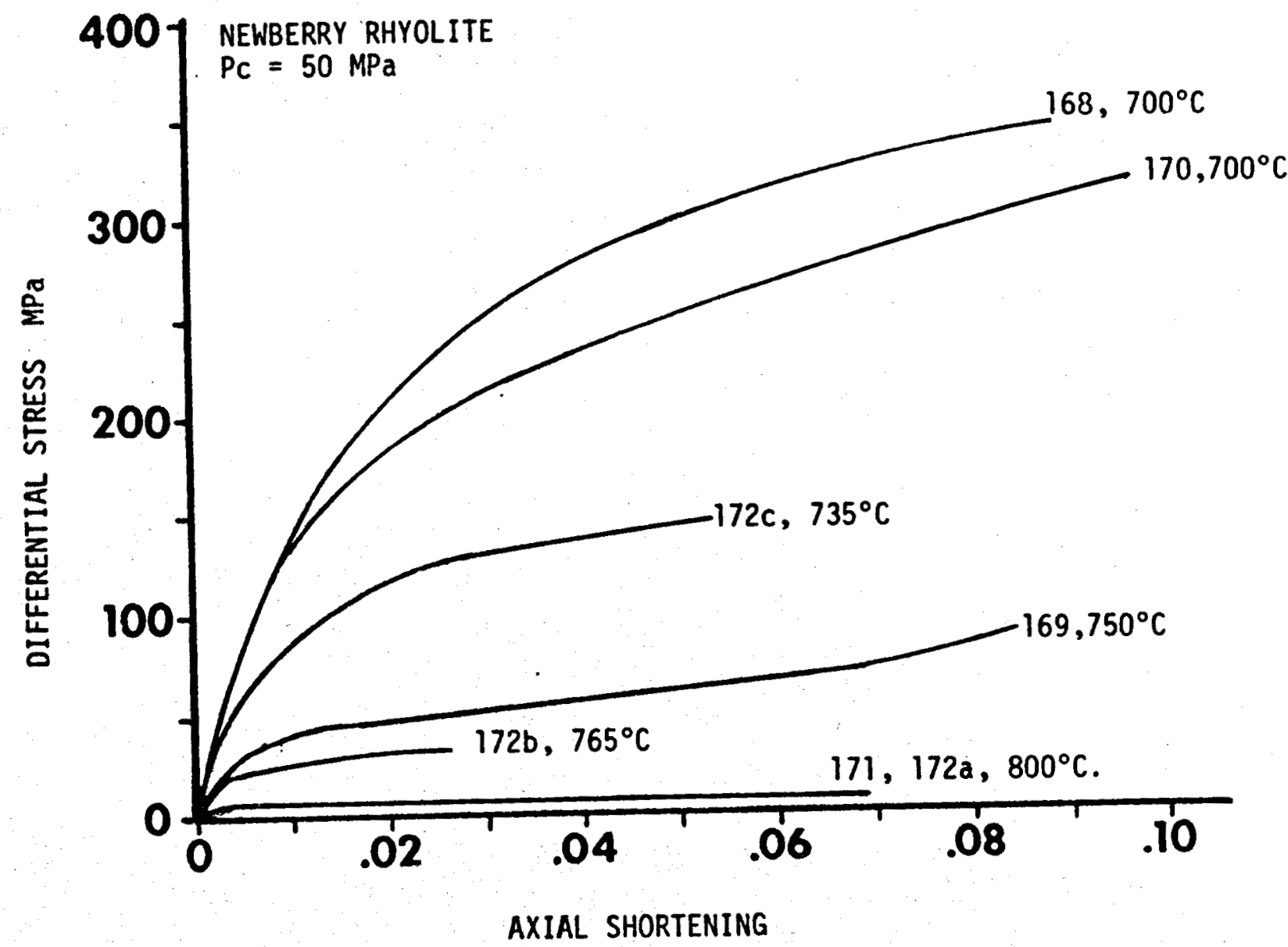

Figure 11. Stress-shortening curves for Newberry Rhyolite Obsidian at $50 \mathrm{MPa}$-confinjing pressure, temperatures to $800^{\circ} \mathrm{C}$, and strain rate of about $3 \times 10^{-4}$ sec $^{-1}$. Temperature and specimen numbers are listed after each curve. 
34

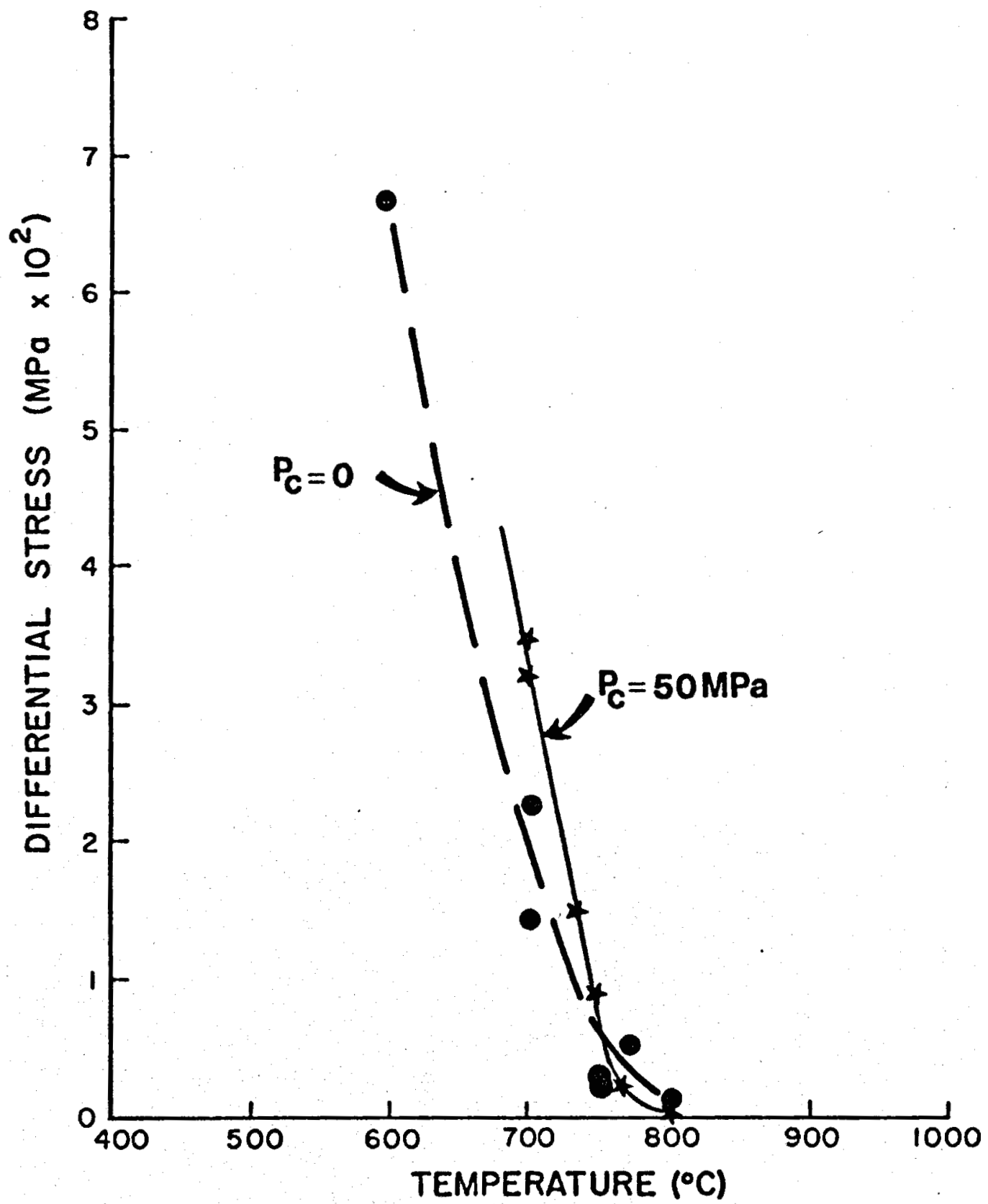

Figure 12. Ultimate strength versus temperature plot for room dry Newberry Rhyolite Obsidian. 
occurs between $600^{\circ}$ and $700^{\circ} \mathrm{C}$; and work-hardening ceases and steady-state flow obtains between $700^{\circ}$ and $750^{\circ} \mathrm{C}$.

Data at $50 \mathrm{MPa}$ are not appreciably different (Table 5). Between $700^{\circ}$ and $750^{\circ} \mathrm{C}$ the obsidian is somewhat stronger at $50 \mathrm{MPa}$ than unconfined, but the opposite is true between $750^{\circ}$ and $800^{\circ} \mathrm{C}$. In short, the increment of $50 \mathrm{MPa}$ in confining pressure has insignificant effects on short-time strength and ductility.

Time-Dependent Flow. Stress-relaxation tests (Lee and Hart, 1971; Rutter et a1., 1978) were made on 7 unconfined and 5 confined specimens $\left(50 \mathrm{MPa}\right.$ ) at temperatures between $700^{\circ}$ and $800^{\circ} \mathrm{C}$ (Table 5). In these experiments, the loading pump is switched off at the end of the usual constant strain-rate path. The load supported by the specimen then decays with time as the stored elastic strains in the machine and specimen are converted into permanent strain within the specimens.

Assuming that the volume of hydraulic fluid in the loading ram remains constant during the relaxation, and that any anelastic relaxations of the machine are negligible, one can relate the permanent displacement, $\Delta d_{p}$, induced in the specimen to the force drop, $\Delta F$, through the machine stiffness, $k_{m}$, and the specimen stiffness, $k_{s}$, as

$$
\Delta d_{p}=-\left(\frac{1}{k_{m}}+\frac{1}{k_{s}}\right) \Delta F
$$

For specimens that are essentially inelastic (viscous) in behavior, the equation reduces to:

$$
\Delta d_{p}=-\frac{1}{k_{m}} \Delta F \text {. }
$$


Taking time derivatives, one can write

$$
a_{p}=-\frac{1}{k_{m}} \dot{F} .
$$

Thus, by plotting curves of $F$ against $t$ and taking the gradient at specific points on the ensuing curve, one finds a data set relating $F$ and $\dot{d}_{p}$, provided that the stiffnesses of the relevant parts of the machine are known. For these particular tests, the total machine stiffness, $1.23 \times$ $10^{8} \mathrm{~N} / \mathrm{m}$ is relevant. Strain rate, $\dot{\varepsilon}$, and differential stress $\left(\sigma_{1}-\sigma_{3}\right)$, are then calculated from the known length and cross-sectional area of the specimen at the start of the relaxation. Since the total induced strain during relaxation is very small $(<0.5 \%)$, it is not necessary to correct for changes in length or area. By this method we have obtained steadystate strength data at strain rates from $10^{-4}$ to $10^{-6} / \mathrm{s}$.

Equivalent Viscosities. From data on $\dot{\varepsilon}$ and $\left(\sigma_{1}-\sigma_{3}\right)$ during relaxation, equivalent viscosities are calculated for a given temperature. Unconfined viscosities at $10^{-4} \mathrm{~s}^{-1}$ decrease linearly from an average of $3.4 \times 10^{11}$ at $700^{\circ} \mathrm{C}$ to about $3 \times 10^{10} \mathrm{~N} \cdot \mathrm{s} / \mathrm{m}^{2}$ at $800^{\circ} \mathrm{C}$. These values agree closely with those determined for this same obsidian at the same temperatures, but with the beam-bending method by Murase and McBirney (1973, Figure 5). At $50 \mathrm{MPa}-c o n f i n i n g$ pressure, the equivalent viscosities decrease with increasing temperature along a slightly steeper slope, but the effect of the pressure increment is insignificant. The specimens deformed at 50 $\mathrm{MPa}$ and $800^{\circ} \mathrm{C}$ were too weak for meaningful stress-relaxation testing (Table 5).

Plot of $\log \dot{\varepsilon}$ against $\left(\sigma_{1}-\sigma_{3}\right)$ show a systematic variation with temperature at both confining pressures (Figure 13). The data fit a power law, $\dot{\varepsilon}\left(\sigma_{1}-\sigma_{3}\right)^{n}$, with linear least-squares values for $n$ ranging 

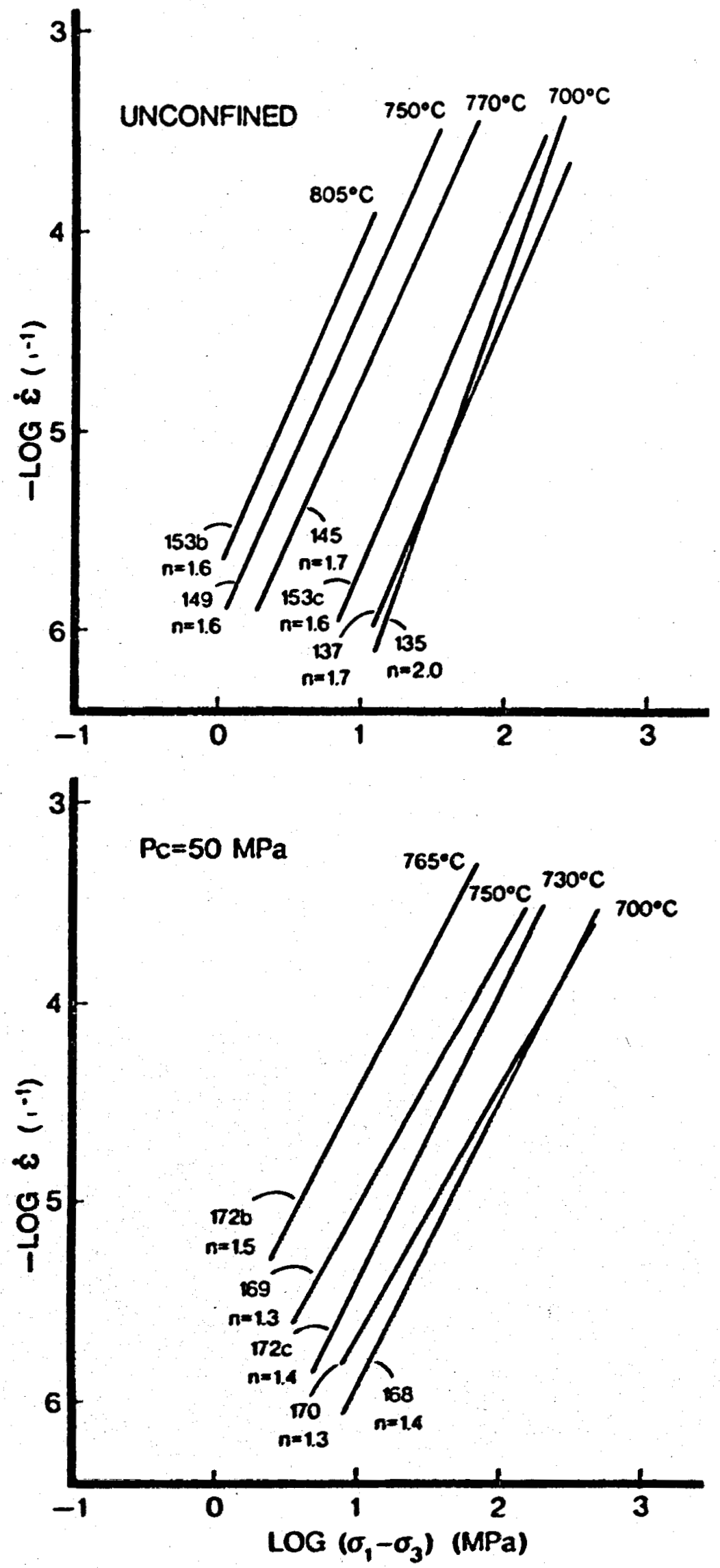

Figure 13. Log strain rate versus log steady-state flow stress plot for dry Newberry Rhyolite Obsidian at different temperatures and confining pressures. 
from about 2.0 at $700^{\circ} \mathrm{C}$ to about 1.6 at $800^{\circ} \mathrm{C}$ unconfined, and 1.3 to 1.5 , confined.

Finally, a flow law of the type

$$
\dot{\varepsilon}=A \exp (-Q / R T)\left(\sigma_{1}-\sigma_{3}\right)^{n}
$$

is fit to the data between $700^{\circ}$ and $800^{\circ} \mathrm{C}$. The constant $\mathrm{A}$ is $2 \times 10^{13}$ when $\sigma$ is in $\mathrm{MPa}$ and $\dot{\varepsilon}$ is $s^{-1}$; the activation energy for viscous flow is $Q=380 \mathrm{~kJ} / \mathrm{mol}$; $R$ is the gas constant; and $n=1.5$. (By using $n=1.5$, we ignore the very small effect of confining pressure.) Our value of $Q$ agrees remarkably well with the $400 \mathrm{~kJ} / \mathrm{mol}$ of Murase and McBirney (1973, Figure 6). We emphasize that this flow law has been determined only for temperatures between 700 and $800^{\circ} \mathrm{C}$ and $\dot{\varepsilon}$ from $10^{-4}$ to $10^{-6} \mathrm{~s}^{-1}$, and that the parameter, $n$, varies with temperature and strain rate. 


\section{PETROFABRIC OBSERVATIONS}

All specimens have been examined macroscopically, and thin- and polished-sections from over 50 dry specimens have been studied in detail to characterize the operative deformation mechanisms as functions of tem-

perature and pressure. ${ }^{*}$ Quantitative data consist of the angle $(\theta)$ between the load axis $\left(\sigma_{1}\right)$ and the macroscopic fault zone (Tables 1-4), microfracture abundance, and chemical composition of glasses developed upon partial melting. These are accompanied by qualitative assessments of microfracture orientation and distribution, thermal alteration ofminerals, gliding flow in mafic minerals, and development of glass in partially melted rocks.

Macrofractures

Studies of deformation mechanisms are made to gain insight into temperature effects on strength and ductility. All the rocks deform primarily by brittle fracture until partial melting (crystalline rocks) or glass softening (obsidian) occurs. Most specimens are shattered, i.e., they contain multiple faults (Tables 1-5). About 45 percent of the andesite, granodiorite and basalt specimens contain a discrete fault from which a reliable measure of $\theta$ can be obtained. This angle ranges between $23^{\circ}$ and $34^{\circ}$ for the andesite, $18^{\circ}$ and $36^{\circ}$ for the granodiorite, and $28^{\circ}$ and $42^{\circ}$ for the basalt. In general, $\theta$ tends to increase with increasing temperature. There is also a tendency for the fault zones to widen with increasing temperature and pressure.

*Thin section analyses of the $\mathrm{H}_{2} \mathrm{O}$-saturated specimens will not be made in time for inclusion in this report. They will be reported as part of the continuation of this effort funded by DOE. 
By comparing the data from the few tests on the andesite at $25^{\circ}$ and $400^{\circ} \mathrm{C}$ and 0 and $50 \mathrm{MPa}$ done at strain rates of both $10^{-4}$ and $10^{-7} / \mathrm{s}$ (Table 1 ), we note an unexpectedly large effect of time on the fracture angle, nearly $8^{\circ}$, not previously reported in the literature as far as we know (Figure 14).

\section{Microfractures}

Microscopically each fault zone (Figures 15 and 16) consists of pervasive, precursive, extension microfractures (oriented within $20^{\circ}$ of $\sigma_{1}$ ) and adjacent microscopic feather fractures (Friedman, 1975; Conrad and Friedman, 1976). Excellent examples are found of incipient faults along which en-echelon arrays of the precursive axial microfractures define the path of the eventual fault (Figures 15 and 16). Thermal fractures also occur; they are distinguishable by being relatively short, randomly oriented with respect to external coordinates, and located close to grain boundaries and/or larger fractures.

Detailed studies of microfracture abundances in the granodiorite and andesite have been made, and abundance is quantified as the average number of microfractures per $\mathrm{mm}$ intersected along linear traverses oriented perpendicular to the cylinder (load) axis. This abundance factor is obtained from 5 to 9 traverses with cumulative lengths of from 4.4 to 16.1 $\mathrm{mm}$, spaced 2 to $5 \mathrm{~mm}$ apart for each specimen. Traverses across gouge either ignore it or are equated to discrete microfractures by arbitrarily assigning 100 microfractures for each millimeter of finely comminuted gouge. Both load-induced and thermoelastic fractures are counted. (A measure of the later is afforded by study of specimens subjected only to 


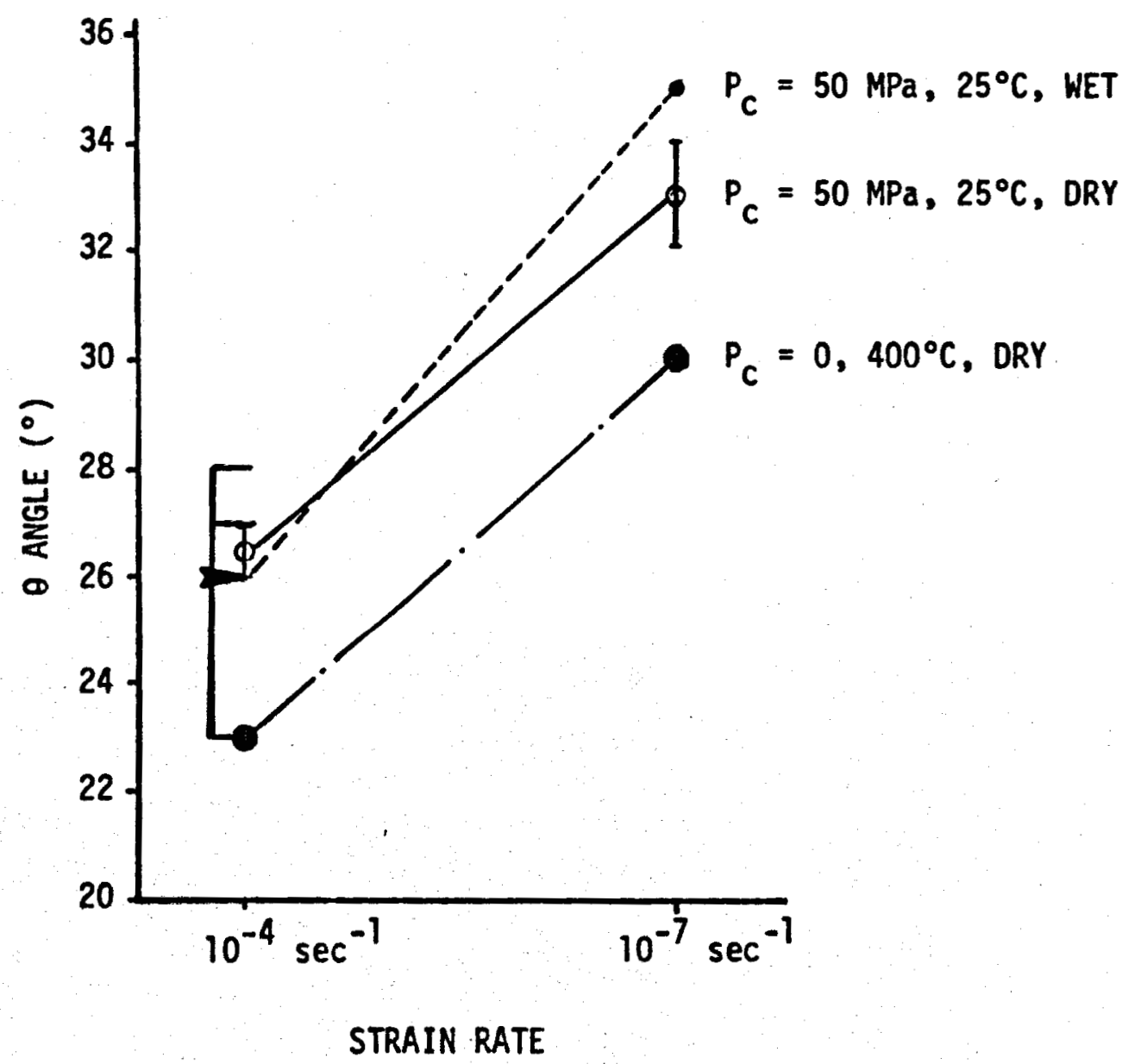

Figure 14. Plot of $\theta$, the angle between fault surface and $\sigma_{1}$ across boundaries of specimen, against strain rate. 
Figure 15. Specimens show that fracture is the major mechanism of deformation in both the granodiorite and andesite to temperatures $\geq$ $1000^{\circ} \mathrm{C}$.

(a) Photograph of two specimens of granodiorite in their copper jackets. Outlines of macrofractures in copper clearly show the deformation of this rock still is brittle at $920^{\circ}$ and $1000^{\circ} \mathrm{C}$. Cylinders are $4.0 \mathrm{~cm}$ long.

(b) Polished section of specimen No. 87, deformed dry and unconfined at $1000^{\circ} \mathrm{C}$, shows a fault zone consisting of coalesced, en echelon extension fractures. Cylinder is $4.0 \mathrm{~cm}$ long.

(c) Photomicrograph of a right-lateral fault zone in granodiorite specimen No. 132 , deformed dry at $50 \mathrm{MPa}$ and $1000^{\circ} \mathrm{C}$. The long axis of the picture corresponds to the orientation of $\sigma$ across the boundaries of the specimen during deformation. Espectally conspicuous are microscopic feather fractures in the host feldspar grains immediately adjacent to the shear zone. Crossed-polarized light. Scale line is $0.05 \mathrm{~mm}$.

(d) Photomicrograph shows microfractures in feldspar phenocryst and finer-grained groundmass of the andesite have the same orientation and configuration in this specimen (No. 85) deformed at $1000^{\circ} \mathrm{C}$ as they do in specimens deformed at $25^{\circ}, 400^{\circ}$, or $700^{\circ} \mathrm{C}$. Plane polarized light, Scale line is $0.5 \mathrm{~mm}$. 


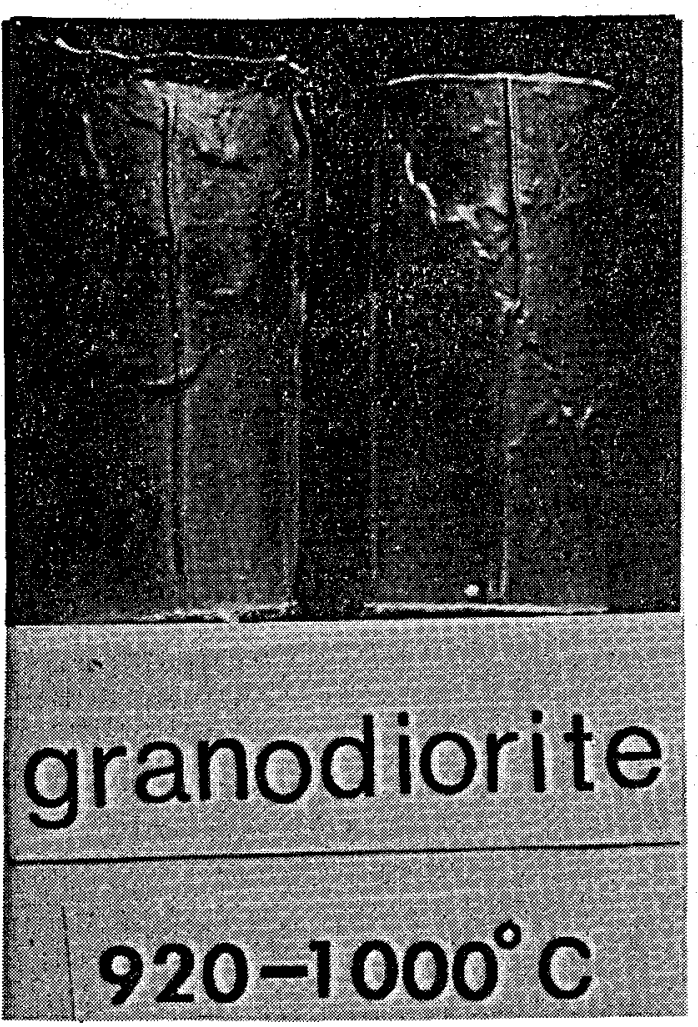

a

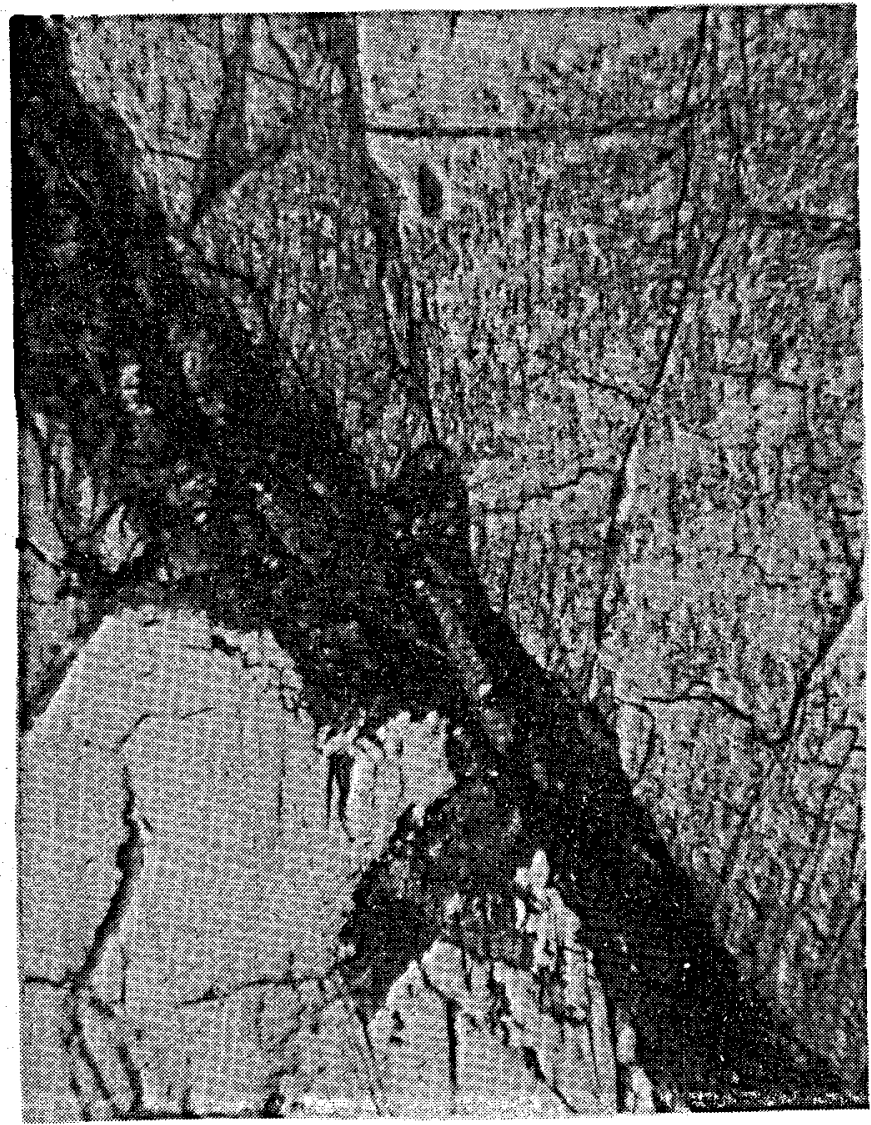

C

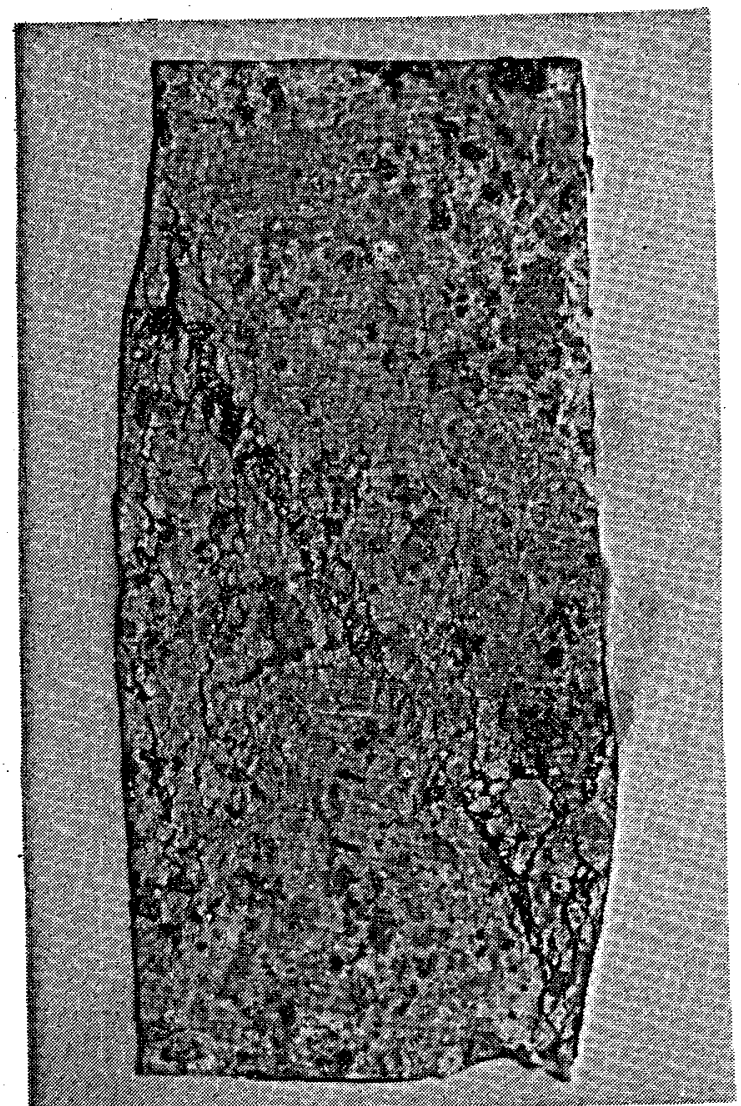

b

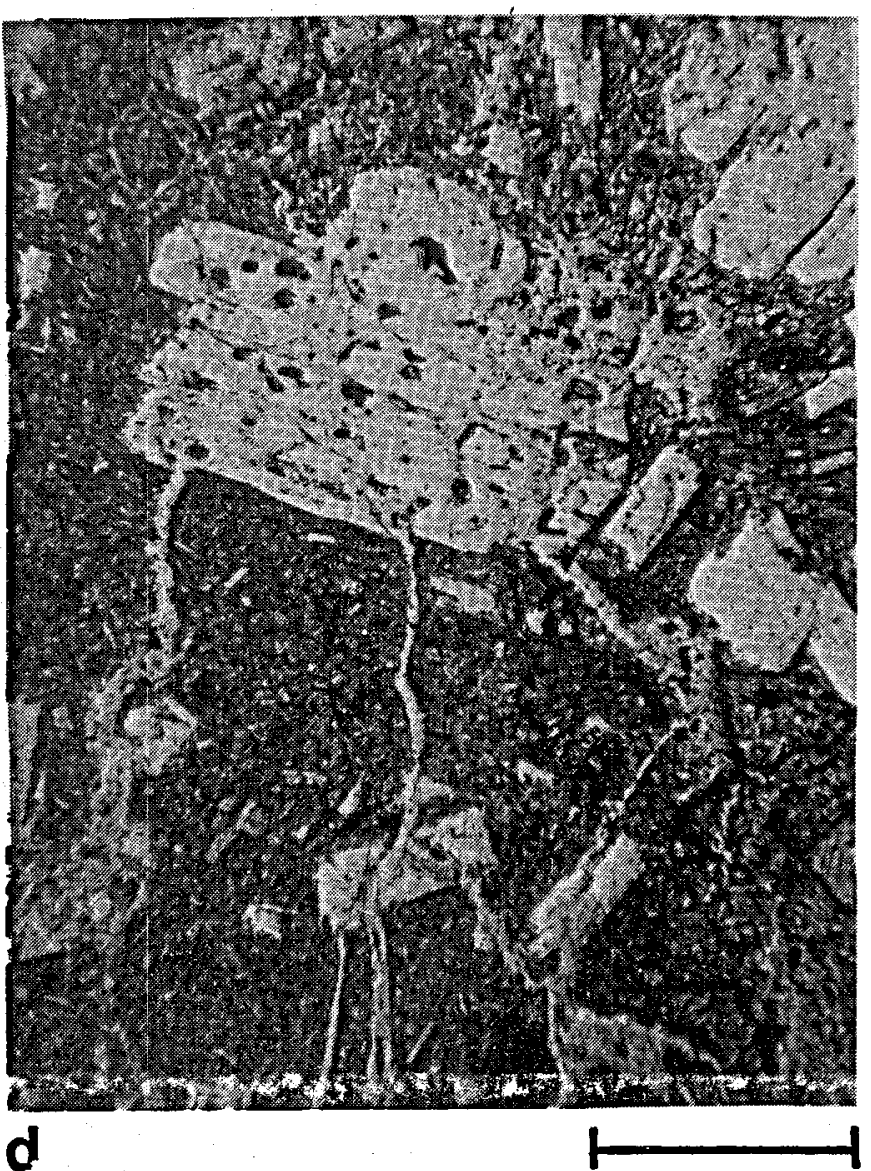


Figure 16. Photomicrographs show brittle deformation of the Mount Hood Andesite at $700^{\circ} \mathrm{C}$, confining pressures to $50 \mathrm{MPa}$, and at a strain rate of $10^{-4} \mathrm{sec}^{-1}$. (a) Specimen 36 , deformed unconfined, shows traces of macroscopic extension (vertical) and shear fractures (inclined, see arrow). (b) Specimen 35, deformed at $50 \mathrm{MPa}$, shows an incipient fault zone (see outlined zone) details of which are shown in (c, $d$, and $e$ ). Microfractures (arrows) in Specimen 35 are subparallel to the greatest principal stress $\left(\sigma_{1}\right)$ across the boundaries of the specimen and lie en-echelon arrangement along the fault zone (b). They cross phenocrysts and glassy ground mass without major change in direction. Plane polarized light. Scale line for ( $a$ and $b$ ) is $1.0 \mathrm{~cm}$, that for $(c, d$, and $e$ ) is $0.05 \mathrm{~cm}$. 

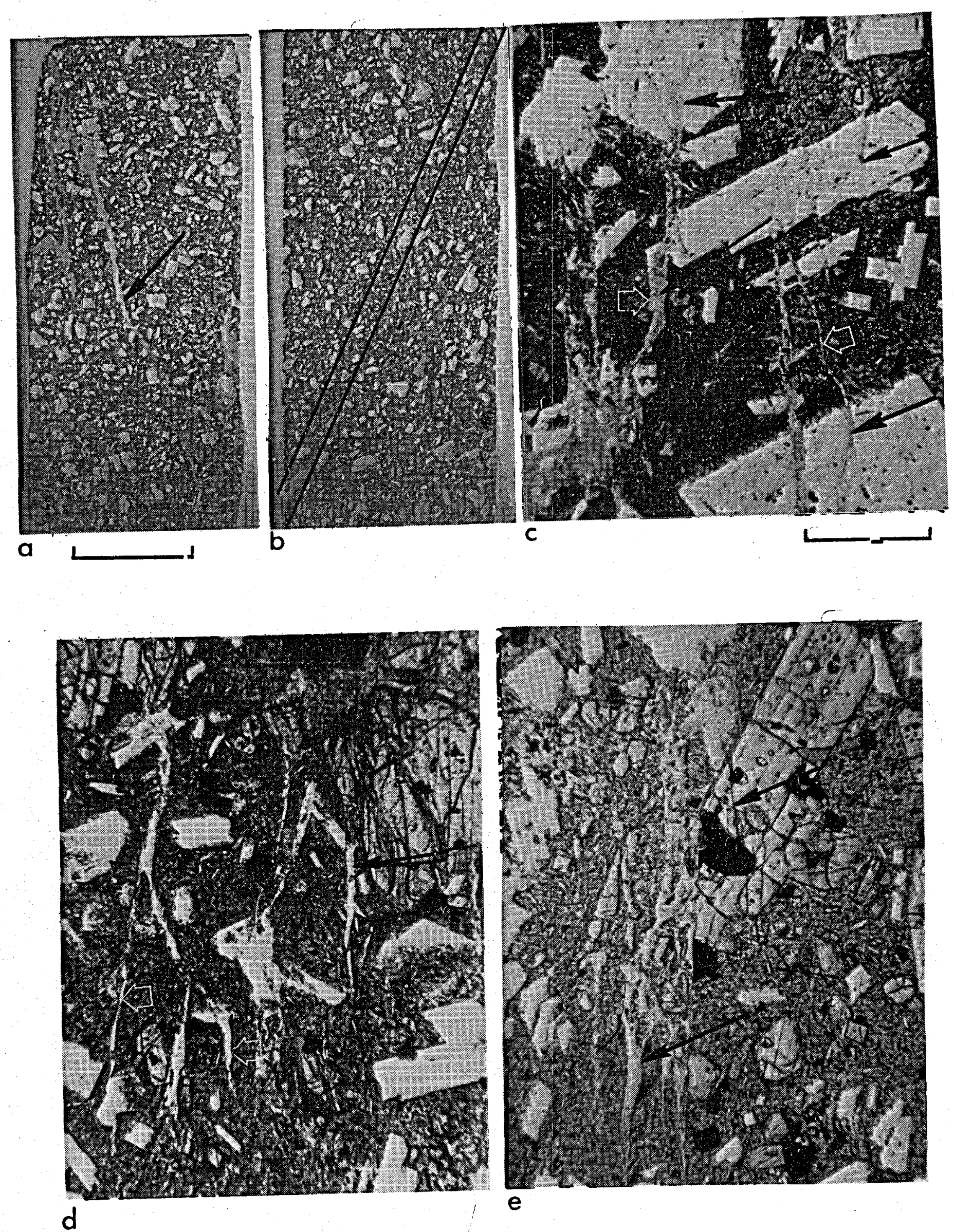
thermal treatment.) Data for all three crystalline rocks are similar, and those shown for the granodiorite and andesite are representative (Figures 17 and 18, respectively).

Clearly, the total number of both load-induced and thermal cracks increases with increasing temperature, about equally for all three rocks, and in the andesite about equally in the very-fine grained groundmass and in the phenocrysts. The increase in microfracture density of about 5 per $\mathrm{mm}$ from that in the starting material to that in specimens deformed at room temperature is essentially identical to that in the Westerly Granite under similar experimental conditions (Tapponnier and Brace, 1976, Figure 3). Subtracting the amount of thermal cracking from the total abundances of microfractures (Figure 17), reveals that the degree of microfracturing caused by loading alone is about the same at all temperatures up to $1000^{\circ} \mathrm{C}$, above which partial melting occurs and thermal cracking increases dramatically (not shown in the figure where up to $1000^{\circ} \mathrm{C}$ the increase is linear).

The work-softening exhibited by many of the specimens (Figures 3-5, and 9) occurs during displacements along the macroscopic faults. Thinsection observations reveal that this softening is accompanied by local ductile flow in the groundmass of the andesite, the development of microscopic feather fractures and of gouge, and kinking of favorably oriented biotite and other types of gliding flow in mafic minerals immediately adjacent to the faults. Some of these same mechanisms, along with thermal alteration of hornblende, biotite and pyroxene, probably also operate prior to macroscopic failure. However, in light of the strength and ductility trends, these mechanisms, if significantly influential at all, apparently contribute more to the weakening of the rocks than to the enhancement of their ductility, for virtually all of the permanent 


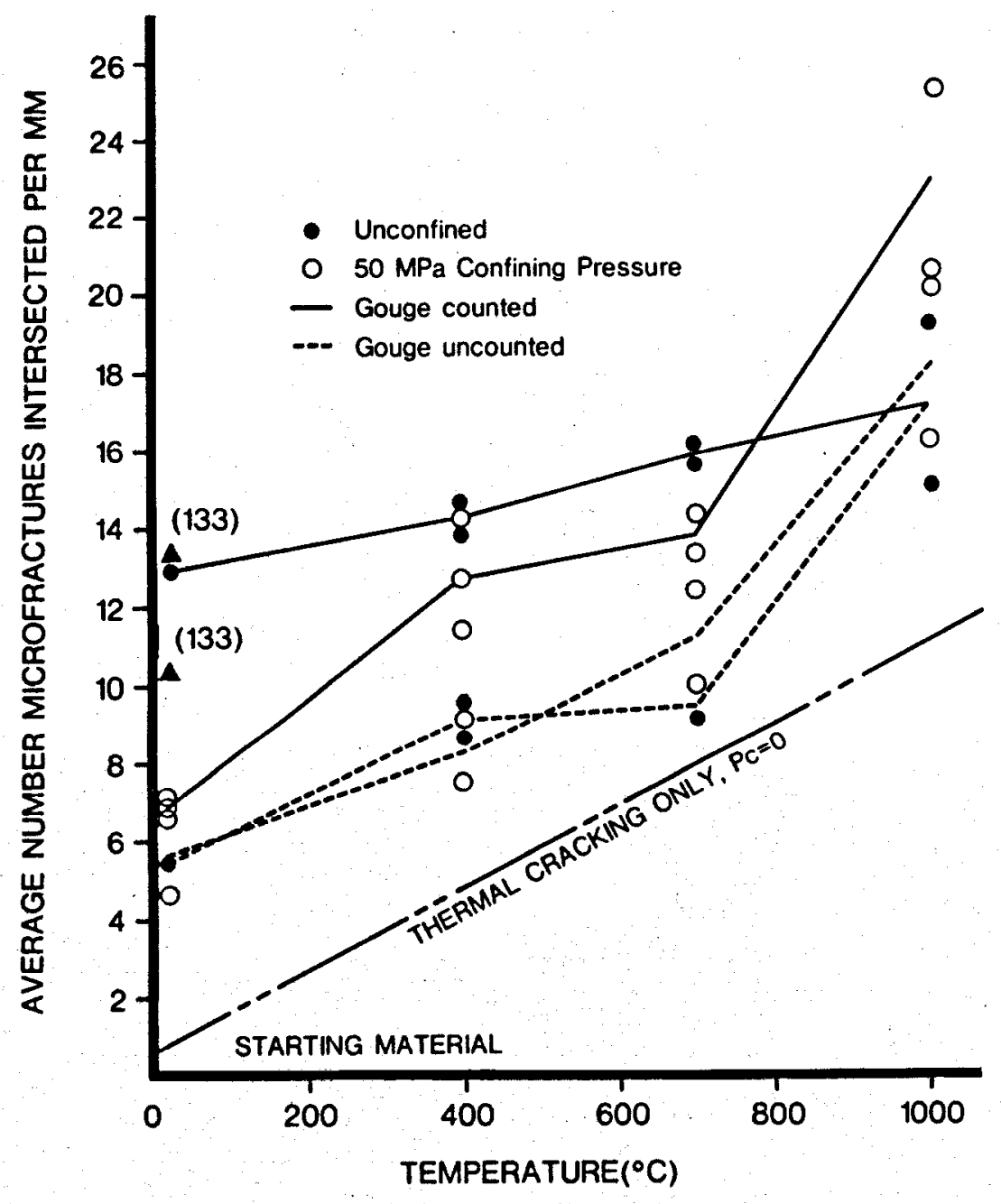

Figure 17. Microfracture abundance as functions of pressure and temperature in deformed, room dry Charcoal Granodiorite. Specimen 133 ( $\Delta$ ) was heated to $1000^{\circ} \mathrm{C}$, then cooled and deformed at $25^{\circ} \mathrm{C}, 50 \mathrm{MPa}$; the higher result includes gouge, and lower one does not. 


\section{MT HOOD ANDESITE}
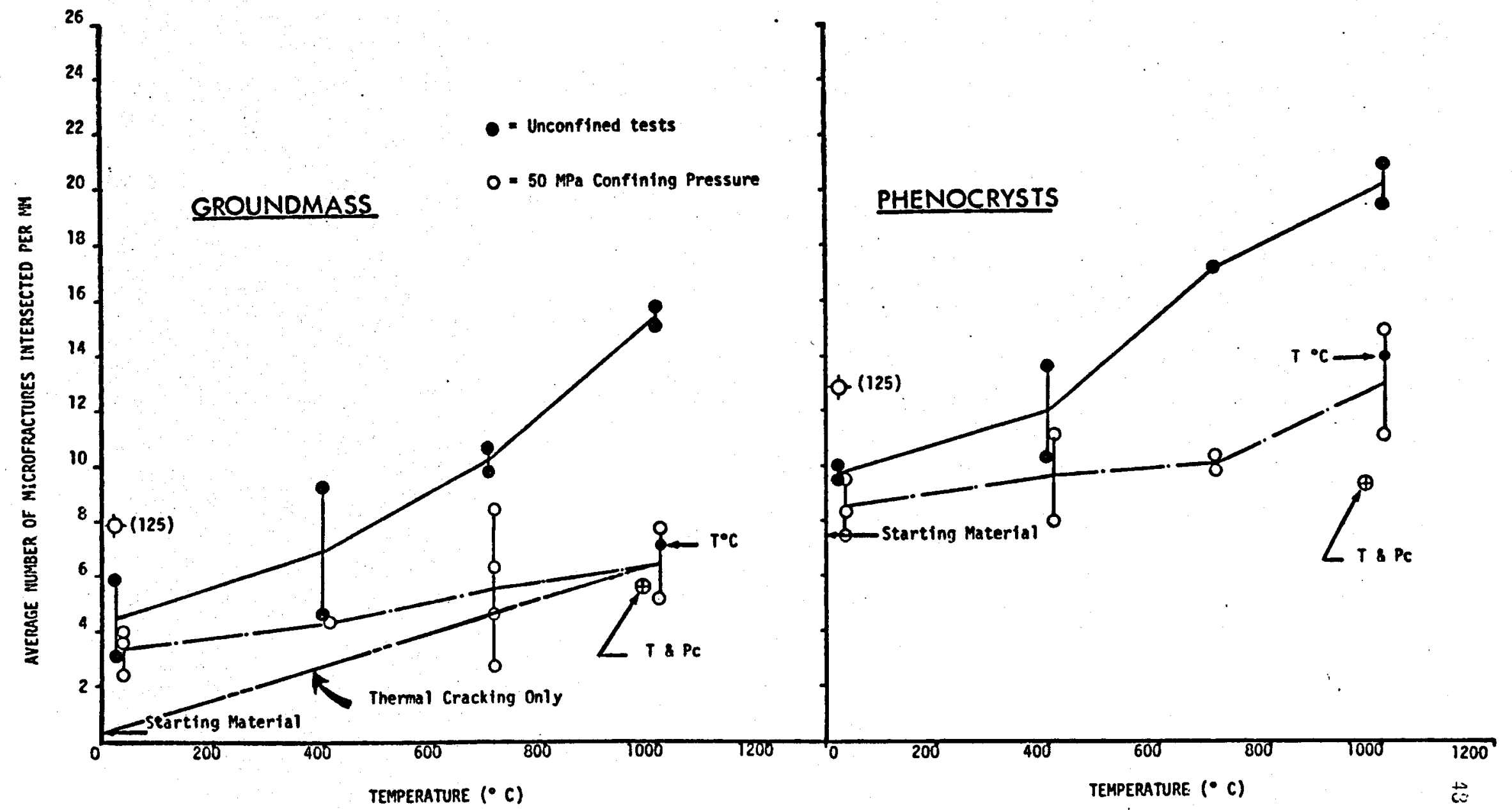

Figure 18. Relations between microfracture abundance and temperature for hypocrystalline goundmass and phenocrysts in Mt. Hood Andesite, deformed dry at $10^{-4} \mathrm{sec}^{-1}$ and at 0 and $50 \mathrm{MPa}$ confining pressures. 
shortening is accountable to the macroscopic faulting in the brittle regime, even at $1000^{\circ} \mathrm{C}$.

Partial Melting

The partial melting in the andesite and granodiorite rocks (Figures 19-22) produces two types of glass. Under the microscope in transmitted light, one is brownish-amber exhibits flow-banding, contains relatively few bubbles (Figure 20). Crystallites produced upon devitrification are common (Figure 21). The other glass is colorless and highly vesicular, and flow herein produces elongated vesicles (Figure 20). In granodiorite specimens with ancipient partial melting the amber glass, clearly derived from the hornblende occurs first as the temperature rises, i.e., the hornblende melts at a lower temperature than does the quartz, feldspar or other mafics (Figure 21a). Electron-microprobe analyses by Drs. P. F. Hlava and E. J. Graeber of Sandia Laboratories confirm the petrologic evidence that the brownish-amber and clear glasses arise from melting of mafic minerals and feldspar, respectively (Table 6). 


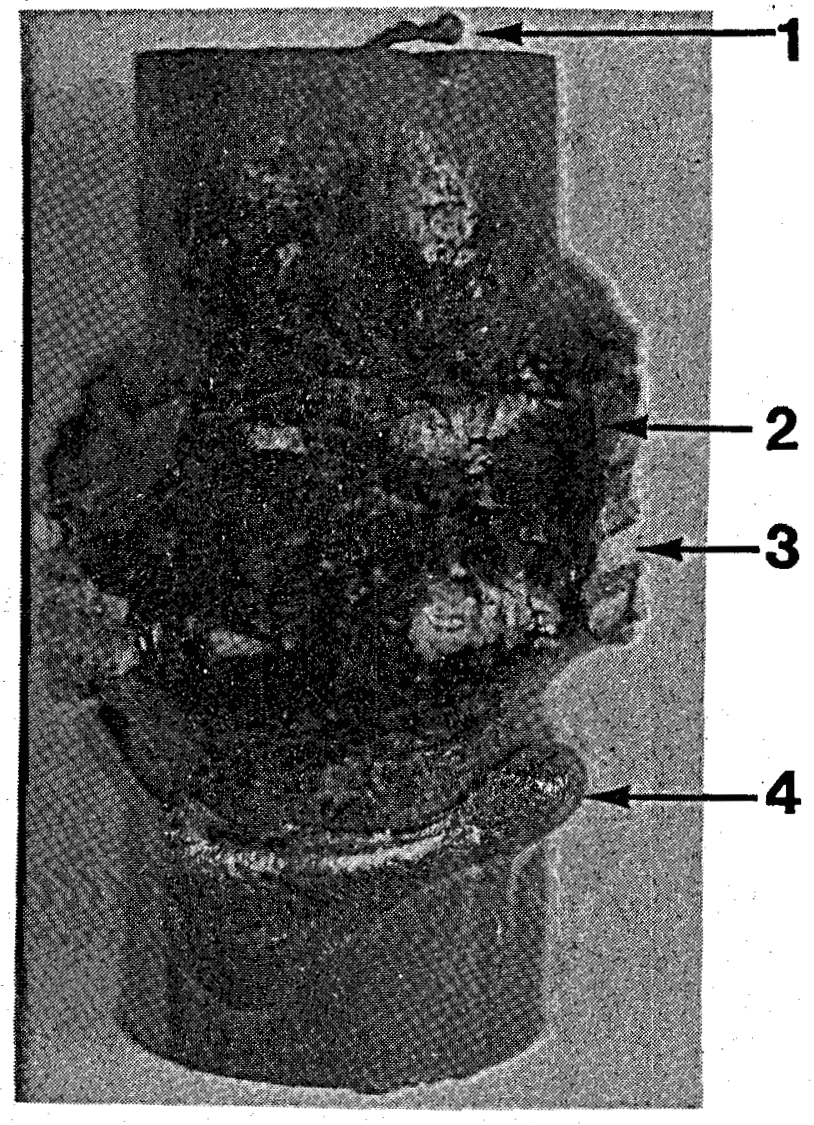

Figure 19. Photograph shows partially melted specimen of Mt. Hood Andesite. Item (1) is upper thermocouple wire, (2) glass, (3) furnace windings and ceramic, and (4) mel ted copper jacket. Specimen is about $4.0 \mathrm{~cm}$ long. Microscopic details are shown in Figure 22. 


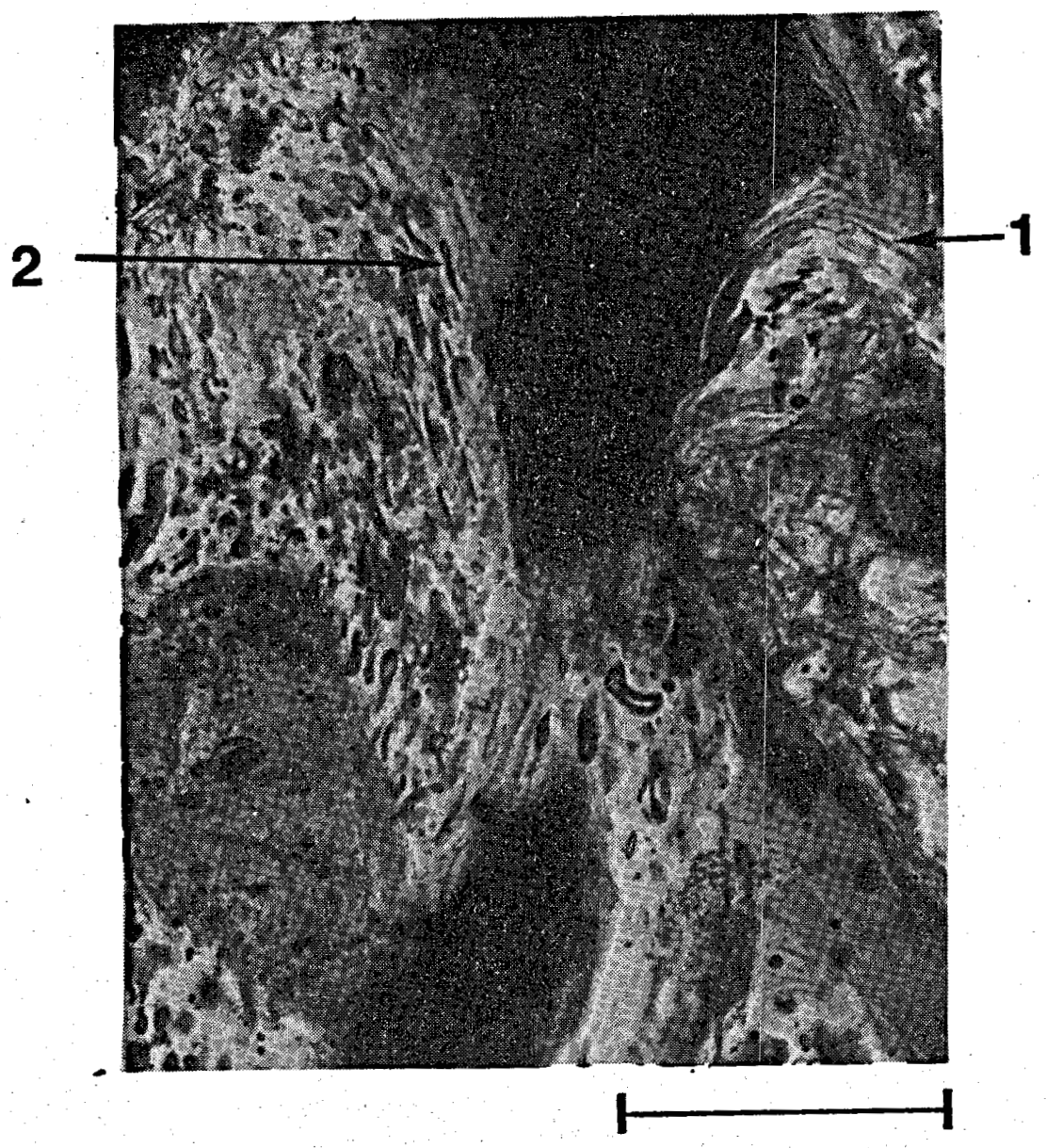

Figure 20. Photomicrograph of flow in two glasses formed during partial melting and deformation of Charcoal Granodiorite. Item (1) is flow banding in amber glass; (2) elongated vesicules in colorless glass. Plane-polarized light; scale tine is $0.25 \mathrm{~mm}$. 

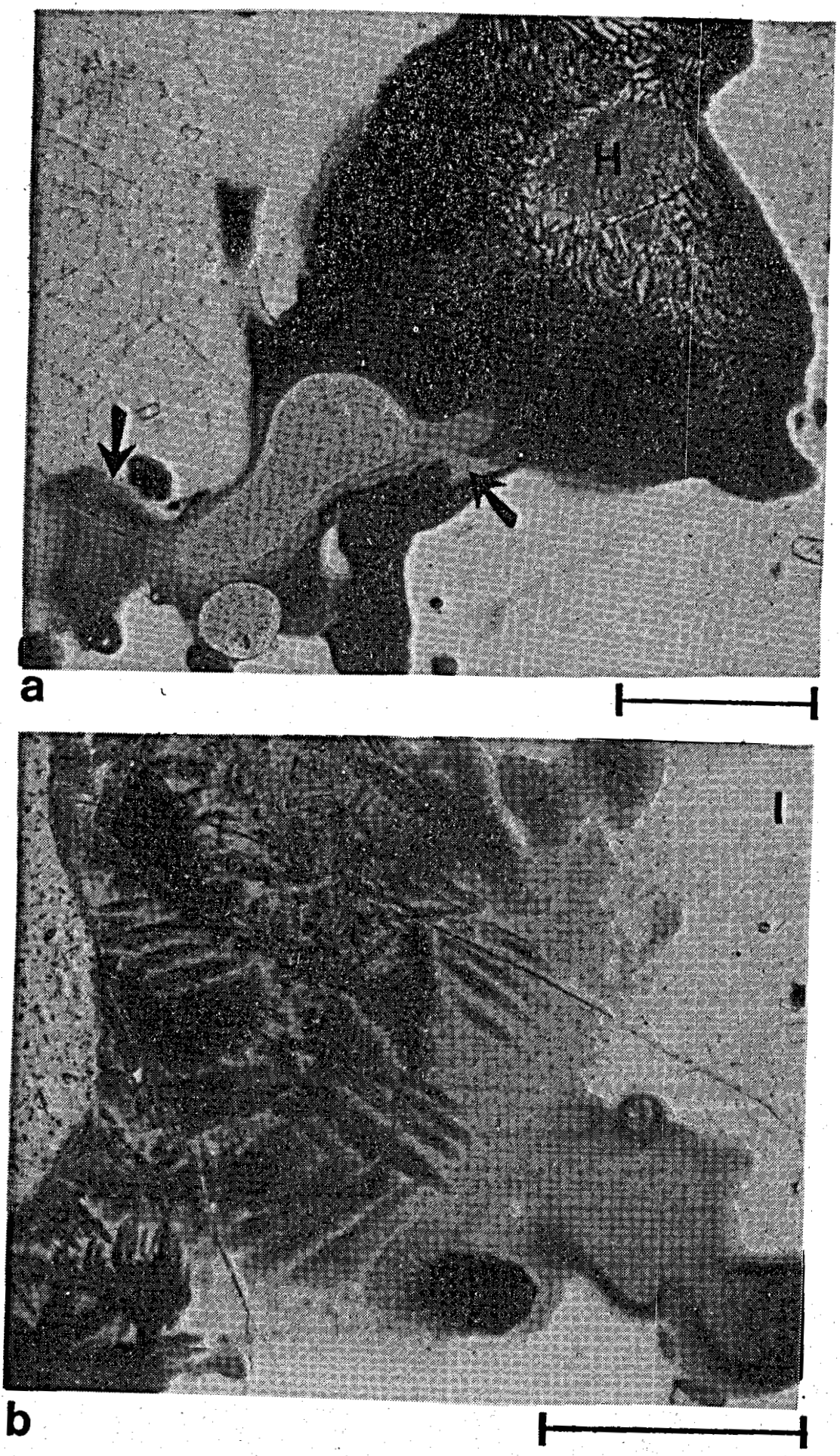

Figure 21. Photomicrographs of amber glass development in Charcoal Granodiorite. (a) View shows relation between original hornblende grain (H), altered hornblende, opaque oxidized zone, and amber glass with devitrified crystallines (arrow). (b) Example of crystallines formed upon devitrification of glass. Plane-polarized light, scale lines are $0.5 \mathrm{~mm}$ for (a) and $0.25 \mathrm{~mm}$ for (b). 

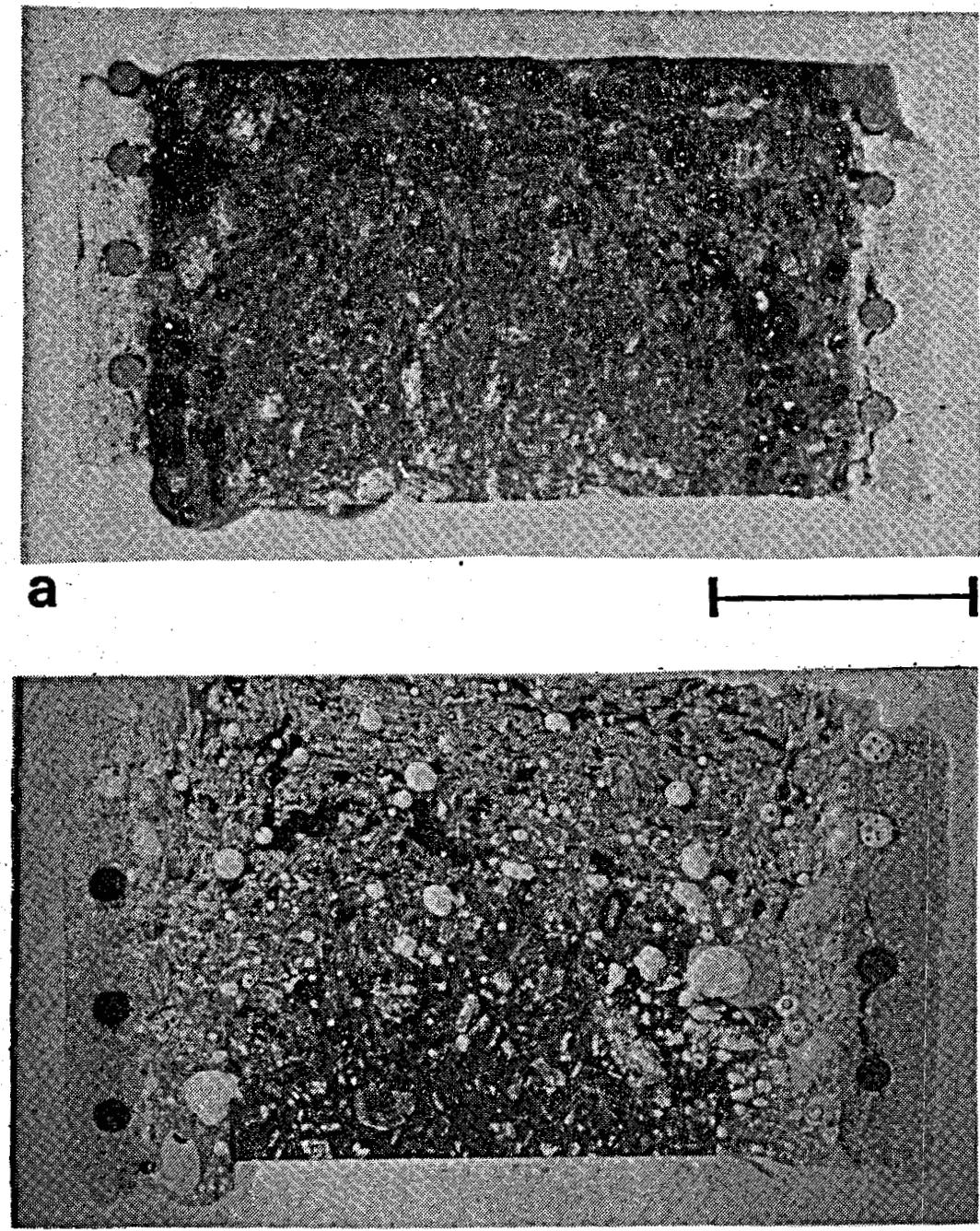

b

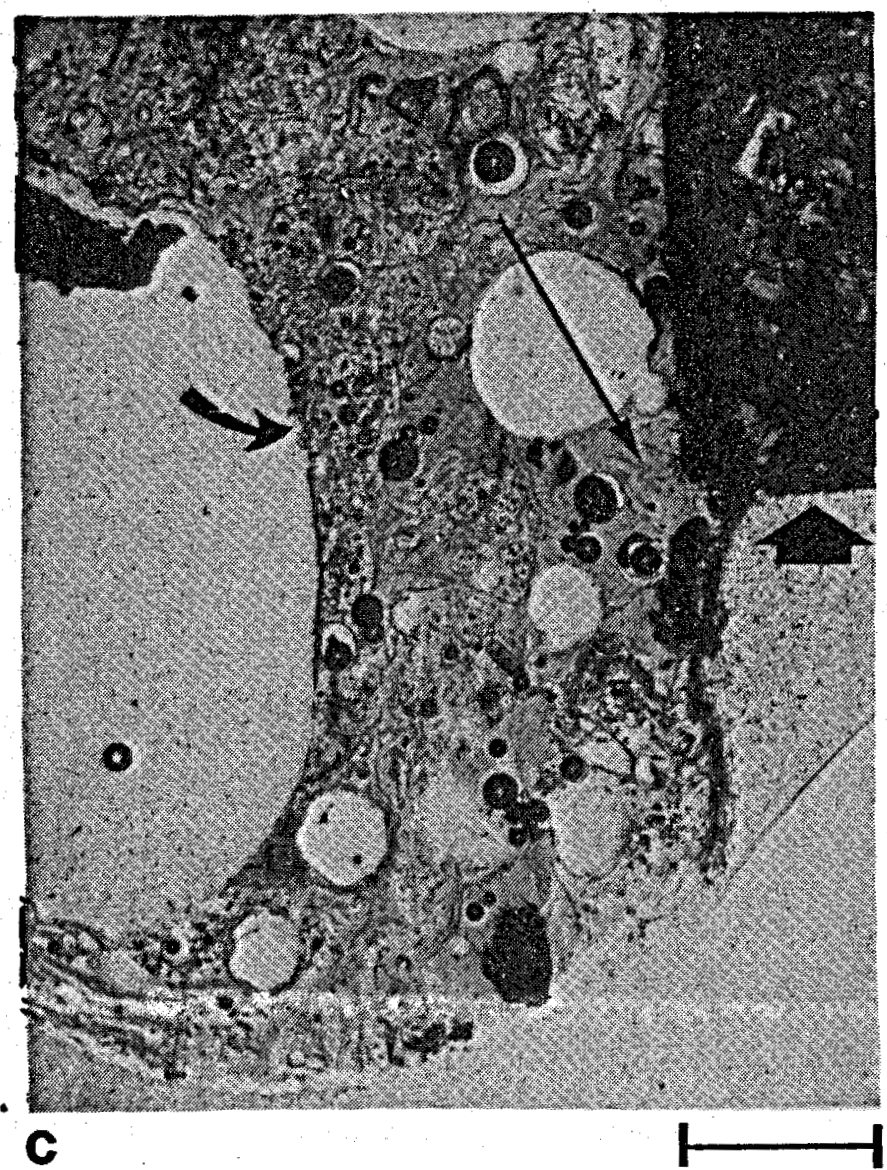

Figure 22. Photomicrographs of partially melted Mt. Hood Andesite. (a) Reflected light view of polished surface shows vesicular melted zone, ceramic furnace and furnace wires. (b) Thin section view of same areas as (a) shows melted zones surrounding darker unmelted area. Opaque areas are oxidized iron-rich minerals biotite and hornblende. Vesicles and furnace are conspicuous. (c) Detail of lower left corner of (b) shows unmelted rock (short arrow), amber glass (straight arrow), highly vesicular colorless glass (curved arrow), and large vesicules. Scale lines are $7.5 \mathrm{~mm}$ in ( $a$ and $b$ ) and $0.5 \mathrm{~mm}$ for (c). Plane-polarized light. 
Table 6. Electron Microprobe Analysis ${ }^{1}$ of Two Glasses from Partially Melted Mount Hood Andesite and Charcoal Granodiorite.

\begin{tabular}{|c|c|c|c|c|}
\hline & \multicolumn{2}{|c|}{ Mount Hood Andesite } & \multicolumn{2}{|c|}{ Charcoal Granodiorite } \\
\hline & $\begin{array}{l}\text { Brown } \\
\text { Glass }\end{array}$ & $\begin{array}{c}\text { Colorless } \\
\text { Glass }\end{array}$ & $\begin{array}{l}\text { Brown } \\
\text { Glass }\end{array}$ & $\begin{array}{c}\text { Colorless } \\
\text { Glass }\end{array}$ \\
\hline & Wt. $\%$ & Wt. \% & Wt. \% & Wt. $\%$ \\
\hline $\mathrm{SiO}_{2}$ & 55.95 & 62.78 & 58.35 & 62.38 \\
\hline $\mathrm{TiO}_{2}$ & 2.15 & 1.17 & 1.37 & 0.95 \\
\hline $\mathrm{Al}_{2} \mathrm{O}_{3}$ & 9.82 & 13.74 & 10.28 & 15.58 \\
\hline $\mathrm{FeO}$ & 12.46 & 6.96 & 9.52 & 2.88 \\
\hline Mno & 0.24 & 0.09 & 0.18 & 0.05 \\
\hline MgO & 8.48 & 3.26 & 5.93 & 1.87 \\
\hline $\mathrm{CaO}$ & 4.57 & 5.50 & 6.42 & 4.42 \\
\hline $\mathrm{Na}_{2} \mathrm{O}$ & 3.13 & 4.20 & 3.40 & 4.79 \\
\hline $\mathrm{K}_{2} \mathrm{O}$ & 1.00 & 1.46 & 4.04 & 7.05 \\
\hline $\mathrm{P}_{2} \mathrm{O}_{5}$ & 0.46 & 0.38 & 0.32 & 0.26 \\
\hline Others & 1.74 & 0.46 & 0.19 & 0.08 \\
\hline
\end{tabular}

1. Analyses made at the Sandia Laboratories by P. F. Hlava, courtesy of E. J. Graeber. 


\section{BOREHOLE STABILITY}

\section{Borehole Stresses}

Ideally borehole stresses depend on the regional state of stress in the undisturbed rock, and this is not generally know a priori. Few measurements of the in-situ stress have been made in crystalline igneous rocks at depths of more than a few meters (Table 7). Using the hydrauticfracturing technique, the staff of the Los Alamos Scientific Laboratory has determined the stress at a depth of $2926 \mathrm{~m}$ in the Precambrian crystalline basement of the Jemez Mountains in connection with its experiment on geothermal-energy extraction from dry hot rock. Taken as the weight per unit area of the superincumbent rock, the vertical stress, $\sigma_{v}$, is $72 \mathrm{MPa}$, and the minimum horizontal stress, $\sigma_{h}$, is $34 \mathrm{MPa}$ (Brown, 1976). Hydraulicfracturing tests by Haimson (1976), and Haimson and Voight (1977) in granitic rocks in the United States and basalt in Iceland, respectively, reveal that the horizontal stresses may be greater or less than the vertical stresses at depths in the range of 100 to $400 \mathrm{~m}$. Strain-relief measurements in a South African dunite disciose an average horizontal stress at 350 m that greatly exceeds the overburden stress (Gay, 1975).

Since available data are too few for meaningful generalizations, we cannot predict the ratios of vertical to horizontal stresses elsewhere. For simplicity let us assume, therefore, that all horizontal stresses are equal and that $\sigma_{v} / \sigma_{h}$ is $0.5,1$, or 2 . Values falling much outside these extremes are unitikely, albeit possible. 
TABLE 7. SOME IN-SITU STRESS MEASUREMENTS IN IGNEOUS ROCKS

\begin{tabular}{|c|c|c|c|c|c|c|}
\hline PLACE & ROCK & $\begin{array}{l}\text { DEPTH } \\
(M)\end{array}$ & $\begin{array}{c}\text { VERTICAL } \\
\text { (OVERBURDEN) }\end{array}$ & $\begin{array}{c}\text { STRESSES (MPa) } \\
\text { MAXIMUM } \\
\text { HORIZONTAL }\end{array}$ & $\begin{array}{l}\text { MINIMUM } \\
\text { HORIZONTAL }\end{array}$ & REF. \\
\hline CALIFORNIA & GRANITE & 300 & 8.2 & 9.5 & 5.4 & Haimson, 1976 \\
\hline S. CAROLINA & GRANITE & 230 & 6.2 & 22.8 & 15.9 & Haimson, 1976 \\
\hline WISCONSIN & GRANITE & 136 & 3.5 & 16.0 & 7.0 & Haimson, 1976 \\
\hline N. MEXICO & GRANITE & 2926 & 71.7 & $?$ & 34.1 & Brown, 1976 \\
\hline ICELAND & BASALT & 203 & 5.4 & 6.3 & 4.1 & \multirow{3}{*}{$\begin{array}{l}\text { Haimson and } \\
\text { Voight, } 1977 \\
\text { Haimson and } \\
\text { Voight, } 1977 \\
\text { Gay, } 1975\end{array}$} \\
\hline ICELAND & BASALT & 375 & 10.0 & 7.0 & 6.4 & \\
\hline S. AFRICA & DUNITE & 350 & 11.5 & \multicolumn{2}{|c|}{15.5 (average) } & \\
\hline
\end{tabular}


At by far most locations where the complete in-situ stress tensor has been determined, $\sigma_{v}$ is indeed equivalent to the weight per unit area of the overburden and it lies in a principal plane or close to it (Haimson, 1976). Let us assume that before the rock is drilled the state of stress is

$$
\begin{aligned}
& \sigma_{x}=\sigma_{y}=\sigma_{h} \\
& \sigma_{z}=\rho_{r} g z=\sigma_{v} \\
& \sigma_{h}=b \sigma_{v},
\end{aligned}
$$

where $b=0.5,1$, or $2 ; z(m)$ is depth below the free surface; $\rho_{r}\left(\mathrm{~kg} / \mathrm{m}^{3}\right)$ is the average bulk density of the overburden; $g\left(\mathrm{~m} / \mathrm{s}^{2}\right)$ is acceleration of gravity; and compressive stresses (MPa) are counted positive.

In cylindrical coordinates (Figure 23) the vertical axial stress, $\sigma_{z}^{\prime}$, and the horizontal radial and tangential stresses, $\sigma_{r}^{\prime}$ and $\sigma_{\dot{\theta}}^{\prime}$, in the undisturbed rock are in general

$$
\begin{aligned}
& \sigma_{r}^{\prime}=\frac{\sigma_{x}+\sigma_{y}}{2}+\frac{\sigma_{x}-\sigma_{y}}{2} \cos 2 \theta \\
& \sigma_{\theta}^{\prime}=\frac{\sigma_{x}+\sigma_{y}}{2}-\frac{\sigma_{x}-\sigma_{y}}{2} \cos 2 \theta \\
& \sigma_{z}^{\prime}=\rho_{r} g z,
\end{aligned}
$$

where the angle $\theta$ is measured counterclockwise from the $x$ direction, and $\sigma_{x}>\sigma_{y}$

Now suppose that a vertical, perfectly cylindrical hole is drilled into the stressed mass of dry, statistically homogeneous and isotropic, ideally elastic rock. The original far-field stresses are perturbed in 


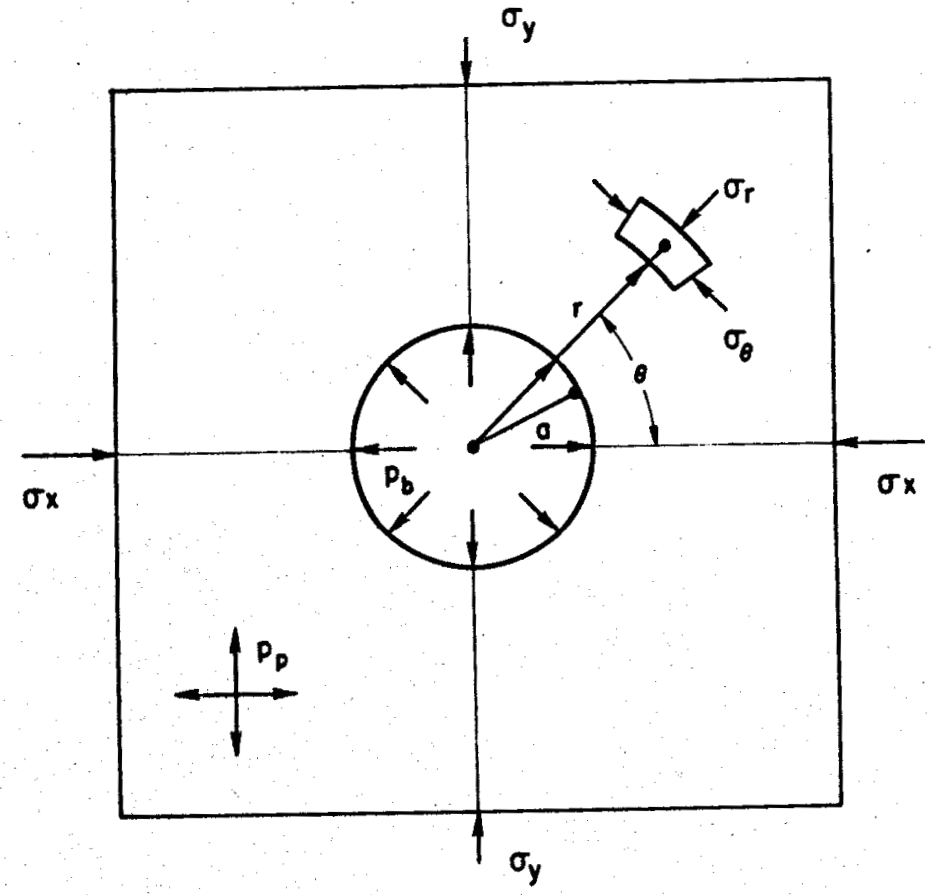

Figure 23. Radial and tangential stresses, $\sigma_{r}$ and $\sigma_{\theta}$, around a cylindrical hole of radius, $a$, in an elastic, isotropic plate. Far-field horizonti stresses are $\sigma_{x}>\sigma_{y}$; vertical stress is $\sigma_{z}$. Borehole fluid pressure is $\mathrm{P}_{b}$, and pore pressure in a. porous medium is $\mathrm{P}_{\mathrm{p}}$. 
the vicinity of the hole where the new stresses can be computed from the Kirsch equations (see, for example, Timoshenko and Goodier, 1970, p. 9093).

$$
\begin{aligned}
& \sigma_{r}=\frac{\sigma_{x}+\sigma_{y}}{2}\left(1-\frac{a^{2}}{r^{2}}\right)+\frac{\sigma_{x}-\sigma_{y}}{2}\left(1-\frac{4 a^{2}}{r^{2}}+\frac{3 a^{4}}{r^{4}}\right) \cos 2 \theta \\
& \sigma_{\theta}=\frac{\sigma_{x}+\sigma_{y}}{2}\left(1+\frac{a^{2}}{r^{2}}\right)-\frac{\sigma_{x}-\sigma_{y}}{2}\left(1+\frac{3 a^{4}}{r^{4}}\right) \cos 2 \theta,
\end{aligned}
$$

where $a$ is the radius of the hole and $\sigma_{x}$ and $\sigma_{y}$ are the original farfield stresses. Since we are concerned with the stresses at the wall, let $r=a$. Then

$$
\begin{aligned}
& \sigma_{r}=\tau_{r \theta}=0 \\
& \sigma_{\theta}=\sigma_{x}+\sigma_{y}-2\left(\sigma_{x}-\sigma_{y}\right) \cos 2 \theta .
\end{aligned}
$$

The stress changes in plane strain are

$$
\begin{aligned}
& \Delta \sigma_{r}=\sigma_{r}-\sigma_{r}^{\prime}=-\left(\frac{\sigma_{x}+\sigma_{y}}{2}\right)+\left(\frac{\sigma_{x}-\sigma_{y}}{2}\right) \cos 2 \theta \\
& \Delta \sigma_{\theta}=\sigma_{\theta}-\sigma_{\theta}^{\prime}=\frac{\sigma_{x}+\sigma_{y}}{2}-\frac{3\left(\sigma_{x}-\sigma_{y}\right)}{2} \cos 2 \theta \\
& \Delta \sigma_{z}=v\left(\Delta \sigma_{r}+\Delta \sigma_{\theta}\right)=-2 v\left(\sigma_{x}-\sigma_{y}\right) \cos 2 \theta,
\end{aligned}
$$

where $v=$ Poisson's ratio, about 0.25 for rock.

Adding these stress changes to the initial stresses (equation 6), assuming that $\sigma_{x}=\sigma_{y}=\sigma_{h}$ (equation 5), and solving for the maximum values at $\cos 2 \theta=1$ gives

$$
\begin{aligned}
& \sigma_{r}=0 \\
& \sigma_{\theta}=2 \sigma_{h} \\
& \sigma_{z}=\rho_{r} g z .
\end{aligned}
$$


Since $\tau_{r \theta}=0$, these are principal stresses.

For an average bulk density, $\rho_{r}=2.7 \times 10^{3} \mathrm{~kg} / \mathrm{m}^{3}$, the vertical stress, $\sigma_{z}$, increases at the rate of $27 \mathrm{MPa} / \mathrm{km}$.

Al though well completions at near-magmatic temperature may require work in an open hole, let us suppose that a hydrostatic borehole pressure, $p_{b}$, can be maintained by a drilling fluid which cannot penetrate the surrounding impermeable rock. Then the stresses are

$$
\begin{aligned}
& \sigma_{r}=p_{b} \\
& \sigma_{\theta}=2 \sigma_{h}-p_{b} \\
& \sigma_{z}=\rho_{r} g z .
\end{aligned}
$$

Conventional, heavy, oil-well drilling muds can be formulated for a density as high as $2 \times 10^{3} \mathrm{~kg} / \mathrm{m}^{3}$, but they are not stable at the high temperatures of concern, so we suppose that the hole is filled with water with a density close to $1 \times 10^{3} \mathrm{~kg} / \mathrm{m}^{3}$ at $25^{\circ} \mathrm{C}$. (The density is really less at high temperatures.) The borehole pressure, $p_{b}$, then increases at a rate of $10 \mathrm{MPa} / \mathrm{km}$.

All crustal rocks have finite porosity, owing to intergranular voids and intragranular microcracks, and commonly to unsealed macrofractures as we11. Let us suppose that these spaces are saturated with ground water under a hydrostatic pore-pressure, $p_{p}$, which increases at the rate

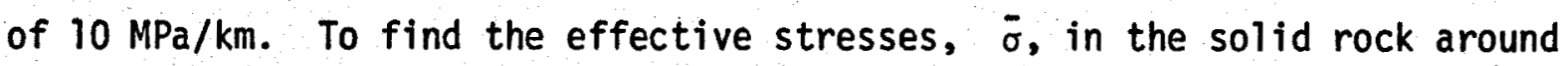
the open borehole, we subtract $p_{p}$ from all the normal stresses in equations 10 and 11 . The vertical stress, $\bar{\sigma}_{z}=\left(\rho_{r}-\rho_{w}\right) \mathrm{gz}$, increases at a rate of about $17 \mathrm{MPa} / \mathrm{km}$. 
Should the wallrock be permeable, the pore pressure in the vicinity of an open hole would bleed off, and the stresses would approach those given by equation 10. Around the water-filled well the pore pressure and borehole pressures would equalize, and the stresses would approach those given by equation 11 .

The principal stresses $\left(\sigma_{1}>\sigma_{2}>\sigma_{3}\right)$ given by equations 10 and 11 together with differential stresses, $\sigma_{1}-\sigma_{3}$, and mean stresses, $\sigma_{\mathrm{m}}=\sigma_{1}+$ $\left.\sigma_{2}+\sigma_{3}\right) / 3$, are given in Table 8 for the different ratios, $\sigma_{h} / \sigma_{v}$. Note that for a water-filled hole in water-saturated rock, the tangential stress can become tensile when the far-field horizontal stress is low relative to the overburden stress. This state of stress would favor unintentional hydraulic fracturing and lost circulation of the drilling fluid.

Our estimates of the borehole stresses should be regarded as minimal because the stresses are higher where $\sigma_{x} \neq \sigma_{y}$, as is commonly observed in nature, and because the walls of a real drillhole are not smooth, so that stress concentrations may be much higher than we have assumed ideally. On the other hand, thermoelastic stresses, introduced by temperature difference between borehole and country rock, have not been considered. If the borehole were cooler than the rock mass, the thermoelastic stresses would subtract from the differential stresses at the borehole wall and thus tend to stabilize the borehole.

Estimation of Borehole Stability

Dry Rocks. Recall that in the triaxial compression test the principal stresses are $\sigma_{1}>\sigma_{2}=\sigma_{3}=P_{c}$, whereas in the wall of the borehole, $\sigma_{1}>\sigma_{2}>\sigma_{3}$. In order to use the laboratory data to predict failure of 
TABLE 8. BOREHOLE STRESSES $(\mathrm{MPa} / \mathrm{km})$

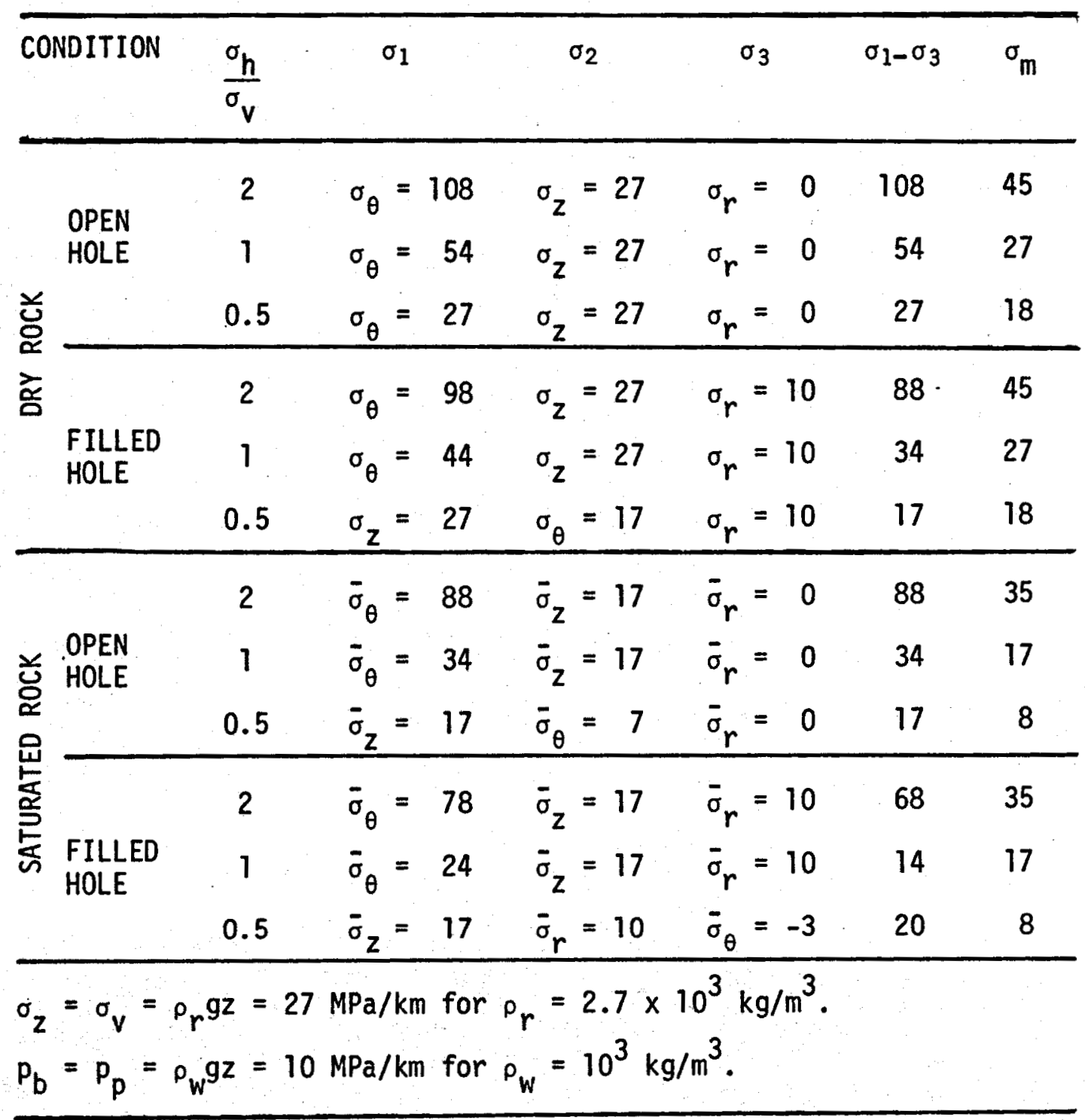


the borehole, we assume that ultimate compressive strength, $\sigma_{1}-\sigma_{3}$, at failure, is a function only of mean stress, $\sigma_{m}=\left(\sigma_{1}+\sigma_{2}+\sigma_{3}\right) / 3$, and temperature. We realize that this strength is not independent of the relative magnitude of the intermediate principal stress, $\sigma_{2}$, but we have measured it at three different confining pressures $\left(P_{C}=0,50\right.$, and 100 $\mathrm{MPa}$ ) and find it is linearly proportional to mean pressure. However, the effect of $\sigma_{2}$ is second-order (Handin et al., 1967), and the relation between strength and mean pressure is very nearly linear for many rocks in the brittle state (Handin and Hager, 1957; Borg and Handin, 1966). Given all the other uncertainties of the predictions, we regard this failure criterion as good an approximation as any proposed (Handin et al., 1967).

Figure 24 shows an example of one way to associate strength data with borehole failure. Using the quantities listed in Table 8 for dry rock $\left(p_{p}=0\right)$ and the ratio, $\sigma_{h} / \sigma_{v}=1$, we plot differential stress, $\sigma_{1}-\sigma_{3}$, as a function of mean pressure, $\sigma_{m}$, at the borehole wall for an open hole $\left(p_{b}=0\right)$ and a water-filled hole $\left(p_{b}=10 \mathrm{MPa} / \mathrm{km}\right)$ in impermeable rock. Choosing the proper stress gradients, $\sigma_{1}-\sigma_{3}=54$ and $34 \mathrm{MPa} / \mathrm{km}$, respectively, we relate the stresses to depth below the surface. At any given depth, the borehole pressure reduces the differential stress and so tends to stabilize the hole.

On this diagram of the borehole stresses as functions of depth, we superimpose the plots of ultimate compressive strength versus mean pressure, using the data of Table 1 and Figure 6 for dry andesite at temperatures of $25^{\circ}, 400^{\circ}, 700^{\circ}$, and $900^{\circ} \mathrm{C}$ and confining pressures of 0,50 , and $100 \mathrm{MPa}$. At a given mean pressure, say $50 \mathrm{MPa}$, the strengths exceed the borehole 


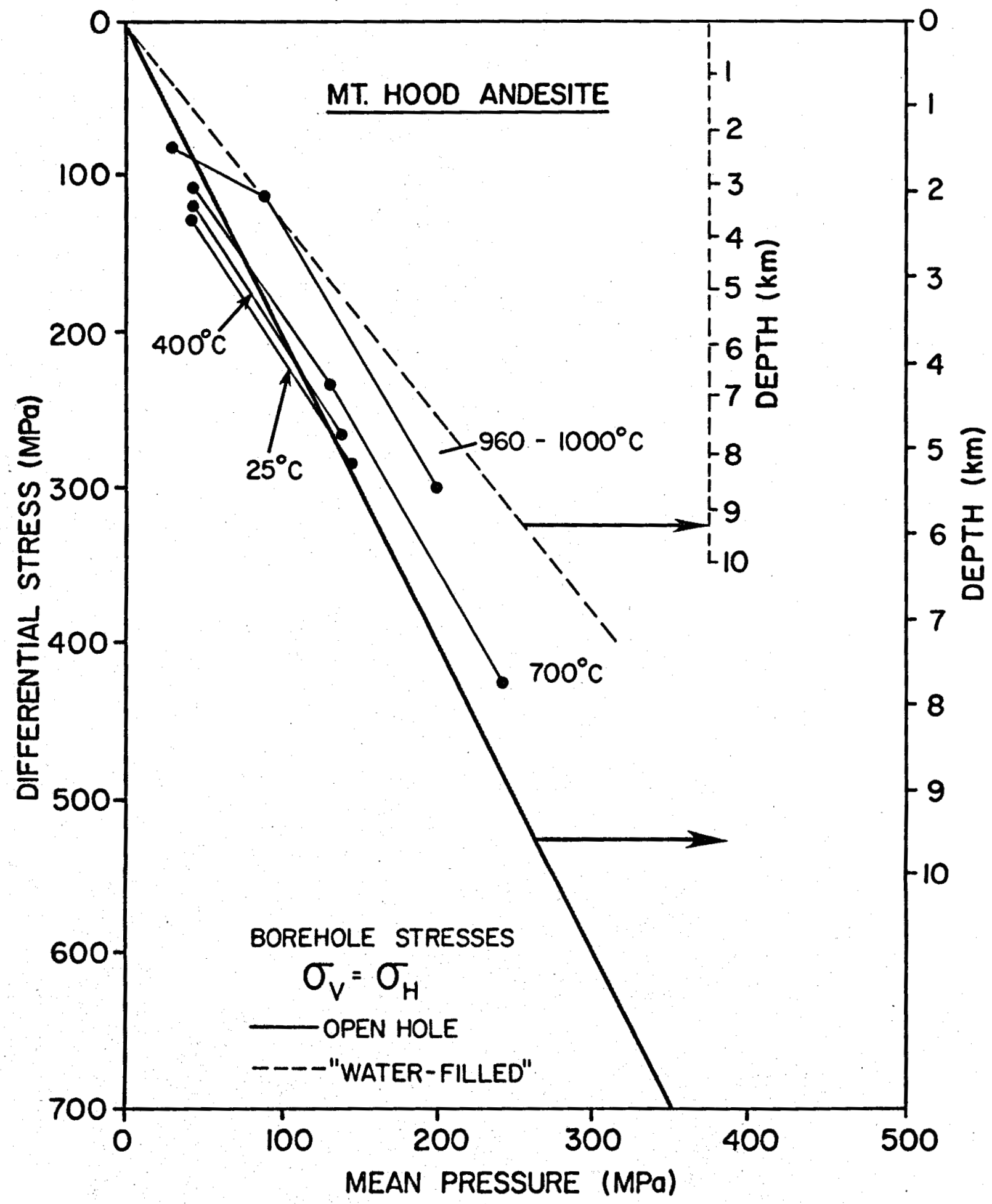

Figure 24. Assessment of borehole stability for dry Mt. Hood Andesite. Differential stress versus mean pressure at wall of an open hole (solid line and depth scale) and a "water"-filled hole (dashed line and depth scale) in impermeable rock. Superposed are ultimate compressive strength versus mean stress data. Each data point is the average of two or more tests at a given confining pressure and temperature. 
differential stress, so that even the open hole is stable at all temperatures. The intersections of the two sets of curves mark the boundaries between the fields of stability, containing all points to the left of the loci of borehole stresses, and of instability, containing all points on the right-hand side. Since the strength curves are subparallel to each other and to the borehole-stress curves, these boundaries are not sharp. Nevertheless, they can be related approximately to depth, about $5,4,3$, and $2 \mathrm{~km}$ at $25,400,700$, and $900^{\circ} \mathrm{C}$, respectively, for the open hole. The water-filled hole is stable at all temperatures to a depth of at least $10 \mathrm{~km}$. Similar data for the dry basalt and granodiorite are plotted in Figures 25 and 26 , respectively, and the maximum depth for stable boreholes in all three rocks are listed in Table 9 for a variety of conditions.

Examination of Figures 24-26 and Table 9 leads to certain generalizations concerning borehole stability based on the compressive strength data for the three dry crystalline rocks, namely:

1. The maximum depth for stable boreholes increases with decreasing temperature, decreasing $\sigma_{h} / \sigma_{v}$ ratio, and with filled versus open hole.

2. For $\sigma_{h} / \sigma_{v}=1.0$, boreholes filled with a medium whose average specific gravity is 1.0 will be stable in all three rocks to depths $\geq 10$ $\mathrm{km}$ at temperatures $>900^{\circ} \mathrm{C}$. The single exception is dry basalt that would fail at $5 \mathrm{~km}$ depth at temperatures $>900^{\circ} \mathrm{C}$ (Figure 25).

3. Open holes are much less stable. With $\sigma_{h} / \sigma_{v}=1.0$ borehole failures are likely at only 2 to $3 \mathrm{~km}$ depth if temperatures are $>900^{\circ} \mathrm{C}$. At $400^{\circ} \mathrm{C}$ the weakest rock (andesite) would begin to fail at $4 \mathrm{~km}$, and most would be stable to $>10 \mathrm{~km}$.

4. For dry rocks the $\sigma_{h} / \sigma_{v}$ ratio of 0.5 affords the greatest 


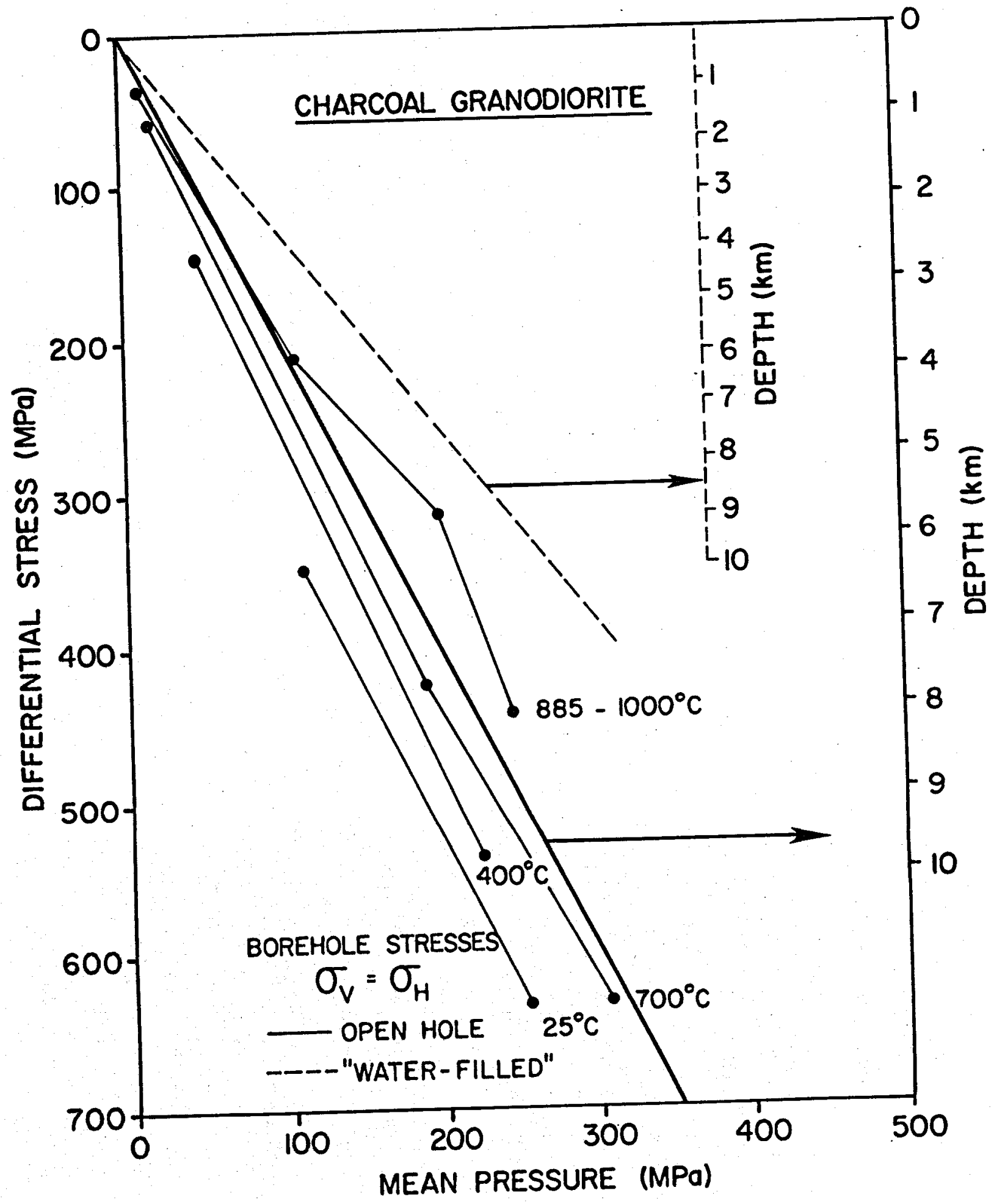

Figure 25. Assessment of borehole stability for dry Charcoal Granodiorite. 


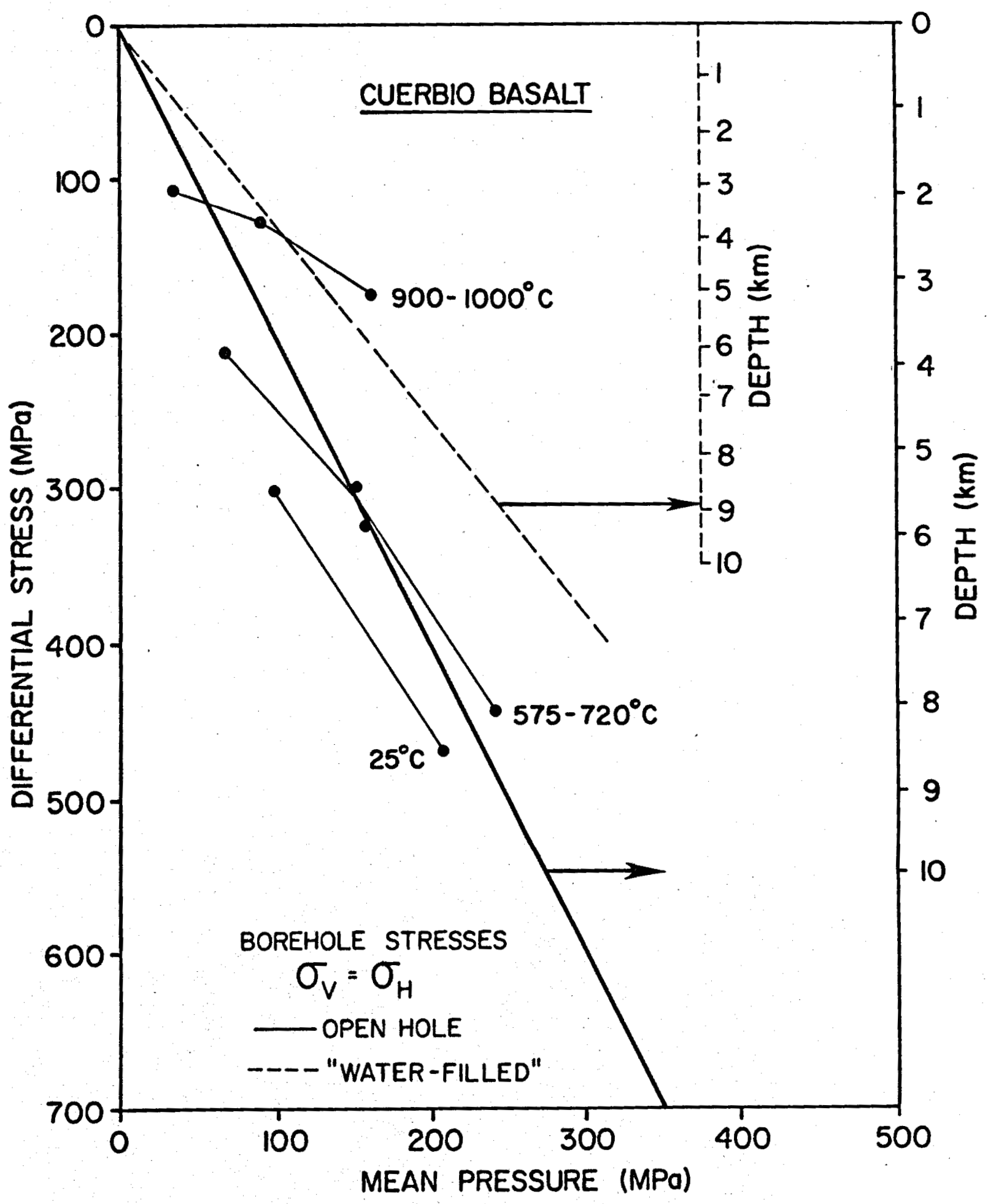

Figure 26. Assessment of borehole stability for dry Cuerbio Basalt. 
TABLE 9- MAXIMUM DEPTH (KM) OF A STABLE BOREHOLE BASEO ON STRENGTH AND MEAN STRESS. DATA FOR DRY ROCKS

\begin{tabular}{|c|c|c|c|c|c|c|c|}
\hline \multicolumn{3}{|c|}{ CONOITIONS } & $\sigma_{h} / \sigma_{v}$ & $25^{\circ} \mathrm{C}$ & $400^{\circ} \mathrm{C}$ & $700^{\circ} \mathrm{C}$ & $>900^{\circ} \mathrm{C}$ \\
\hline \multirow{4}{*}{ 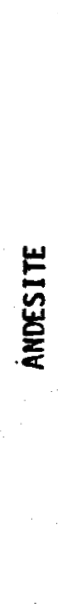 } & \multirow{2}{*}{ 宅 } & $\begin{array}{l}\text { OPEN } \\
\text { HOLE }\end{array}$ & $\begin{array}{l}2.0 \\
1.0 \\
0.5\end{array}$ & $\begin{array}{r}2 * \\
5 \\
>10\end{array}$ & $\begin{array}{r}2 \\
4 \\
>10\end{array}$ & $\begin{array}{r}1 \\
3 \\
>10\end{array}$ & $\begin{array}{l}1 \\
2 \\
4\end{array}$ \\
\hline & & $\begin{array}{l}\text { FILLED } \\
\text { HOLE }\end{array}$ & $\begin{array}{l}2.0 \\
1.0 \\
0.5\end{array}$ & $\begin{array}{r}4 \\
>10 \\
>10\end{array}$ & $\begin{array}{r}3 \\
>10 \\
>10\end{array}$ & $\begin{array}{r}2 \\
>10 \\
>10\end{array}$ & $\begin{array}{r}1 \\
>10 \\
>10\end{array}$ \\
\hline & \multirow{2}{*}{ 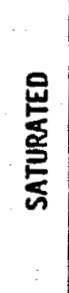 } & $\begin{array}{l}\text { OPEN } \\
\text { HOLE }\end{array}$ & $\begin{array}{l}2.0 \\
1.0 \\
0.5\end{array}$ & $\begin{array}{r}2 \\
9 \\
>10\end{array}$ & $\begin{array}{r}2 \\
7 \\
>10\end{array}$ & $\begin{array}{r}1 \\
5 \\
>10\end{array}$ & $\begin{array}{r}1 \\
3 \\
>10\end{array}$ \\
\hline & & $\begin{array}{l}\text { FILLED } \\
\text { HOLE }\end{array}$ & $\begin{array}{l}2.0 \\
1.0 \\
0.5\end{array}$ & $\begin{array}{r}5 \\
>10 \\
*\end{array}$ & $\begin{array}{r}4 \\
>10 \\
+\end{array}$ & $\begin{array}{r}3 \\
>10 \\
* *\end{array}$ & $\begin{array}{r}2 \\
>10 \\
* *\end{array}$ \\
\hline \multirow{4}{*}{ 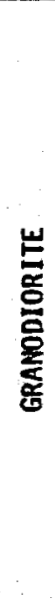 } & \multirow{2}{*}{ 产 } & $\begin{array}{l}\text { OPEN } \\
\text { HOLE }\end{array}$ & $\begin{array}{l}2.0 \\
1.0 \\
0.5\end{array}$ & $\begin{array}{r}7 \\
>10 \\
>10\end{array}$ & $\begin{array}{r}4 \\
>10 \\
>10\end{array}$ & $\begin{array}{r}1 \\
>10 \\
>10\end{array}$ & $\begin{array}{r}1 \\
2 \\
>10\end{array}$ \\
\hline & & $\begin{array}{l}\text { FILLED } \\
\text { HOLE }\end{array}$ & $\begin{array}{l}2.0 \\
1.0 \\
0.5\end{array}$ & $\begin{array}{l}>10 \\
>10 \\
>10\end{array}$ & $\begin{array}{l}>10 \\
>10 \\
>10\end{array}$ & $\begin{array}{r}6 \\
>10 \\
>10\end{array}$ & $\begin{array}{r}1 \\
>10 \\
>10\end{array}$ \\
\hline & 올 & $\begin{array}{l}\text { OPEN } \\
\text { HOLE }\end{array}$ & $\begin{array}{l}2.0 \\
1.0 \\
0.5\end{array}$ & $\begin{array}{r}6 \\
>10 \\
>10\end{array}$ & $\begin{array}{r}2 \\
>10 \\
>10\end{array}$ & $\begin{array}{r}1 \\
>10 \\
>10\end{array}$ & $\begin{array}{l}1 \\
2 \\
4\end{array}$ \\
\hline & $\underset{E}{E}$ & $\begin{array}{l}\text { FILLED } \\
\text { HOLE }\end{array}$ & $\begin{array}{l}2.0 \\
1.0 \\
0.5\end{array}$ & $\begin{array}{l}>10 \\
>10 \\
*\end{array}$ & $\begin{array}{r}>10 \\
>10 \\
\star *\end{array}$ & $\begin{array}{r}>10 \\
>10 \\
* \star\end{array}$ & $\begin{array}{r}2 \\
>10 \\
* *\end{array}$ \\
\hline & 2 & $\begin{array}{l}\text { OPEN } \\
\text { HOLE }\end{array}$ & $\begin{array}{l}2.0 \\
1.0 \\
0.5\end{array}$ & $\begin{array}{r}4 \\
>10 \\
>10\end{array}$ & $\begin{array}{c}- \\
- \\
>10\end{array}$ & $\begin{array}{r}2 \\
6 \\
>10\end{array}$ & $\begin{array}{l}1 \\
2 \\
4\end{array}$ \\
\hline$\Xi$ & & $\begin{array}{l}\text { FILLED } \\
\text { HOLE }\end{array}$ & $\begin{array}{l}2.0 \\
1.0 \\
0.5\end{array}$ & $\begin{array}{l}>10 \\
>10 \\
>10\end{array}$ & $\begin{array}{l}>10 \\
>10\end{array}$ & $\begin{array}{r}4 \\
>10 \\
>10\end{array}$ & $\begin{array}{r}1 \\
5 \\
>10\end{array}$ \\
\hline 这 & 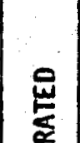 & $\begin{array}{l}\text { OPEN } \\
\text { HOLE }\end{array}$ & $\begin{array}{l}2.0 \\
1.0 \\
0.5\end{array}$ & $\begin{array}{r}4 \\
>10 \\
>10\end{array}$ & 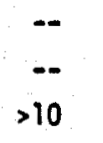 & $\begin{array}{r}3 \\
9 \\
>10\end{array}$ & $\begin{array}{l}1 \\
3 \\
7\end{array}$ \\
\hline ' & $\frac{E}{n}$ & $\begin{array}{l}\text { FILLED } \\
\text { HOLE }\end{array}$ & $\begin{array}{l}2.0 \\
1.0 \\
0.5\end{array}$ & $\begin{array}{r}>10 \\
>10 \\
\end{array}$ & $\begin{array}{l}\cdots \\
>10 \\
\end{array}$ & $\begin{array}{r}5 \\
>10 \\
\star *\end{array}$ & $\begin{array}{r}2 \\
>10 \\
\star \star\end{array}$ \\
\hline
\end{tabular}


stability. This far-field stress condition is most likely to occur in regions affected by horizontal extension of the crust.

5. For impervious, saturated rock with filled boreholes where $\sigma_{h} / \sigma_{v}$ is 0.5 the tangential borehole stress is actually tensile increasing at $-3 \mathrm{MPa} / \mathrm{km}$. This would tend to favor tensile failure at a few kilometers depth; accordingly, no corresponding depths are indicated in Table 9. However, the gradient of borehole stresses for this condition (Table 8, $\left(\sigma_{1}-\sigma_{3}\right)=20 \mathrm{MPa} / \mathrm{km}$ and $\left.\sigma_{\mathrm{m}}=8 \mathrm{MPa} / \mathrm{km}\right)$ constitute a "worst case" that is utilized below for evaluation of the water-saturated results. Thus, a $\sigma_{h} / \sigma_{v}$ ratio of 0.5 is the most favorable case for stability in dry rocks and the least favorable one for wet ones.

These predictions are likely to be optimistic. Recall that the borehọle stresses would be higher than supposed if the far-field horizontal stresses were not equal and if the stress concentrations in a real roughsurfaced hole were greater than those idealized for the calculations. Furthermore, we have not yet fully accounted for the effects of pore water (see below) and time. On the other hand superposed thermoelastic stresses from cooled boreholes in hot rock would diminish borehole stress differences and enhance stability.

We have emphasized the testing of room-dry rocks at a strain rate of $10^{-4} / \mathrm{s}$ because data can be collected quickly and easily. Moreover the dry tests may be valid similations of in situ conditions if "dry-out" zones exist immediately above buried magma chambers and if drilling is accomplished without water. The results are conservative in the sense that the measured strength is the highest and ductility is the lowest that can be expected. In other words, if a borehole in dry rock is potentially 
unstable under short-time loading, then it will surely fail under longterm loading or where the rock has been water-weakened.

Water-Saturated Rocks. If dry-out zones are not present in the roofrocks of buried magma chambers, the pores, grain boundaries, cracks, and macrofractures will be water-saturated. Moreover, water may be used in the drilling process and to cool the borehole walls. The influence of water on rock strength is two-fold. The purely mechanical effect is to reduce the effective borehole stresses (Table 6), according to Terzaghis principle (Handin et al., 1963; Brace and Martin, 1968), and to extend somewhat the maximum depth of the stable field (Table 9). On the other hand, chemical effects involve hydration of the silanol bonds in silicates. The higher is the temperature, the more significant is this phenomenon likely to be (Griggs, 1967). Water-weakening can occur due to (a) chemisorption or stress corrosion effects at crack tips that reduce fracture strengths (e.g., see review by Anderson and Grew, 1977), (b) lowered melting points, and (c) lowering of the critical resolved shear stresses for dislocation gliding, i.e., yield strengths for crystal plastic mechanisms (e.g., Griggs and Blacic, 1965; Griggs, 1974; Balderman, 1974; Tullis, 1979). Without detailed thin section and perhaps TEM studies (scheduled for future work), it is not possible to say which of these mechanisms has produced the reduced strength of the andesite at elevated temperatures demonstrated above. But, it is generally recognized that $\mathrm{H}_{2} \mathrm{O}$ must gain access to the crystal surfaces (item $a$, above) and then to their substructures (items $b$ and $c$, above) to effect the hydrolytic weakening. It is not surprising therefore, that of the three rocks tested, the andesite shows the greatest weakening (Figures 6,7 , and 8 ) as its relatively 
large porosity (10-12 percent) permits greater access of the pore water to the solid interfaces.

In the ductile regime it has been recognized that there is a temperature effect on the water-weakening of quartz (Griggs, 1967; Balderman, 1974). Our temperatures are much in excess of these temperatures (300$500^{\circ} \mathrm{C}$ ). More recently however, it has been shown that there also is a pressure effect, as water is driven from the surface of pores and cracks into the adjacent crystal structures with increases pressure (Tullis, 1979). Our pore pressures 50 and $100 \mathrm{MPa}$ are small compared to those (1000 and $1500 \mathrm{MPa}$ ) needed in the laboratory to recognize this effect (Tultis and Yund, 1978). Thus, al though our temperatures are more than sufficient, our pressures may be too low to foster the ductile aspect of water weakening (item $c$, above). Coupling this view with the brittle response and macroscopic appearance of the specimens, we tentatively conclude that the water weakening of the andesite is a stress corrosion and/or reduced mel ting-temperature effect.

Borehole stability for wet andesite and granodiorite is estimated using borehole stress loci for impervious, saturated rocks and the assumptions that $\sigma_{h} / \sigma_{v}$ is 0.5 and 1.0 and that the effective pressure in the rock is zero (Figures 27 and 28 ). As noted above, the ratio of 0.5 presents a "worst case" condition and involves the development of tangential tensile stress. Failure in tension with the development of vertical fractures oriented radially to the borehole is a distinct possibility under these conditions at a few kilometers depth. Such failure would not cause borehole collapse, but it would lead to the loss of drilling fluids. 


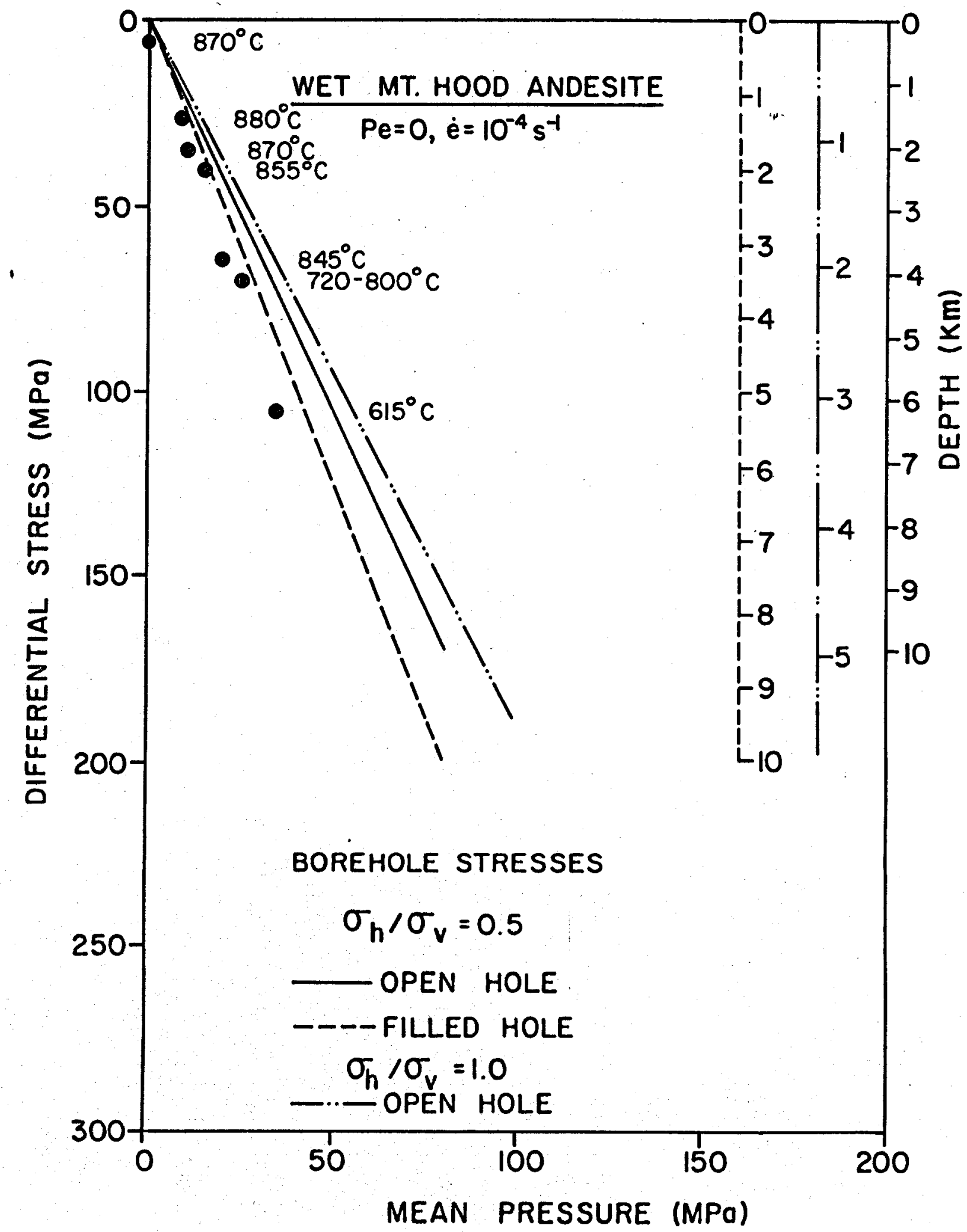

Figure 27. Assessment of borehole stability for water-wet Mt. Hood Andesite at zero effective pressure. Temperatures correspond to data points located to the left. Deviation from a linear $3: 1$ trend is do solely to rounding strength data to the nearest $5 \mathrm{MPa}$. Note three borehole stress conditions and corresponding depth scales are given. 


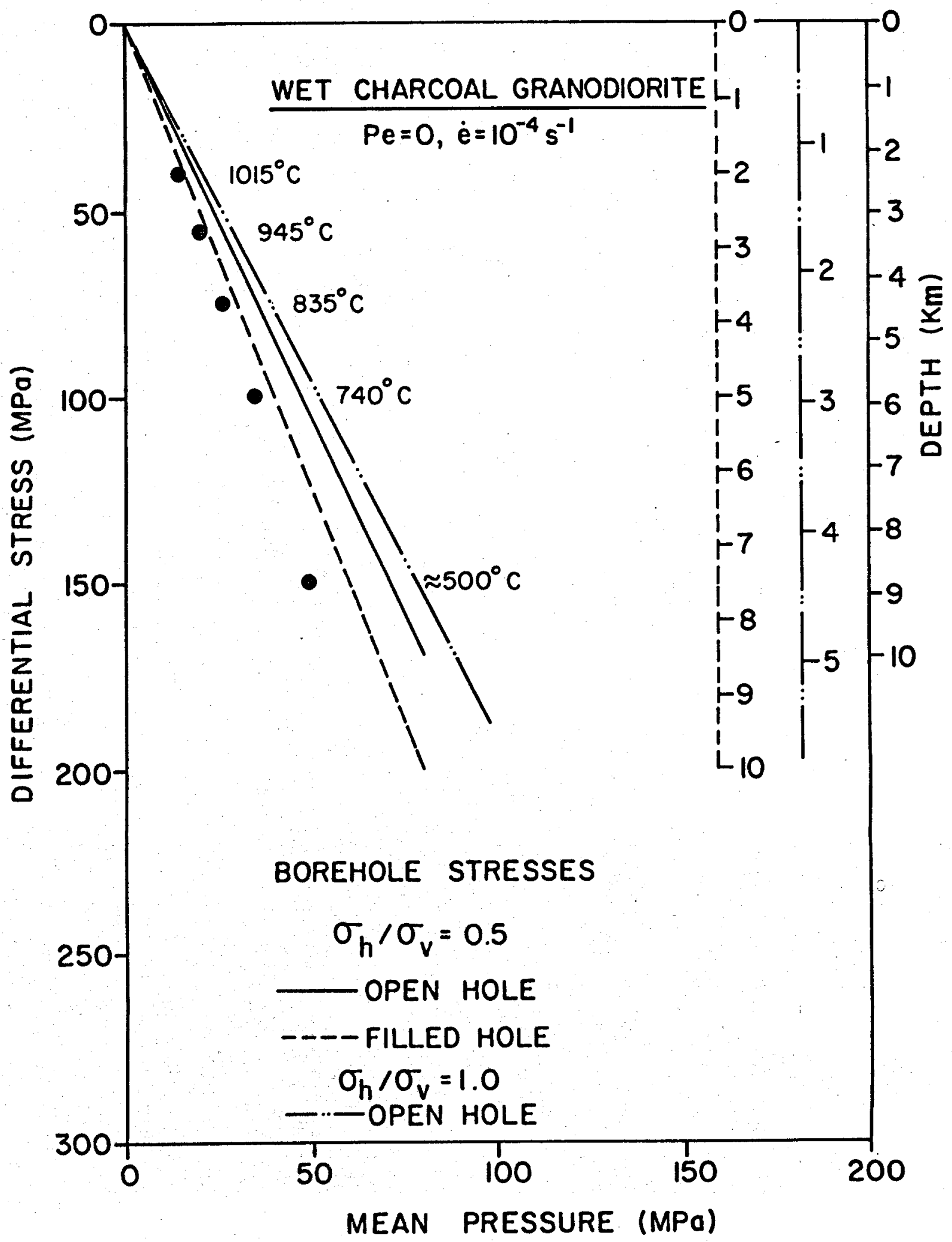

Figure 28. Assessment of borehole stability in water-wet Charcoal Granodiorite at zero effective pressure. Details are the same as for Figure 27. 
Below we ignore this type of failure, and assume that the rocks will fail in compressive shear fractures according to the differential stress-mean stress relationship. The $\sigma_{h} / \sigma_{v}$ ratio of 1.0 , and a corresponding open hole condition, also is shown. in Figures 27 and 28 to permit comparison with data for the dry rock in that we find water-weakening of the andesite is appreciable at temperatures above $800^{\circ} \mathrm{C}$ (Figure 6).

Data points for both rocks lie very close to, but still to the left of the worst-case borehole-stress loci (Figures 27 and 28 ). These results suggest, conservatively, that borehole stability would require smooth borehole walis no hotter than $600^{\circ} \mathrm{C}$. At higher temperatures the data are too close to the borehole-stress loci to predict stability. Indeed at $850-900^{\circ} \mathrm{C}$ failure is 1 ikely at depths $\leq 1 \mathrm{~km}$ for the andesite, and at $\leq 3$ $\mathrm{km}$ for the granodiorite if at 900 to $1000^{\circ} \mathrm{C}$. On the other hand, even though the andesite is weakened by the water, it would appear that it would sustain stable boreholes in open holes to depths $\geq 10 \mathrm{~km}$ and temperatures to $880^{\circ} \mathrm{C}$ if the effective pressure were zero and $\sigma_{h}=\sigma_{v}$.

Time Effects. Thus far we have dealt solely with instantaneous compressive strengths of the crystalline rocks. Corresponding predictions of borehole stability involve possible shear failure upon or shortly after penetration by the drill. Such failures could lead to stuck drills and subsequent loss of the hole, and thus are significant to the borehole stability problem. This does not speak, however, to the additional problem of borehole maintenance over the multiyear life of a successful magmaenergy-extraction well. It is well known that lowering the strain rate or increasing the duration of loading in a creep test decreases strength (e.g., Carter and Kirby, 1978). The higher is the temperature, the stronger is the time dependence, especially with approach to the melting point. 
Only a few studies of time-dependent deformation of crystalline rocks have been made at low pressures and elevated temperatures (see recent review by Carter et al., 1981). There is the unconfined uniaxial-compression creep testing of Murrell and Chakravarty (1973) on crystalline rocks to partial melting, that of Rummel (1969) on a granite at temperatures of 100 to $400^{\circ} \mathrm{C}$, and that of Goetze (1971) on Westerly Granite to temperatures of melting at $500 \mathrm{MPa}$ confining pressure and $100 \mathrm{MPa}$ pore-fluid pressure. A compilation of their data and that of Carter et al. (1981) at higher confining pressure is given in Table 10 (Carter et al., 1981, Table 2). In each study the data are empirically well fit by the equation shown in Table 10. Corresponding plots of $\log$ creep strain $\left(\varepsilon_{t}\right)$ versus time $(\log t, s)$ for temperatures to $600^{\circ} \mathrm{C}$ and differential stresses of 10 and $100 \mathrm{MPa}$ (Figure 29, Carter et a1., 1981, Figure 13) show that for durations up to say 10 years (1ife expectancy of a geothermal well) the creep strains are small $\left(10^{-2}\right.$ to $\left.10^{-4}\right)$. While this is an encouraging result relative to the borehole stability problem much work remains systematically to evaluate time-dependent flow at realistic conditions and with other rock types and to evaluate the validity of corresponding constitutive equations. 
Table 10. TRANSIENT CREEP PARAMETERS FOR GRANITIC ROCKS 5

\begin{tabular}{|c|c|c|c|c|c|c|c|c|}
\hline \multirow{2}{*}{ Material } & \multirow{2}{*}{$\begin{array}{l}\text { Temperature } \\
\text { Range }\left({ }^{\circ} \mathrm{C}\right)\end{array}$} & \multirow{2}{*}{$\begin{array}{l}\text { Effective } \\
\text { Pressure (MPa) }\end{array}$} & \multirow[b]{2}{*}{ Stress (MPa) } & \multicolumn{4}{|c|}{$\varepsilon_{t}=\beta_{0} \sigma^{n_{t} m} \exp (-E / R T)$} & \multirow[b]{2}{*}{ Source } \\
\hline & & & & $B_{0}{ }^{\dagger}$ & $\mathbf{n}$ & $\mathrm{m}$ & $\mathrm{E}(\mathrm{kJ} / \mathrm{mole})$ & \\
\hline Granite & $20-400$ & 0 & 87 & $2 \times 10^{-6}$ & $1.35 *$ & $0.25 *$ & 6 & Rürmel [1969] \\
\hline Granite & 711 & 400 & 64 & 3.9 & 1.7 & 0.49 & 159 & Goetze [1971] \\
\hline Granite & $600-800$ & 1000 & $600-1200$ & $7 \times 10^{-5}$ & 2.2 & 0.51 & 128 & This study \\
\hline Granodiorite & $830-1045$ & 0 & 100 & $3 \times 10^{2}$ & 1 & 0.37 & 176 & $\begin{array}{l}\text { Murre11 and Che'kravarty, } \\
1973 ; \\
\text { Murre11, } 1976\end{array}$ \\
\hline
\end{tabular}

\$ Copy of Table 2 in Carter et al. (1981)

$+\beta_{0}$ is calculated for longitudinal differential stress expressed in $\mathrm{MPa}$ and time in seconds.

* These values are of doubtful significance as the material deformed dominantly by logarithmic creep. 

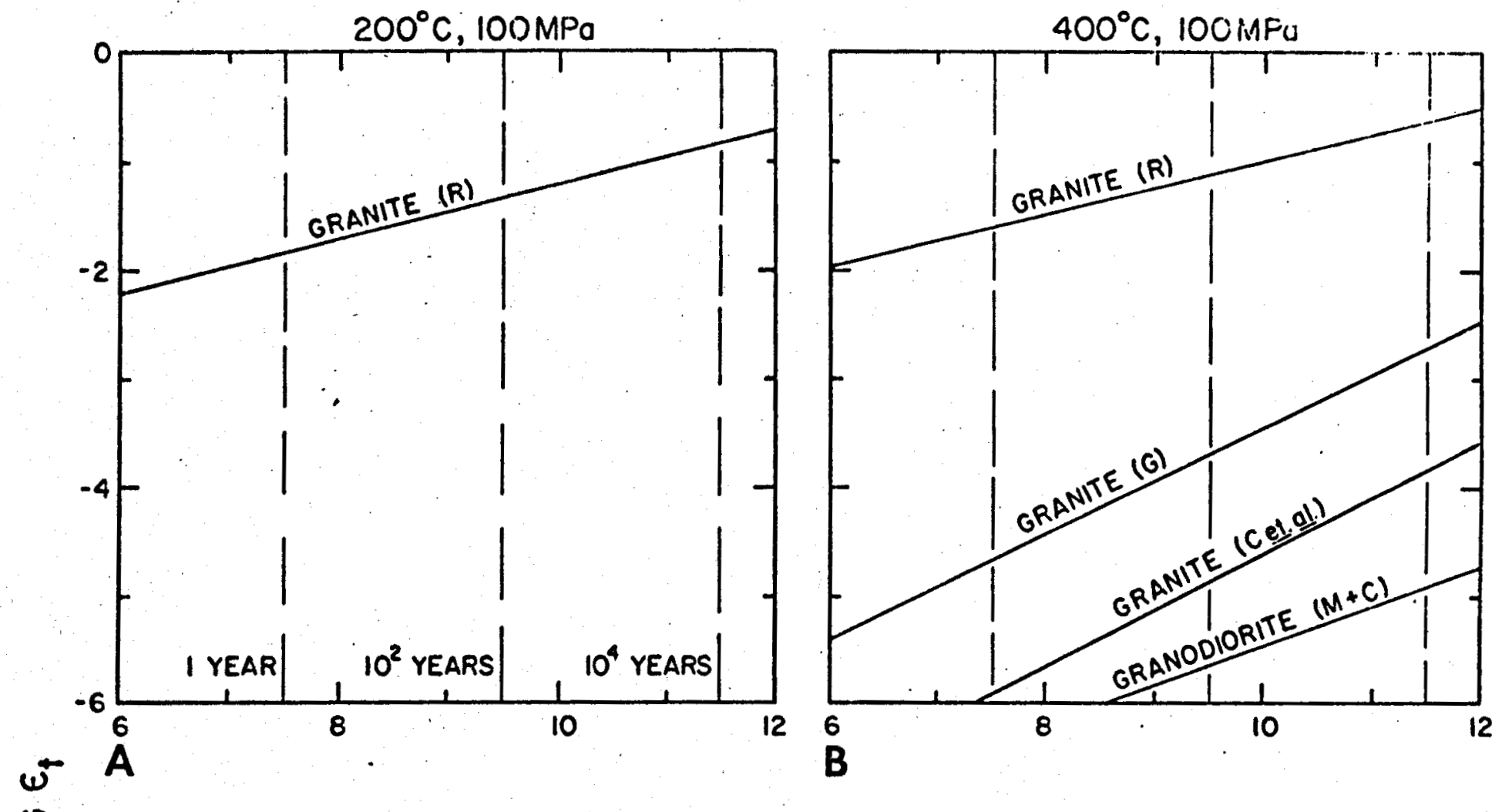

$\stackrel{20}{9}$
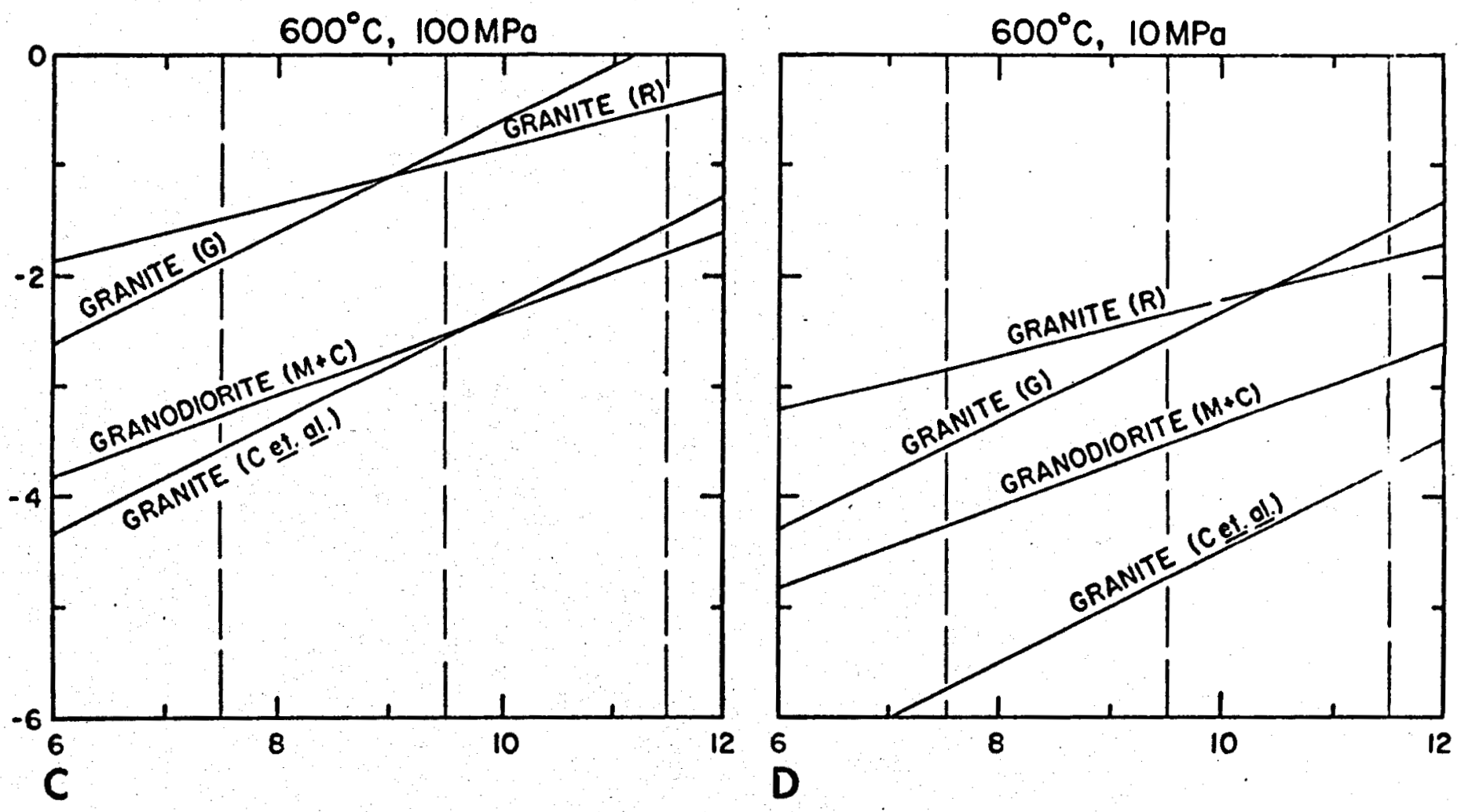

LOG I (seconds)

Figure 29. Extrapolation in log strain - log time space of power-law hightemperature transient creep equation and parameters given in Table 10.

(R) Rummel (1969), (G) Goetze, 1971), (M\&C) Murrell and Chakravarty (1973), and ( $C$ et al.) Carter et al.(1981). Figure is courtesy of Carter and coworkers. 


\section{CONCLUSIONS}

The major conclusions to be drawn from the experimental and petrofabric results now available are as follows:

1) The ultimate compressive strengths of the dry crystalline rocks decrease gradually with increasing temperature to about $900^{\circ} \mathrm{C}$, and then more rapidly as partial melting is approached at between $1000^{\circ}$ and $1100^{\circ} \mathrm{C}$. The strengthening effect of increasing effective confining pressure diminishes with increasing temperature. The obsidian is even stronger than are the crystalline rocks up to $600^{\circ} \mathrm{C}$, above which, however, the glass softens and its strength vanishes at $800^{\circ} \mathrm{C}$.

2) There is pronounced water-weakening only of the Mt. Hood Andesite and that occurs between $850^{\circ}$ and $880^{\circ} \mathrm{C}$ (zero effective pressure). At $870^{\circ}-880^{\circ} \mathrm{C}$ its ultimate strength is only 5 to $25 \mathrm{MPa}$ compared to an average room-dry strength of $75 \mathrm{MPa}$ at $1000^{\circ} \mathrm{C}$. The Cuerbio Basalt may be weakened slightly between $800^{\circ}$ and $900^{\circ} \mathrm{C}$, but the Charcoal Granodiorite is unaffected by the presence of water to $1000^{\circ} \mathrm{C}$.

3) The crystalline rocks are essentially brittle throughout the pressure and temperature ranges explored until partial melting occurs. They deform primarily by fracture, with some ductile flow in the groundmass where it is present, particularly adjacent to faults, some gliding flow (kinking) in the biotite, and thermal alteration of biotite, hornblende and pyroxene contributing to the strength reduction by an unknown, but probably minor amount. Shortenings at failure are $\leq 3$ percent in roomdry tests and $\leq 1$ percent in wet ones. Virtually all the permanent shortening is ascribable to macroscopic faulting. 
4) At confining pressures to $100 \mathrm{MPa}$ the degradation of strength and continued brittle behavior with increasing temperature suggest that the crystalline rocks will be drillable by conventional methods up to temperatures of partial melting. In fact, rapid decreases in strength at the highest temperatures suggest that the penetration rate ought to increase as the roof rock-magma interface is approached.

5) Several facts strongly suggest that the temperature-weakening of the room dry crystalline rocks is due to intrinsic effects of temperature on the processes leading to macroscopic shear fracturing (or faulting), and not merely to degradation of strength by thermal cracking, at least when the rocks are subjected to confining pressure. (1) Brittle fracture accounts for virtually all the permanent strain. (2) The degree of microfracturing associated with the mechanical loading, as distinguished from the thermoelastic stressing, is about the same at all temperatures from $25^{\circ}$ to $1000^{\circ} \mathrm{C}$. (3) Specimens heated to $900^{\circ} \mathrm{C}$, cooled, and then deformed at $25^{\circ} \mathrm{C}$ are at least as strong as those that have not been preheated.

On the other hand, similar thermal cycling greatly degrades the strengths of the unconfined rocks, presumably because the effect of the thermal cracks on subsequent failure is not suppressed by confining pressure; that is, heating significantly modifies the mechanical state of the material. Thus, data from unconfined tests alone cannot be used for valid predictions of rock properties under in situ conditions, particularly for geological or geophysical applications. However, such tests may be useful to estimate strengths during drilling where essentially unconfined conditions and rapid cooling may obtain. 
Several workers have regarded fracturing as a thermally-activated process, and by fitting their data to an equation of the form of equation 4, they have derived an apparent activation energy (see Carter and Kirby, 1978). Owing to the lack of data on time effects, we cannot do so. However, even if brittle fracturing is indeed rate-controlled, how could we, or the previous workers for that matter, associate the purely empirical, apparent activation energy with a specific process? Is it the initiation and/or propagation of intragranular microfracturing? Is it grainboundary sliding? Is it the condensation of microfracturing in preferred zones and/or the precursory coalescence that appears to cause the instability manifest in the macroscopic fracturing, stress drop, and worksoftening that characterize the ultimate failure of these rocks? We claim that a lot more research on fracture must be done before a meaningful constitutive "law" can be written for inelastic deformations in the brittle state.

6) Water-weakening in the andesite, in light of its dominantly brittle behavior, probably is caused by hydrolytic weakening of silanol bonds in the silicate minerals which promotes stress-corrosion cracking and reduces melting temperatures. The andesite, rather than the basalt or granodiorite, is water-weakened probably because its greater porosity (10 to 12 percent) permits more pervasive contact between water and solid internal surfaces than in the other two rocks.

7) Because the deformations of the rocks are essentially cataclastic at all temperatures, we suppose that boreholes in these rocks will fail in shear when the differential stress reaches the ultimate compressive strength for a given mean stress. In general, the maximum depth for stable 
boreholes increases with decreasing temperature, and decreasing $\sigma_{h} / \sigma_{v}$; and for dry rocks, filled boreholes are more stable than open ones. Further, for similar conditions boreholes in granodiorite will be stable to greater depths than those in basalt or andesite, with the later providing the least stable ones. Assessment of stability for a given rock type is, therefore, primarily a function of assumed or known borehole stress and temperature conditions. For examples: for $\sigma_{h} / \sigma_{v}$ of 1.0, filled boreholes (medium with specific gravity of 1.0) in dry impermeable rock are apt to be stable to $>10 \mathrm{~km}$ even at temperatures of $900^{\circ} \mathrm{C}$ or higher. On the other hand, in open boreholes and the same stress ratio, boreholes in dry andesite are likely to fail at 2, 3, 4, or $5 \mathrm{~km}$ depth for temperatures of $900^{\circ}, 700^{\circ}, 400^{\circ}$, and $25^{\circ} \mathrm{C}$, respectively. For dry rocks, the $\sigma_{h} / \sigma_{v}$ ratio of 0.5 provides the greatest stability of the three ratios considered, but for water-saturated rocks and filled boreholes this same ratio provides a "worst-case" condition because the tangential borehole stress becomes tensile. Accordingly, stability of filled boreholes in saturated rocks would require smooth walls and temperatures no hotter than $600^{\circ} \mathrm{C}$. On the other hand, even though the andesite is weakened by water at high temperature, it should sustain stable boreholes in open holes to depths $>10 \mathrm{~km}$ and temperatures to $880^{\circ} \mathrm{C}$ if the effective pressure is zero and $\sigma_{h} / \sigma_{v}$ is 1.0 .

Our predictions of borehole stability are optimistic because we have not accounted for stress concentrations due to irregularities in the borehole walls, the frictional sliding strength of pre-existing fractures intersecting the borehole and dangerously inclined to the borehole stresses, or the kinetics of water-weakening. Moreover, we have focussed initially 
on the instantaneous strengths and ductilities of the rocks with borehole stability predictions pertinent only to relative short periods of time immediately after penetration by the drill. On the other hand, long term stability of the boreholes seems probable, at least in light of the few time-dependent strength data avaflable in the literature. However, data under appropriate conditions are meager and pertinent testing has just begun. Also we have not considered the influence of thermoelastic stresses that would develop around cooled boreholes and that upon superposition would tend to stabilize the borehole. Predictions must remain qualitative until sophisticated numerical methods can be applied to the problem. 


\section{ACKNOWLEDGMENTS}

We wish to thank the Sandia Laboratories, particularly J. L. Colp, H. M. Stoller, and R. K. Traeger, and the members of Sandia's Magma Energy Extraction Advisory Panel, and G. A. Kolstad, U.S. Department of Energy for encouragement and continued support of this work (Contract No. 13-2242). Special thanks go to E. J. Graeber, Sandia Laboratories, for collection of our starting blocks of Mt. Hood Andesite, Newberry Rhyolite Obsidian, and Cuerbio Basalt, for supplying X-ray photos of the vesicular basalt, and along with $P$. F. Hlava for the microprobe analyses of the glasses in partially melted andesite and granodiorite. We could not have carried on this experimental program without the help in apparatus design, fabrication and maintenance of J. M. Logan and J. N. Magouirk, Center for Tectonophysics, Texas A\&M University. We thank N. L. Carter and his co-

workers (1981) for permission to use their Table 2 and Figure 13 as our Table 10 and Figure 29. 


\section{REFERENCES}

Anderson, 0. L. and Grew, P. C., 1977, Stress corrosion theory of crack propagation with applications to geophysics: Reviews of Geophys. and Space Phys., 15, 77-104.

Balderman, M. A., 1974, The effect of strain rate and temperature on the yield point of hydrolytically weakened synthetic quartz: J. Geophys. Res., 79, 1647-1652.

Borg, Iris and Handin, John, 1966, Experimental deformation of crystalline rocks: Tectonophysics, $\underline{3}, 249-368$.

Brace, W. F. and Martin, R. J., III, 1968, A test of the law of effective stress for crystali ine rocks of low porosity: Int. J. Rock Mech. Min. Sci., 5, 415-426.

Brown, D. W., 1976, Personal communication.

Carter, N. L., 1976, Steady state flow of rocks: Rev. Geophys. and Space Phys., 14, 301-357.

Carter, N. L. and Kirby, S. H., 1978, Transient creep and semibrittle behavior of crystalline rocks: Pure and Applied Geophys., 116, 806-839.

Carter, N. L., Anderson, D. A., Hansen, F. D., and Kranz, R. L., 1981, Creep and creep-rupture of granitic rocks: in The Handin Volume, American Geophysical Union, Geophysical Monograph Series, in press.

Conrad, R. E., II and Friedman, M., 1976, Microscopic feather fractures in the faulting process: Tectonophysics, 33, 187-193.

Friedman, M., 1975, Fracture in rock: Rev. Geophys. and Space Phys., 13, 352-358.

Friedman, M. and Bur, T. R., 1974, Investigation of the relations among residual strain, fabric, fracture, and ultrasonic attenuation and velocity in rocks: Int. J. Rock Mech. Min. Sci., 11, 221-234.

Friedman, M., Handin, J., Higgs, N. G., and Lantz, J. R., 1979, Strength and ductility of four dry igneous rocks at low pressures and temperatures to partial melting: 20th U.S. Symp. Rock Mech., 35-50, Austin, Tx., June.

Gay, N. C., 1975, In-situ stress measurements in southern Africa: Tectonophysics, $29, \overline{447-459}$.

Goetze, C., 1971, High temperature rheology of Westerly granite: J. Geophys. Res., 76, 1223-1230. 
Griggs, D. T., 1974, A model of hydrolytic weakening in quartz: J. Geophys. Res., 79, 1653-1661.

Griggs, D. T. and Blacic, J. D., 1965, Quartz: Anomalous weakness of synthetic crystals: Science, 147, 292-295.

Haimson, B. C., 1976, The hydrofracturing stress-measuring technique: Methods and recent field results in the United States: Proc. Int. Symp. on Investigation of Stress in Rock, Inst. Engr., Sydney, Australia, 23-30.

Haimson, B. C. and Voight, B., 1977, Crustal stress in Iceland: Pure and App1. Geophys., 115, 1-38.

Handin, J., 1966, Strength and ductility: Section 11 In: Handbook of Physical Constants, Rev. Ed., Geol. Soc. America Mem. 97, 223-289.

Handin, J. and Hager, R. V., Jr., 1957, Experimental deformation of sedimentary rocks under confining pressure: Tests at room temperature on dry samples: Am. Assoc. Petroleum Geologists Bul1., 41, $1-50$.

Handin, J., Hager, R. V., Jr., Friedman, M., and Feather, J. N., 1963, Experimental deformation of sedimentary rocks under confining pressure: Pore pressure tests: Am. Assoc. Petroleum Geologists, 47, 717-755.

Handin, J., Heard, H. C., and Magouirk, J. N., 1967, The effect of the intermediate principal stress on the failure of limestone, dolomite, and glass at different temperatures and strain rates: J. Geophys. Res., 72, 611-640.

Heard, H. C., 1963, Effect of large changes in strain rate in the experimental deformation of Yule Marble: J. Geol., 71, 162-195.

Krech, W. W., Henderson, F. A., and Hjelmstad, K. E., 1974, A standard rock suite for rapid excavation research: Bureau Mines, R.I. 7865, $29 \mathrm{p}$.

Lee, D. and Hart, E. W., 1971, Stress relaxation and mechanical behavior of metals: Metal1. Trans., 2, 1245-1248.

Lindholm, U.S., Yeakley, L. M., and Nagy, A., 1974, The dynamic strength and fracture properties of Dresser basait: Int. J. Rock Mech. Min. Sci., 11, 181-191.

Murase, T. and McBirney, A. F., 1973, Properties of some common igneous. rocks and their melts at high temperatures: Geol. Soc. Am. Bull., 84, 3563-3592. 
Murre11, S. A. F. and Chakravarty, S., 1973, Some new rheological experiments on igneous rocks at temperatures up to $1120^{\circ} \mathrm{C}$ : Geophys. $\mathrm{J}$. R. Astr. Soc., 34, 211-250.

Rürmmel, F., 1969, Studies of time dependent deformation of some granite and eclogite rock samples under uniaxial constant compressive stress and temperatures up to $400^{\circ} \mathrm{C}$ : Geofiz, $35,17-42$.

Rutter, E. H., Atkinson, B. K., and Mainprice, D. H., 1978, On the use of the stress relaxation testing method in studies of the mechanical behavior of geological materials: Geophys. J. R. Astro. Soc., 55(1), 155-170.

Tapponnier, P. and Brace, W. F., 1976, Development of stress-induced microcracks in Westerly Granite: Int. J. Rock Mech. Min. Sci., 12, 103-112

Timoshenko, S. P. and Goodier, J. N., 1970, Theory of Elasticity, New York, McGraw-Hill.

Tullis, J. A., 1979, High temperature deformation of rocks and minerals: Reviews of Geophys. and Space Phys., 17, 1137-1154.

Tullis, J. A. and Yund, R. A., 1978, Water weakening of experimentally deformed Westerly Granite: Trans. Am. Geophys. Union, 59, 376. 
DISTRIBUT ION :

Unlimited Release (UC66-212 copies)
4730 H. M. Stoller
4740 R. K. Traeger
4743
4743
5822
3141
3151
J. L. Colp (50)
H. C. Hardee (25)
E. J. Graeber
T. L. Werner
(5)
W. L. Garner (3) for DOE/TIC 